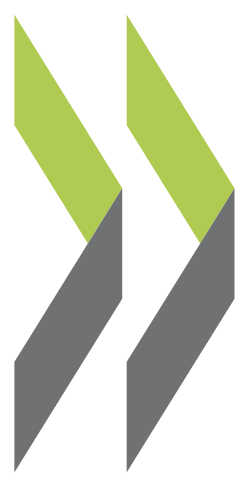

OECD Economics Department Working Papers No. 1420

Adapting to the changing labour market in New

\title{
David Carey
}

Zealand 
Organisation de Coopération et de Développement Économiques

Organisation for Economic Co-operation and Development

09-Oct-2017

ECONOMICS DEPARTMENT

English - Or. English

\section{ADAPTING TO THE CHANGING LABOUR MARKET IN NEW ZEALAND}

ECONOMICS DEPARTMENT WORKING PAPER No. 1420

\section{By David Carey}

OECD Working Papers should not be reported as representing the official views of the OECD or of its member countries. The opinions expressed and arguments employed are those of the author(s).

Authorised for publication by Alvaro Pereira, Director, Country Studies Branch, Economics Department.

All Economics Department Working Papers are available at www.oecd.org/eco/workingpapers. 
ECO Working Papers should not be reported as representing the official views of the OECD or of its member countries. The opinions expressed and arguments employed are those of the author(s).

Working Papers describe preliminary results or research in progress by the author(s) and are published to stimulate discussion on a broad range of issues on which the OECD works.

Comments on Working Papers are welcomed, and may be sent to OECD Economics Department, 2 rue André-Pascal, 75775 Paris Cedex 16, France, or by e-mail to eco.contact@oecd.org.

All Economics Department Working Papers are available at www.oecd.org/eco/workingpapers.

This document and any map included herein are without prejudice to the status of or sovereignty over any territory, to the delimitation of international frontiers and boundaries and to the name of any territory, city or area.

The statistical data for Israel are supplied by and under the responsibility of the relevant Israeli authorities. The use of such data by the OECD is without prejudice to the status of the Golan Heights, East Jerusalem and Israeli settlements in the West Bank under the terms of international law.

\section{(c) OECD (2017)}

You can copy, download or print OECD content for your own use, and you can include excerpts from OECD publications, databases and multimedia products in your own documents, presentations, blogs, websites and teaching materials, provided that suitable acknowledgment of OECD as source and copyright owner is given. All requests for commercial use and translation rights should be submitted to rights@oecd.org 


\section{ABSTRACT/RÉSUMÉ}

\section{Adapting to the Changing Labour Market in New Zealand}

Technological change is increasing the productivity of highly skilled workers but creating more challenging labour-market conditions for their low-skilled counterparts. These pressures are likely to grow, especially in light of progress being made in Artificial Intelligence. The NZ labour force is upskilling to meet these challenges, but more progress will be needed to keep ahead of the race with technology. Young New Zealanders will need to continue their education to higher levels than in the past and acquire skills that are more highly valued in the labour market. To maintain valuable skills, workers of all ages will need to engage more in lifelong learning. Some will need to retrain when their occupation becomes obsolete. Getting the most out of skills will also depend on allocating skills to their most productive uses. Reducing New Zealand's high rates of qualification and skills mismatches would boost both wages and productivity. With the possibility of more workers being displaced than in the past, greater efforts may need to be considered to help them get back into jobs.

This Working Paper relates to the 2017 OECD Economic Survey of New Zealand (www.oecd.org/eco/surveys/economic-survey-new-zealand.htm).

JEL classification: J24, J31, J62, J65, I25

Keywords: skill-biased technical change; polarisation; upskilling; education; lifelong learning; qualification and skills mismatches; reallocation; labour mobility; productivity; displaced workers

$* * * * *$

\section{S'adapter à l'évolution du marché du travail en Nouvelle-Zélande}

L'évolution technologique accroît la productivité des travailleurs très qualifiés, mais rend les conditions de travail plus difficiles pour leurs homologues peu qualifiés. Ces pressions sont appelées à s'intensifier, notamment compte tenu des progrès actuels de l'intelligence artificielle. En Nouvelle-Zélande, des efforts de relèvement des compétences de la main-d'œuvre sont en cours, mais des avancées supplémentaires seront nécessaires pour suivre le rythme de l'évolution technologique. Les jeunes Néo-Zélandais devront pousser leurs études plus loin qu'auparavant et acquérir les qualifications les plus recherchées sur le marché du travail. Pour entretenir des compétences utiles, les travailleurs de tous âges devront suivre des formations continues, et certains d'entre eux devront être requalifiés lorsque leur profession sera devenue obsolète. Pour bénéficier au mieux des compétences, il faudra aussi les affecter là où elles seront les plus productives. Réduire la forte inadéquation entre les qualifications et les compétences d'une part et le marché du travail d'autre part permettrait de faire progresser les salaires aussi bien que la productivité. Le risque de voir se multiplier les travailleurs licenciés pour raisons économiques étant sans doute plus fort dans l'avenir que dans le passé, il faudra envisager d'intensifier les efforts visant à les réintégrer sur le marché du travail.

Ce Document de travail se rapporte à l'Etude économique de l'OCDE de la Nouvelle-Zélande 2017 (www.oecd.org/fr/eco/etudes/etude-economique-nouvelle-zelande.htm).

Classification JEL : J24, J31, J62, I25

Mots clefs : changement technique axé sur les compétences ; «polarisation »; montée en gamme des compétences ; éducation ; l'apprentissage tout au long de la vie ; inadéquation des qualifications et des compétences ; réallocation ; mobilité des travailleurs ; productivité ; travailleurs licenciés pour raisons économiques 


\section{TABLE OF CONTENTS}

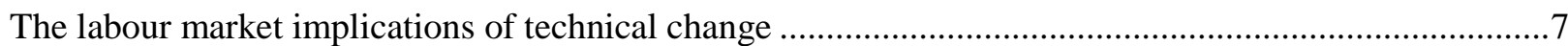

Employment is growing faster for high-skilled workers than for others...........................................

The supply of high-skilled workers is growing faster than the supply of others...................................10

Growth in supply of skills appears to have been well calibrated with non-cyclical growth in demand.14

The diffusion of digital technologies is expected to favour high-skilled workers .................................17

Many workers with disabilities will face more difficult labour market conditions................................19

Sole parents will also face more difficult labour market conditions .....................................................20

Digital technologies are facilitating the emergence of non-standard work arrangements......................21

Adapting to technical change that favours high-skilled workers ..........................................................22

NZ workers' strong information-processing skills should facilitate adjustment to technological

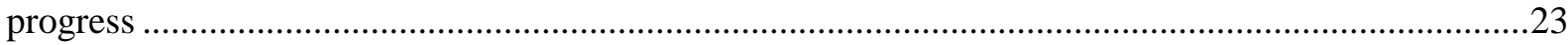

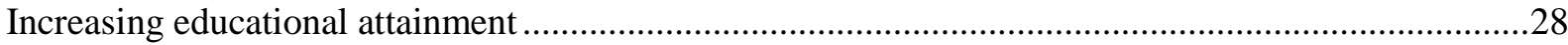

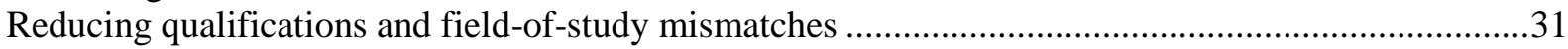

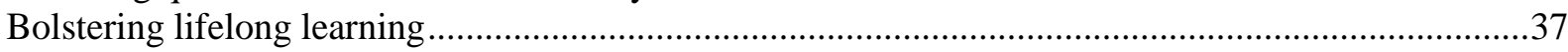

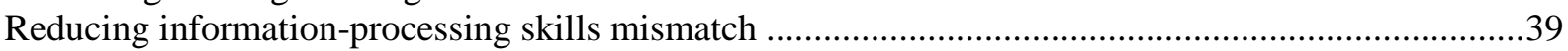

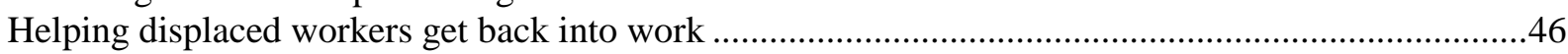

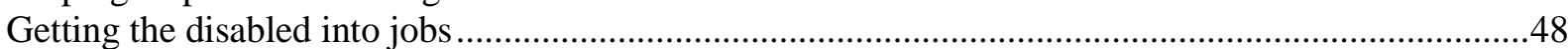

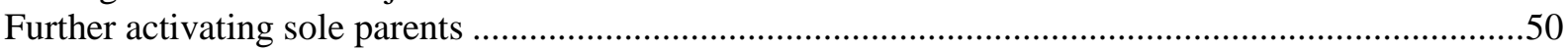

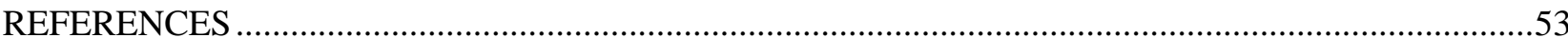

\section{Tables}

1. Levels and changes in occupational employment shares in New Zealand, 1991-2011 ........................9

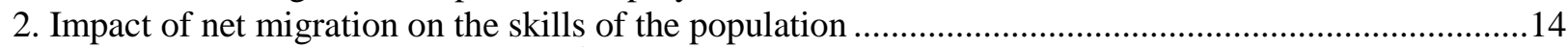

3. Earnings premiums for $\mathrm{NZ}$ workers ${ }^{1}$ by level of educational attainment ........................................15

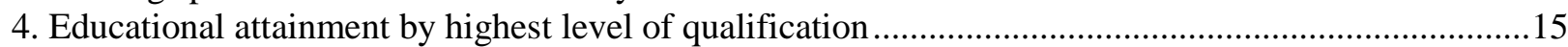

5. Employment, unemployment and inactivity rates by educational attainment and age group ...............15

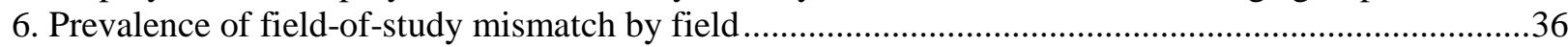

7. Mismatch and labour productivity in OECD countries: controlling for the overlap between the

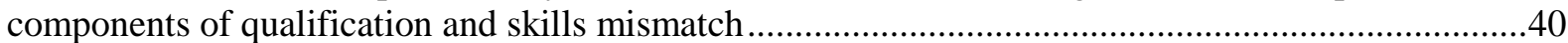

8. The effect of policy-related factors on skills mismatch .....................................................................

\section{Figures}

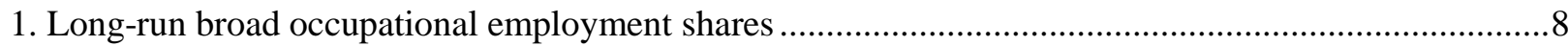

2. Job polarization: employment growth of occupations by computer use in the United States................10

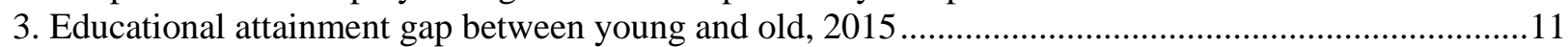

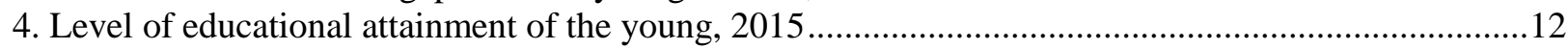

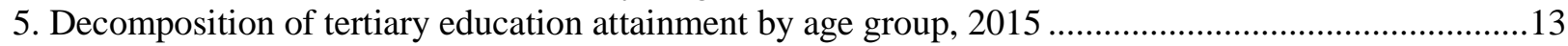

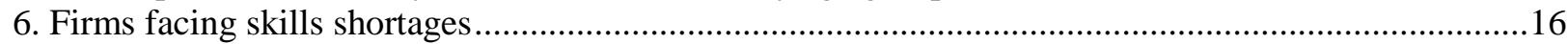

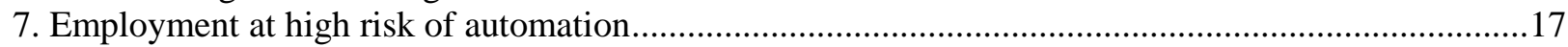

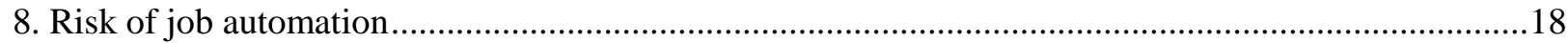

9. Share of NZ workers with high automation potential by education attainment and income level ........18

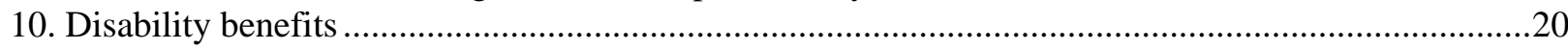




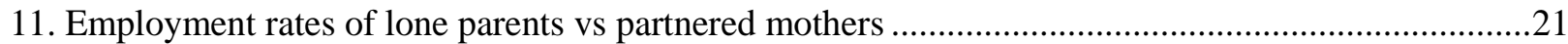

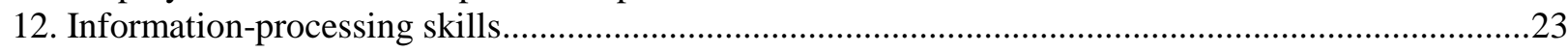

13. Proficiency in problem solving in technology-rich environments among adults...............................24

14. Return to numeracy skills across PIAAC countries ......................................................................24

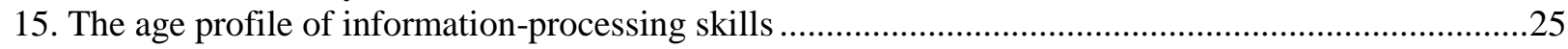

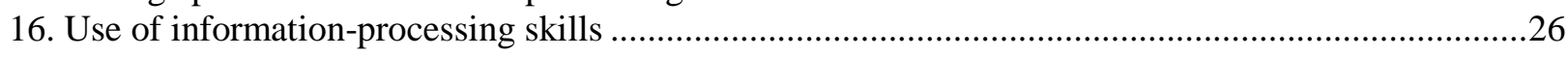

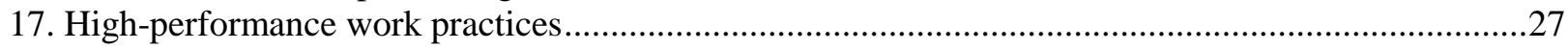

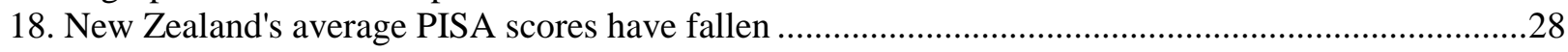

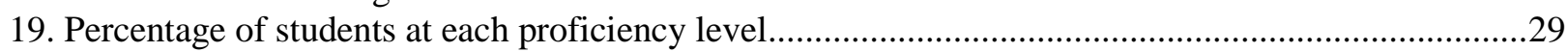

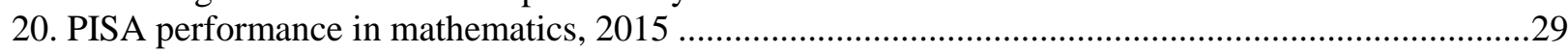

21. Influence of socio-economic background on PISA scores in mathematics .......................................30

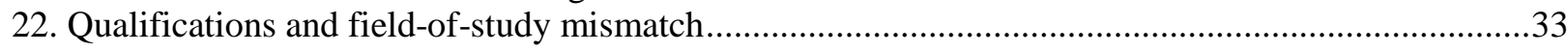

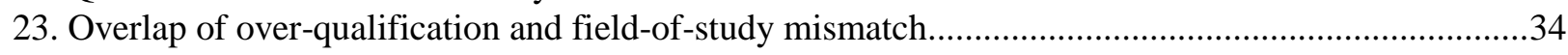

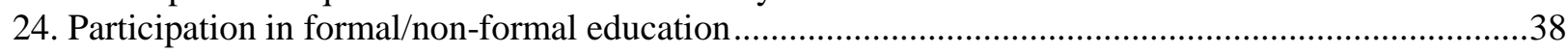

25 Percentage of workers with literacy skills mismatch ......................................................................

26. Counterfactual productivity gains from reducing skills mismatch ..................................................42

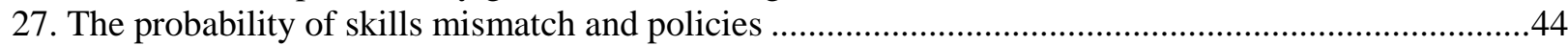

28. Estimated gains to labour productivity from adopting best practice policies to reduce skills

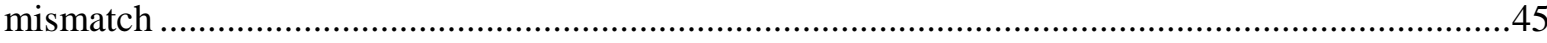

29 The notice period for individual dismissals in New Zealand is among the shortest .........................46

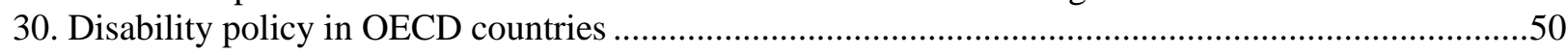

31. Effective tax rate for a sole parent moving to low-paid full-time work ...........................................51

\section{Boxes}

Box 1 Measuring qualifications, field-of-study and skills mismatches ..............................................32

Box 2. Skills mismatch, productivity and policies in New Zealand: evidence from PIAAC ....................42

Recommendations to enhance adaptation to the changing labour market ..............................................52 


\title{
ADAPTING TO THE CHANGING LABOUR MARKET IN NEW ZEALAND
}

\author{
by David Carey ${ }^{1}$
}

Technical progress is changing the labour market and, with advances in digitalisation, notably Artificial Intelligence (AI), may have even more profound effects in the not so distant future. Technical progress has increased the productivity of more-skilled workers, whose skills are complementary to new technologies, relative to low-skilled workers, and can be expected to continue to do so (Bessen, 2016). Low-skilled workers are likely to face increasingly challenging labour market conditions (Arntz et al., 2016). To hold down well paid jobs, workers will need to upskill, notably by acquiring skills that are in demand. For this to occur, students will need good information about the labour market consequences of their study choices, and the education and training system will need to be responsive to skills demand emanating from the labour market. The need to engage in lifelong learning is also likely to be greater than ever. In many cases workers will need to retrain for new occupations because their old occupations will become obsolete. With the possibility of more workers being displaced than in the past, greater efforts may be needed to help get such workers back into work. Some predominantly low-skilled welfare beneficiary groups, notably disability- and sole parent beneficiaries, face challenging labour market conditions, calling for reinforced activation measures so that their skills can grow instead of atrophying, which would facilitate better integration of these groups into society.

For New Zealanders to get the most out of their skills, it is not just a question of adapting them to labour market requirements and using them, but also of whether or not skills are allocated to their most productive uses. New Zealand stands out as having substantial skills mismatches. Reducing them would increase both wages and productivity. To a large extent, many of these mismatches are attributable to the preponderance of very small firms in New Zealand and a relatively high share of part-time work. Even so, steps could be taken to reduce mismatches. One way of reducing over-qualification is for more young New Zealanders to acquire qualifications in fields with good labour market prospects as this would reduce the proportion of field-mismatched workers, many of whom are obliged to accept work that only requires lower levels of education attainment. To reduce mismatch in information-processing skills (such as literacy, numeracy and problem solving in a technologically rich environment), the most important reforms are those that increase the responsiveness of new housing supply to demand, thereby reducing the cost to workers of relocating to find a better job match.

This paper begins with a discussion of the labour market implications of skill-biased technological change, including labour force upskilling, the future of work and the emergence of non-standard working arrangements. The remainder considers policies to facilitate adaptation to these challenges. Such policies include those aimed at increasing education attainment, reducing qualification and skills mismatches, strengthening information-processing skills, helping displaced workers get back to work and reinforcing activation of those disabled with unused work capacity and of sole parents.

1. The corresponding author is David Carey (david.carey@ oecd.org) from the OECD Economics Department. He would like to thank Willem Adema, David Grubb, Herwig Immervoll, Thomas Liebig and Glenda Quintini (all from the OECD Directorate for Employment, Labour and Social Affairs), Pierre Gouedard (OECD Directorate for Education and Skills), Muge Adalet McGowan, Andrew Barker, Robert Ford, Peter Jarrett, Alvaro Pereira and Volker Ziemann (all from the OECD Economics Department) and NZ government officials for their valuable comments and suggestions. Special thanks go to Isabelle Luong for research assistance and Amelia Godber and Heloise Wickramanayake for editorial support. 


\section{The labour market implications of technical change}

\section{Employment is growing faster for high-skilled workers than for others}

Technical change has long been increasing demand for more highly skilled workers relative to demand for other workers. In the early $20^{\text {th }}$ century the diffusion of electricity boosted productivity in industry and services, increasing demand for workers with complementary skills and reducing it for lowskilled labour, especially in the agricultural sector. The process continued as subsequent waves of technology were diffused, including telephones, the automobile, aeroplanes and, especially since the 1980s, information and communications technology (ICT). Technical change is increasing the demand for more highly skilled workers relative to others because high-skilled workers are complementary to the new technologies, which increases their productivity.

The effects of technical change can be seen in the more rapid growth of employment in occupations with high average levels of education attainment than in others. In New Zealand the share of workers employed in high-skilled occupations, such as professionals and managers, has increased since 1960, while the share in predominantly low-skilled occupations, such as production and related workers and agricultural workers, has declined (Figure 1, Panel A). The employment share for other occupations, which have average education levels between these two groups, rose until the early 1990s but has since fallen, reversing most of the increase since 1950. Similar patterns can be observed in other OECD countries (Handel, 2012), including Australia (Panel B) and the United States (Panel C), albeit less pronounced and later than in New Zealand.

From the early 1980s to the late 1990s, the job shift toward high-skilled occupations and away from low-skilled occupations in New Zealand was particularly rapid, even relative to the United States. The NZ spurt is likely to have been associated with structural reforms that increased product-market competition and made public enterprises more efficient (reducing over manning with low-skilled workers). Low-skilled workers displaced at this time took longer to find new jobs than their high-skilled counterparts, contributing to the sharp shift towards high-skilled workers. A faster increase in educational attainment in New Zealand (and Australia) than in the United States at this time is likely also to have contributed.

Job skill requirements appear to have been increasing slowly in OECD countries, giving time for the labour force to adapt, notably through educational choices. Handel (2012) finds that both for the United States and Europe the shifts in employment shares associated with evolution towards a post-industrial society involve rising demand for both cognitive and interpersonal skills and declining demand for both skilled and unskilled physical abilities. In the United States, for example, mean job education requirements increased by 0.15 years over 1997-2009. Over the same period, mean cognitive, verbal and interpersonal/social skill requirements rose by 0.07-0.11 standard deviations. By contrast, mean craft, physical and repetitive skill requirements declined by 0.02-0.06 standard deviations. At these rates it would take 80 years for job education requirements to rise by one year and for cognitive and skills demands to rise by 0.5-0.75 standard deviations. Within broad occupational groups, there was virtually no change in average skill requirements. Similar results pertain for Europe. While New Zealand was not included in this study, there was little variation in results for the countries that did participate, suggesting that the conclusions may well also be applicable to New Zealand. This is all the more likely, given that occupational skill measures tend to be similar across countries (Handel, 2012) and that shifts in occupation employment shares in New Zealand are similar to those in many other OECD countries.

Since the 1980s, digitalisation has been the dominant form of technical change. It has automated many repetitive tasks, a process referred to as routine-replacing technical change. This has most affected many middle-skilled jobs. By contrast, high-skilled jobs have many abstract tasks, and many low-skilled jobs, such as personal carers, require motor skills, judgement and/or social interaction (Autor et al., 2003). 
Routine-replacing technical change is hypothesised to lie behind the rise in employment shares of highand low-skilled occupations in Europe and the United States in recent decades and falls in the shares of middle-skilled occupations, a phenomenon known as polarisation or "hollowing out" (Autor, 2015; Goos et al., 2014). In New Zealand the employment share rose markedly for high-skilled occupations over 1991-2011, whether classified on the basis of earnings or average years of education, but fell for middleskilled and low-skilled occupations, especially the former (Table 1).

Figure 1. Long-run broad occupational employment shares

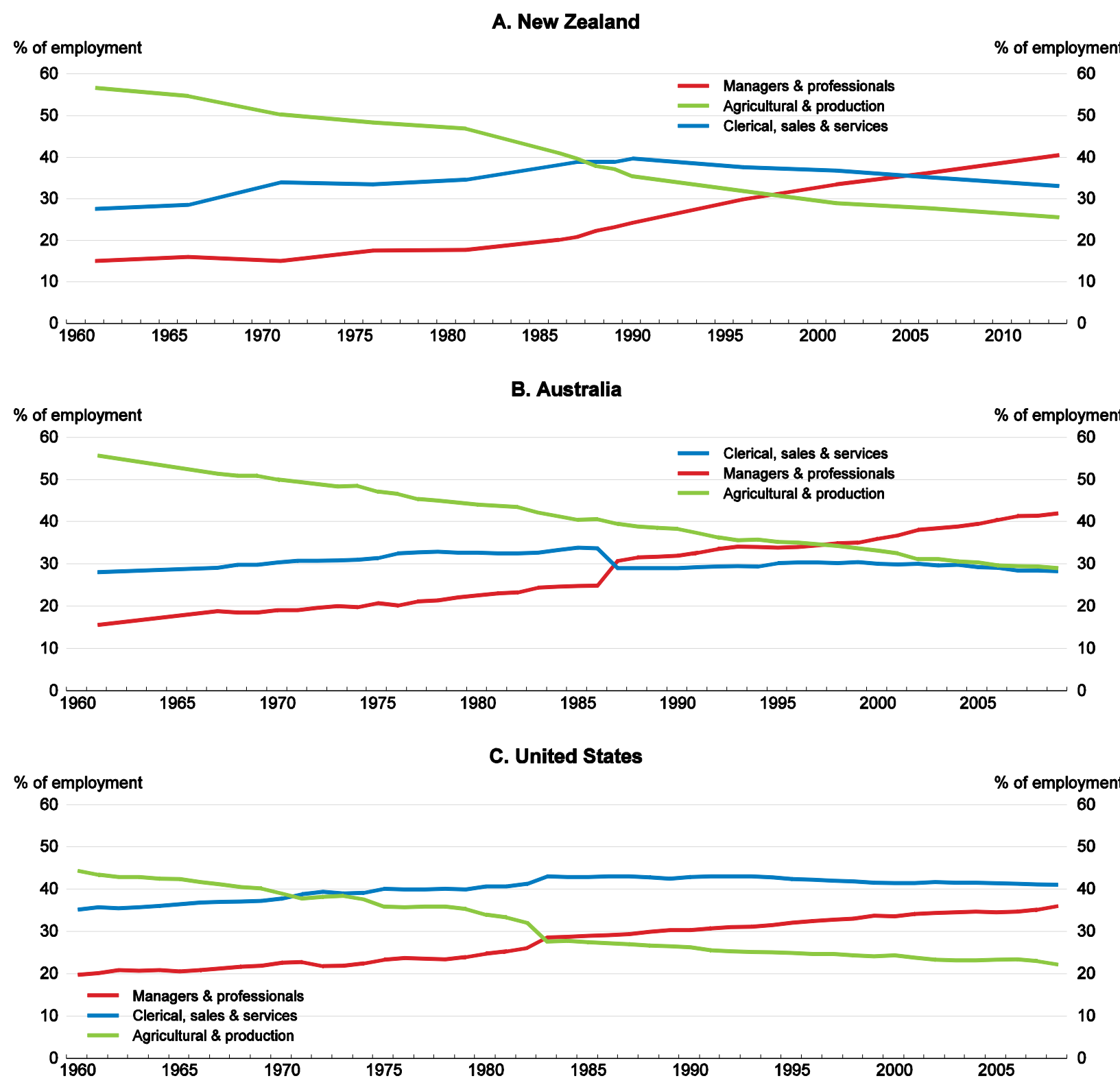

Source: M. Handel (2012), "Trends in Job Skill Demands in OECD Countries", OECD Social, Employment and Migration Working Papers, No. 143; Statistics New Zealand, 2013 Census QuickStats about work and unpaid activities, Table 11. 
Table 1. Levels and changes in occupational employment shares in New Zealand, 1991-2011

\begin{tabular}{lcc}
\hline & $\begin{array}{c}\text { Average employment share } \\
\text { in 1991 }\end{array}$ & $\begin{array}{c}\text { Percentage point change in } \\
\text { employment share, } \\
\text { 1991-2011 }\end{array}$ \\
\hline $\begin{array}{l}\text { Occupations } \\
\text { High paid }\end{array}$ & & \\
Middle paid & 19.5 & 7.3 \\
Low paid & 50.2 & -5.5 \\
& 30.3 & -2.5 \\
\hline High education & & \\
Middle education & 35.4 & 9.5 \\
Low education & 48.6 & -7.1 \\
\hline
\end{tabular}

1. Occupations are defined at the two-digit level of the classification system in use up until 2011. High-paid (low-paid) occupations have median earnings one standard deviation above (below) the all occupation average, while middle-paid occupations have median earnings within one standard deviation of the all occupation average.

\begin{abstract}
High-education occupations typically require tertiary education. They include teaching professional, other professionals, life science professionals, science professionals, life science associate professors, public administration, science associate professors, other associate professors and corporate managers.

Middle-education occupations typically call for upper secondary attainment. They include office clerks, customer service, building trades, metal and machinery trades, precision trades, agriculture and fisheries personal services, sale persons and other trades.

Low education occupations have limited educational requirements. These occupations include industrial plant operators, building and related occupations, machine operators, elementary occupations and drivers.
\end{abstract}

Source: Statistics New Zealand, Household Labour Force Survey.

Bessen (2016) finds that polarisation in the United States occurred in occupations with below-average computer use but not in occupations with above-average computer use (Figure 2). He finds that computerisation increases the productivity of workers who use computers more intensively than others, the more so the more highly skilled they are. Over time occupations that use computers intensively substitute for others in employment. He also finds that there has even been an increase in demand for employees with university degrees in occupations that do not normally require a university degree if they have high rates of computerisation. Rising computer use is associated with growth in well-paid jobs and shrinkage in others. To shift to these well-paid occupations workers need to learn new complementary skills, which are costly or difficult to acquire, so only some workers do so. This leads to greater wage inequality within occupations. Computer use is estimated to have accounted for $38-45 \%$ of the increase in wage inequality in the United States since 1990 (ibid). Bessen also finds that polarisation in the United States may have been caused by other factors, such as globalisation, if repetitive cognitive tasks are easier to offshore than others. New Zealand is well placed to face changes brought about by computer use as PIAAC found its workforce had very high overall skills when testing problem solving in a technologically rich environment, and had a very small proportion of the workforce with below average skills. 
Figure 2. Job polarization: employment growth of occupations by computer use in the United States'
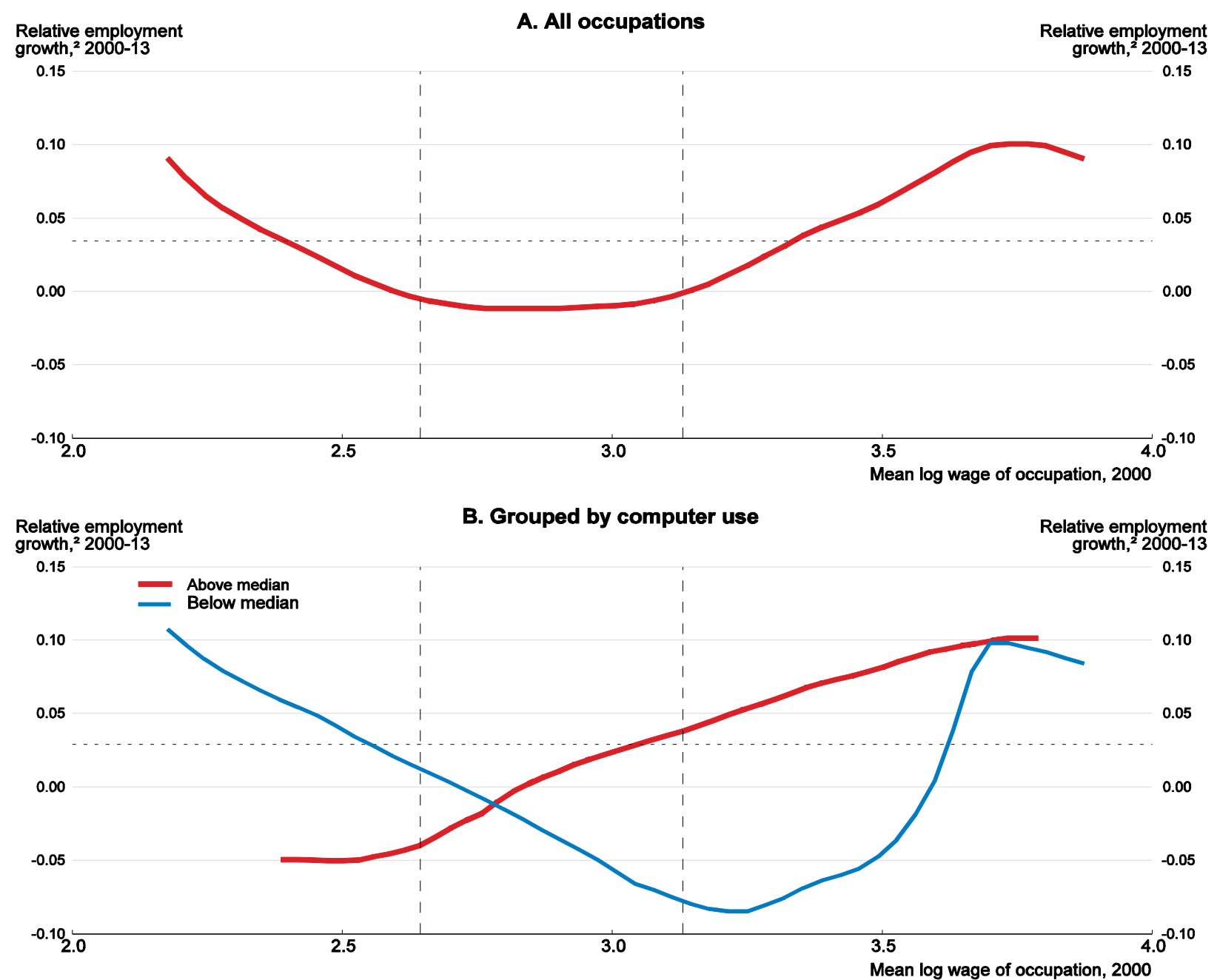

1. Shows smoothed weighted average of percentage growth in hours worked for 317 detailed occupations. Smoothing done with an Epanechnikov kernel with 0.3 bandwidth. Panel B shows occupations with above-median and below-median computer use separately. Dashed vertical lines are at the 25th and 75th percentiles in the occupational wage. Horizontal dotted line is total hours growth.

2. Annual growth in employment relative to the entire labour force.

Source: J. Bessen (2016), "How Computer Automation Affects Occupations: Technology, Jobs and Skills", Boston University School of Law - Law \& Economics Working Paper, No. 15-49, October, http://www.bu.edu/law/faculty/scholarship/working-paper-series.

\section{The supply of high-skilled workers is growing faster than the supply of others}

The supply of skills, as measured by educational attainment, has been steadily increasing in New Zealand. The proportion of the population with less than upper secondary attainment is lower for 2534 year-olds than for 55-64 year-olds, while a much higher proportion of 25-34 year-olds have tertiary education than do 55-64 year-olds; there has also been a small increase in upper secondary or equivalent attainment (Figure 3). However, increases in educational attainment have been greater in most other countries, and levels are also higher for the younger age group than in New Zealand. A greater proportion of 25-34 year-olds have less than upper secondary attainment in New Zealand than the OECD average (Figure 4, Panel A), and a smaller proportion have tertiary attainment (Panel C). Young people from lower socio-economic and/or Māori/Pasifika backgrounds are over-represented among those who have less than 
upper secondary attainment and under-represented among those who have tertiary attainment (Ministry of Education, 2015). In contrast to most other countries, the higher share of the 25-34 age group with tertiary attainment than the 55-64 age-group share uniquely reflects the increase in attainment at the Bachelor's degree level, with no increase at the post-graduate level (Figure 5). The proportion of the 25-34 age group with post-graduate attainment is much lower than in most other OECD countries. This may reflect the preponderance of small firms in New Zealand, as they offer fewer highly specialised jobs than large firms. The share of 25-34 year-olds with short-cycle tertiary attainment is also lower than in most other OECD countries.

Figure 3. Educational attainment gap between young and old, 12015

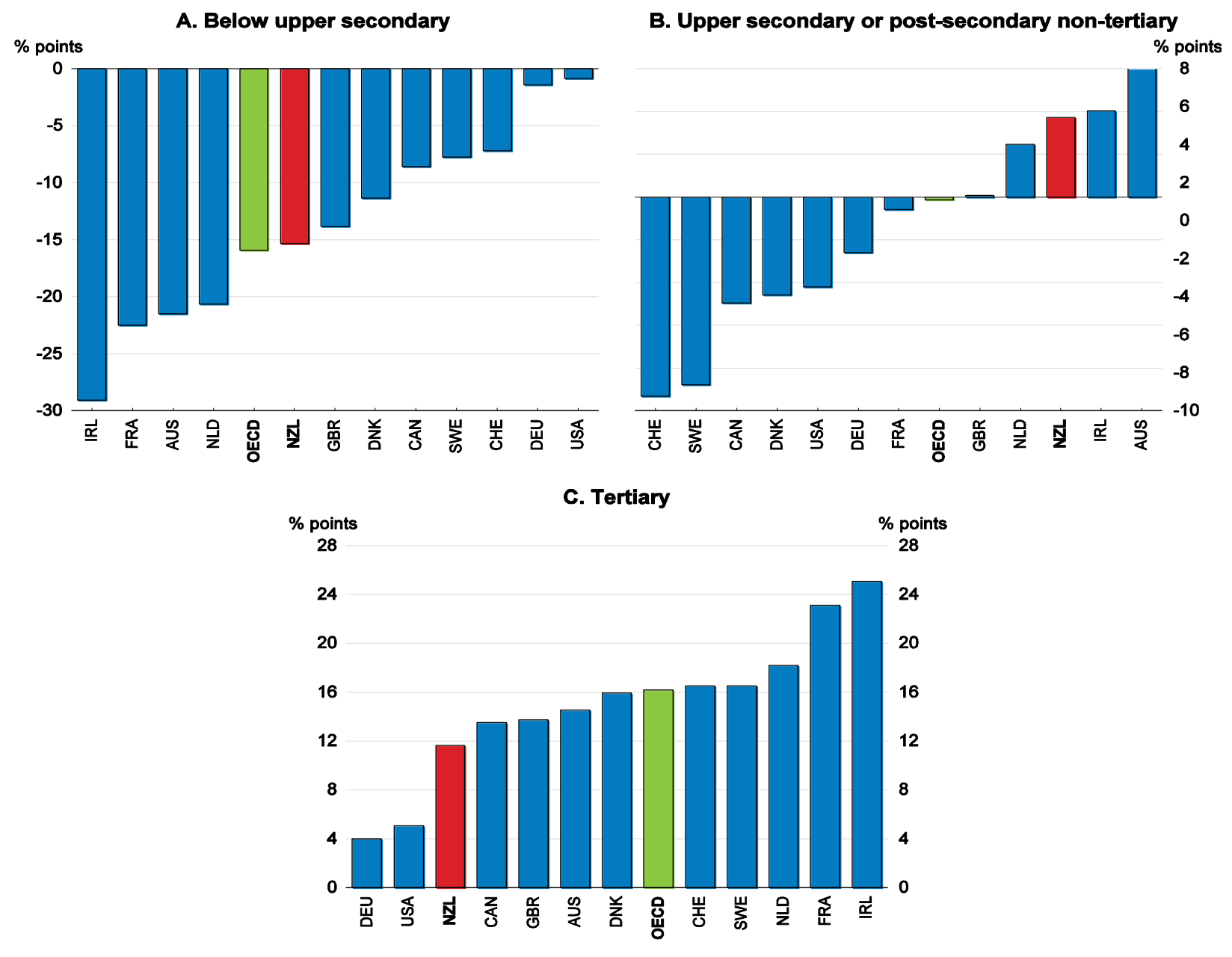

1. The young are defined as the 25-34 year-olds age group and the old as the 55-64 year-olds age group.

Source: OECD (2016), Education at a Glance 2016: OECD Indicators, Table A1.3. 
Figure 4. Level of educational attainment of the young, ${ }^{1} 2015$

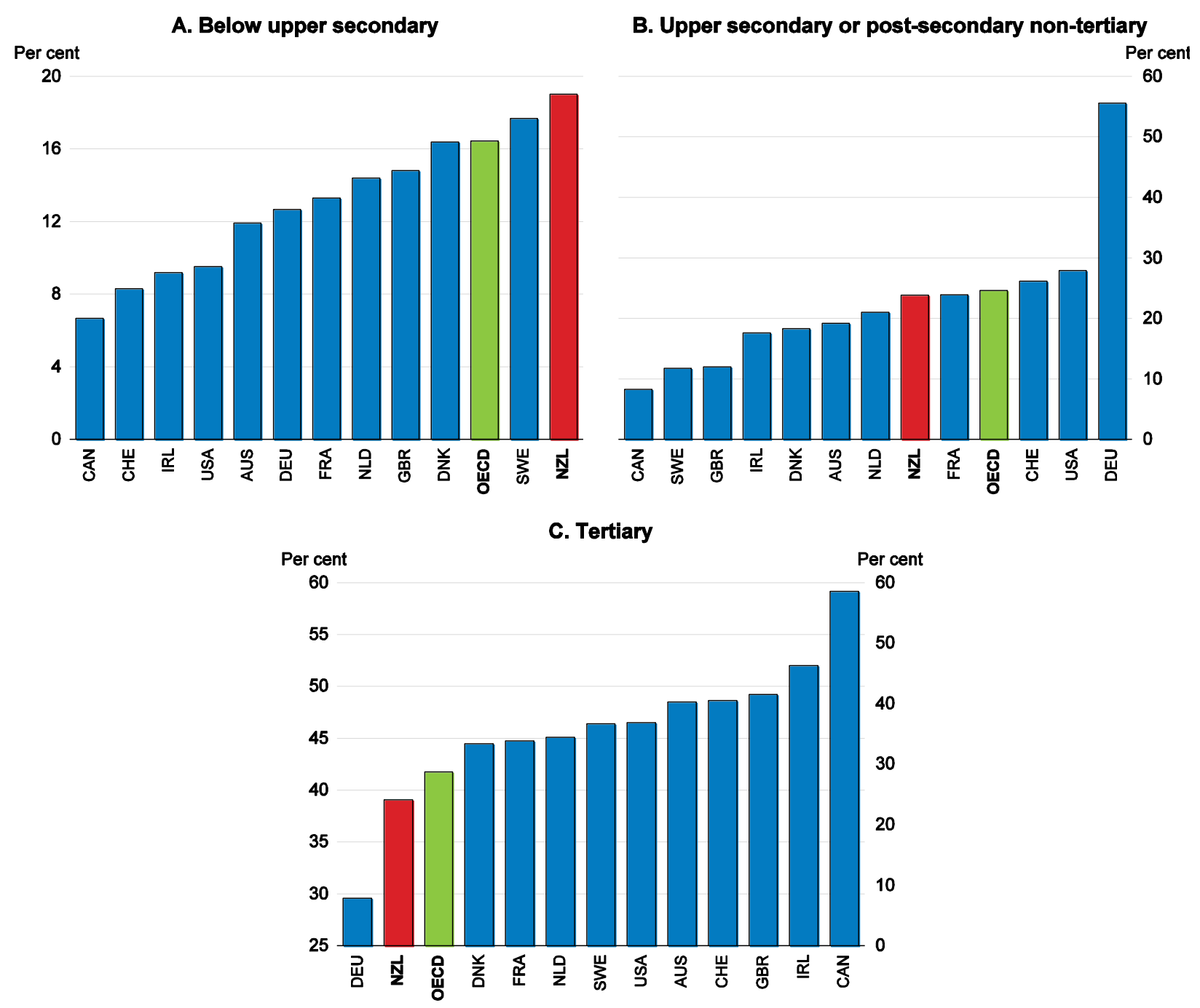

1. The young are defined as the 25-34 year-olds.

Source: OECD (2016), Education at a Glance 2016: OECD Indicators, Table A1.3. 
Figure 5. Decomposition of tertiary education attainment by age group, 2015

\section{A. 25-34 year-olds}

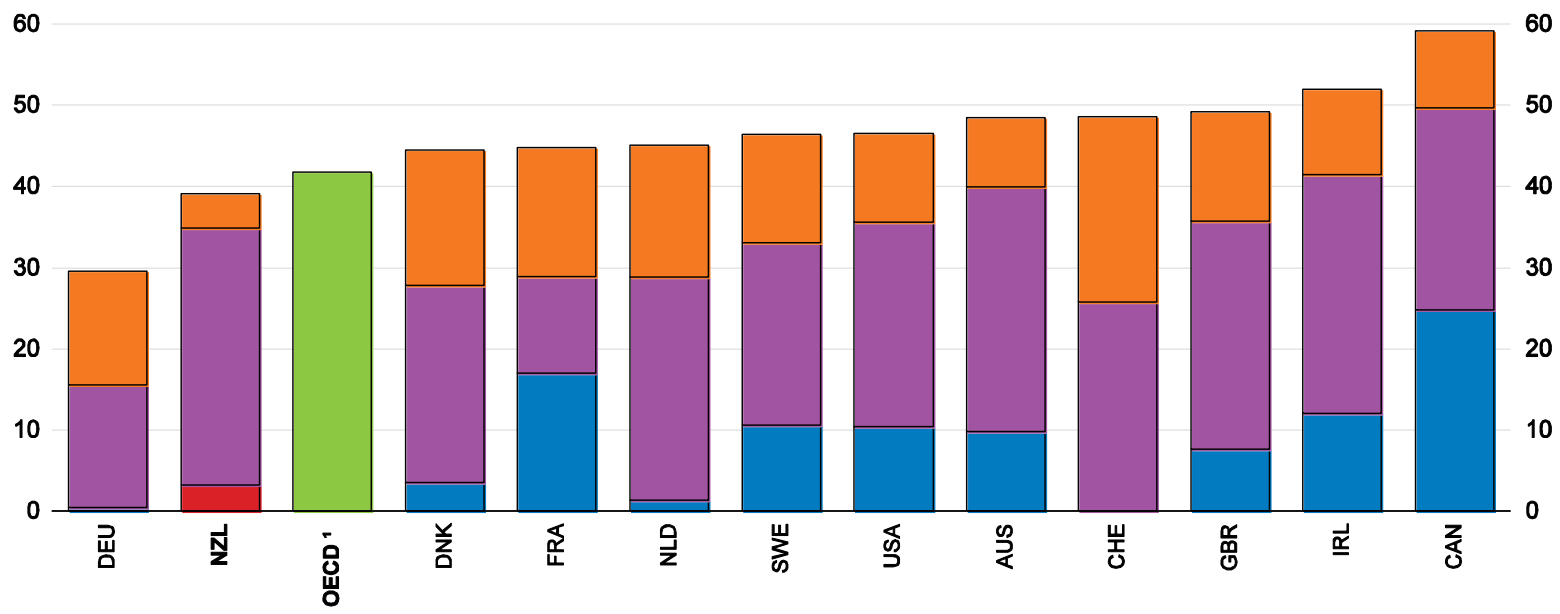

\section{B. 55-64 year-olds}

60

40

30

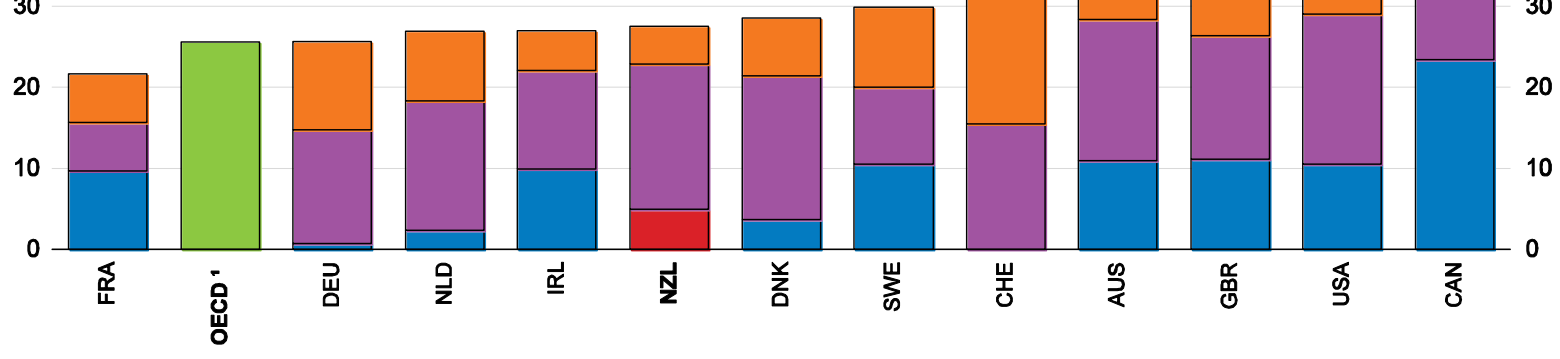

1. As there are missing data for some sub-components for some countries, only the total tertiary for the OECD average is shown.

Source: OECD (2016), Education at a Glance 2016: OECD Indicators, Table A1.2.

International migration is contributing to the rising supply of skills in New Zealand. Over time, New Zealand has gained more people with university degrees through immigration than it has lost through emigration. As a share of New Zealand's population aged 15 or over in 2010, immigrants comprised 55.3\% of those with high (i.e., tertiary) education while NZ citizens with high education living abroad (i.e., emigrants) represented $29.1 \%$ (Table 2). Thus, net migration contributed $26.3 \%$ of the NZ population aged 15 or over with high education. By contrast, net migration only contributed $8.8 \%$ of the population with less than university attainment. In subsequent years, for which data are available only by occupation, international migration has continued to add to the stock of highly skilled workers. Net immigration of professionals, who have the highest average level of education attainment, was far higher than for any other occupational group over 2011-16, although some professionals may not be very highly skilled judging by their earnings. At the other end of the spectrum, there were population losses from net migration in low-skilled occupations. These outcomes suggest that New Zealand's immigration policy has continued to contribute to upskilling of the NZ population, more than offsetting the effects of large outflows of high-skilled workers. In April 2017 the government announced a series of changes, including 
adding remuneration thresholds for the Skilled Migrant Category (residence), which should result in higher-skilled immigrants. While data on permanent and long-term migration continue to show a preponderance of net immigration in generally higher-skilled occupations, it should be borne in mind that these data do not capture short-term (i.e., less than one year) migration flows, such as for the Working Holiday Schemes and Study to Work, which have grown substantially and generally entail low-skilled work, and that migrants may undertake less skilled work in New Zealand than in their home country.

Table 2. Impact of net migration on the skills of the population

\begin{tabular}{|c|c|c|c|}
\hline & Immigration & Emigration & Net migration \\
\hline Education level $^{1}$ & \multicolumn{3}{|c|}{ Stocks (thousands), 2010} \\
\hline High education & 332.6 & 174.7 & 157.9 \\
\hline Low-middle education & 551.6 & 340.5 & 211.1 \\
\hline \multirow[t]{2}{*}{ Total } & 884.2 & 515.2 & 369.0 \\
\hline & \multicolumn{3}{|c|}{$\%$ of population aged 15 and over, 2010} \\
\hline High education & 55.3 & 29.1 & 26.3 \\
\hline Low-middle education & 23.0 & 14.2 & 8.8 \\
\hline Total & 29.5 & 17.2 & 12.3 \\
\hline Occupation $^{2}$ & \multicolumn{3}{|c|}{$\%$ share, $2011-16$} \\
\hline Professionals & 37.4 & 33.9 & 52.2 \\
\hline Managers & 9.8 & 10.1 & 8.9 \\
\hline Clerical and administrative workers & 6.9 & 7.2 & 5.6 \\
\hline Technicians and trade workers & 17.4 & 16.2 & 23.1 \\
\hline Community and personal service workers & 13.7 & 14.0 & 12.4 \\
\hline Sales workers & 6.1 & 7.9 & -1.6 \\
\hline Labourers & 5.6 & 6.5 & 1.8 \\
\hline Machinery operators and drivers & 3.0 & 4.1 & -1.8 \\
\hline Total of above occupations (thousands) & 243.1 & 196.3 & 38.6 \\
\hline
\end{tabular}

1. Low education refers to lower secondary education; medium education corresponds to upper secondary education and postsecondary non-tertiary education; and high education refers to tertiary education.

2. Occupations of permanent and long-term migrants ranked by decreasing years of education.

Source: Statistics New Zealand; OECD (2015), Connecting with Emigrants - A Global Profile of Diasporas 2015.

\section{Growth in supply of skills appears to have been well calibrated with non-cyclical growth in demand}

It is difficult to judge whether growth in the supply of skills has been well calibrated to growth in demand for skills in New Zealand over the long term owing to a lack of data on earnings by level of education attainment. Over the period 2005-16, for which data are available, earnings premiums point to relative demand for workers with short-cycle tertiary qualifications or post-secondary non-tertiary qualifications running ahead of supply (Table 3). The timing of these gains suggests that the Canterbury rebuild and expansion in construction activity in Auckland were important factors. The decline in the share of the population with such qualifications also contributed to the shortage (Table 4). Earnings premiums for higher tertiary qualifications display no clear trend, suggesting that relative demand broadly increased in line with relative supply. Short-cycle tertiary earnings premiums are higher than in Australia and the United States while premiums for people with bachelor's or higher qualifications are higher than in Australia but much lower than in the United States (OECD, 2016a). 
Table 3. Earnings premiums for NZ workers ${ }^{1}$ by level of educational attainment

\begin{tabular}{|c|c|c|c|c|c|c|c|c|}
\hline \multicolumn{9}{|c|}{ Upper secondary education $=100$} \\
\hline & 2005 & 2010 & 2011 & 2012 & 2013 & 2014 & 2015 & 2016 \\
\hline Below upper secondary education & 82 & 83 & 82 & 82 & 92 & 94 & 93 & 91 \\
\hline Post-secondary non-tertiary education & 102 & 107 & 107 & 99 & 113 & 113 & 118 & 115 \\
\hline Tertiary education & 124 & 129 & 122 & 121 & 136 & 146 & 145 & 140 \\
\hline Short-cycle tertiary education & 105 & 104 & 101 & 102 & 114 & 127 & 128 & 124 \\
\hline Bachelor's or equivalent education & 141 & 143 & 134 & 132 & 133 & 145 & 139 & 133 \\
\hline Master's, Doctoral or equivalent education & .. & .. &.. &.. & 174 & 176 & 177 & 166 \\
\hline
\end{tabular}

1. Earnings of full-time, full-year workers aged 25-64.

Source: OECD (2016), "Education and earnings", Education at a Glance (database).

Table 4. Education attainment by highest level of qualification

Population aged 15 years and over, per cent of all qualifications

\begin{tabular}{lccccccc}
\hline & 2005 & 2010 & 2011 & 2012 & 2013 & 2014 & 2015 \\
\cline { 2 - 7 } No qualifications or not stated & 26.3 & 25.6 & 24.5 & 24.2 & 24.4 & 22.7 & 22.2 \\
School qualification & 25.0 & 23.6 & 24.5 & 23.9 & 25.8 & 26.0 & 25.7 \\
Tertiary diplomas/certificates & 34.2 & 33.1 & 33.6 & 33.7 & 29.8 & 29.7 & 30.7 \\
Bachelors degree or higher & 14.5 & 17.7 & 17.4 & 18.3 & 20.0 & 21.5 & 21.4 \\
\hline
\end{tabular}

Source: Ministry of Education, Education Counts.

Trends in unemployment and inactivity rates may be indicative of growing short-term skills shortages. For the population aged 25-64, unemployment rates only rose modestly $(22 \%)$ for people with tertiary education attainment (as a proxy of skills) between 2005 and 2015 but doubled for others (Table 5). These differences were more pronounced for the population aged 25-34, for whom rates more than doubled for those with up to secondary attainment and were unchanged at the tertiary level. Inactivity rates (defined as $100 \%$ minus the participation rate), fell markedly (by around 30\%) between 2005 and 2015 for people with tertiary attainment, but not for others.

Table 5. Employment, unemployment and inactivity rates by educational attainment and age group

\begin{tabular}{|c|c|c|c|c|c|c|}
\hline & \multicolumn{2}{|c|}{$\begin{array}{c}\text { Below upper } \\
\text { secondary education }\end{array}$} & \multicolumn{2}{|c|}{$\begin{array}{l}\text { Upper secondary } \\
\text { and post-secondary } \\
\text { non-tertiary } \\
\text { education }\end{array}$} & \multicolumn{2}{|c|}{ Tertiary education } \\
\hline & 2005 & 2015 & 2005 & 2015 & 2005 & 2015 \\
\hline \multicolumn{7}{|c|}{ Employment rate } \\
\hline $25-34$ year-olds & 67.9 & 63.3 & 81.7 & 78.4 & 81.5 & 86.1 \\
\hline 25-64 year-olds & 70.0 & 69.1 & 84.2 & 81.3 & 84.1 & 87.5 \\
\hline \multicolumn{7}{|c|}{ Unemployment rate } \\
\hline 25-34 year-olds & 5.5 & 11.2 & 3.0 & 6.8 & 3.3 & 3.3 \\
\hline 25-64 year-olds & 3.4 & 6.2 & 2.3 & 4.8 & 2.3 & 2.8 \\
\hline \multicolumn{7}{|l|}{ Inactivity rate $^{1}$} \\
\hline 25-34 year-olds & 26.6 & 25.5 & 15.3 & 14.8 & 15.2 & 10.6 \\
\hline 25-64 year-olds & 26.6 & 24.7 & 13.5 & 13.9 & 13.6 & 9.7 \\
\hline
\end{tabular}

1. The inactivity rate is calculated by dividing working-age population not in the labour force by the working-age population.

Source: OECD (2016), "Educational attainment and labour force status", Education at a Glance (database). 
The Manpower Group survey of employers also indicates that there are short-term skills shortages, which are greater than in most other countries (Figure 6, Panel A). These shortages increased markedly following the Canterbury earthquakes but have been declining since 2014, albeit to higher levels than a decade ago (Panel B). NZ firms report that the hardest jobs to fill are for skilled tradespersons, engineers, sales representatives and management/executives (Panel C). Demand for workers in the first two categories has been boosted by the large increase in construction activity associated with the Canterbury earthquake rebuild and, more recently, housing and infrastructure investment, especially in Auckland. Wage increases in the construction industry have outpaced those in other industries in recent years except real estate, which is also benefiting from some of the same factors. Some construction occupations and engineers are listed as occupations for which there are both long-term and short-term shortages in New Zealand for the purposes of issuing work visas. Firms report that the two top reasons why they find it hard to fill jobs is the lack of available applicants (26\%) and lack of hard skills (technical competences, 24\%) (Manpower Group, 2016). Only $7 \%$ of firms cite the lack of soft skills (workplace competencies) as a reason for difficulties filling vacant positions. However, a number of other surveys and reports have highlighted the need for noncognitive skills (Auckland Co-Design Lab, 2016). Given the short-term nature of this increase in labour demand associated with the Canterbury rebuild, it is appropriate that it has largely been met through temporary immigration instead of through the education and training system.

Figure 6. Firms facing skills shortages 1

As a percentage of all firms with ten or more employees

A. Skills shortages across countries, 2016

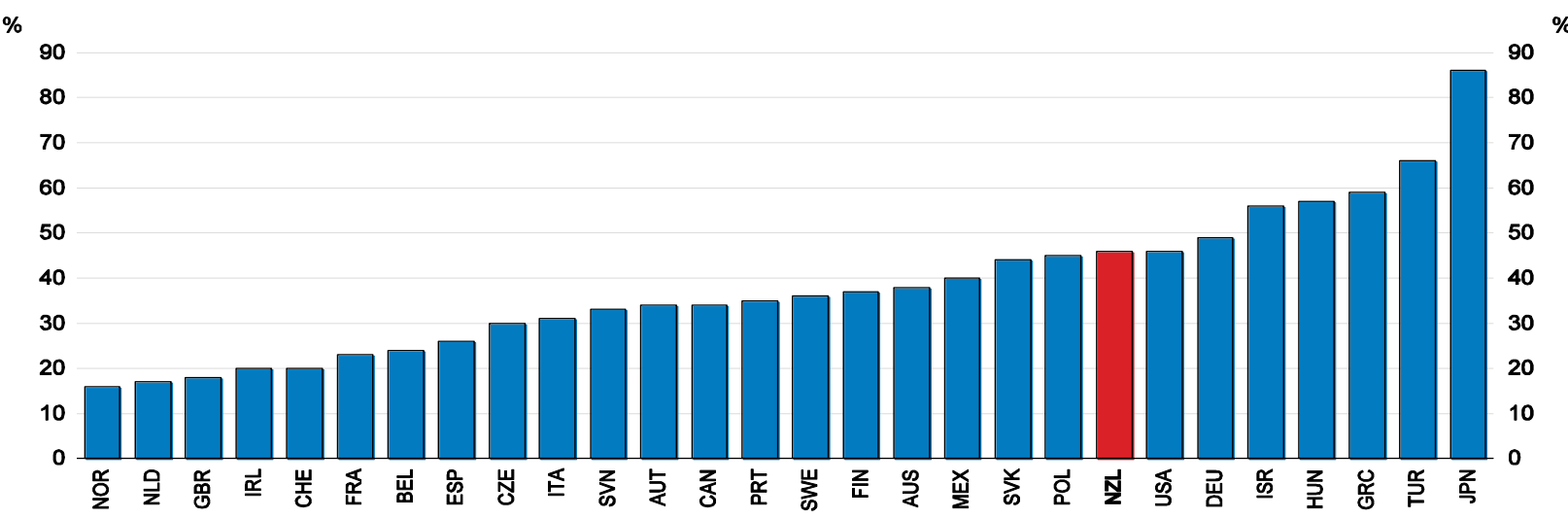

B. SkIlls shortages In New Zealand

$\%$

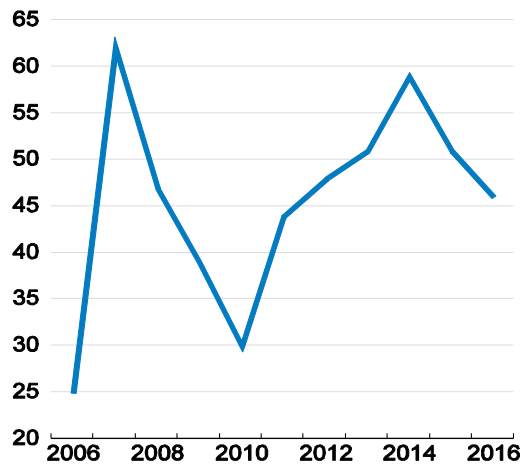

C. Hardest skills to find In New Zealand Jobs ranked by decreasing order of difficulties to find, 2016

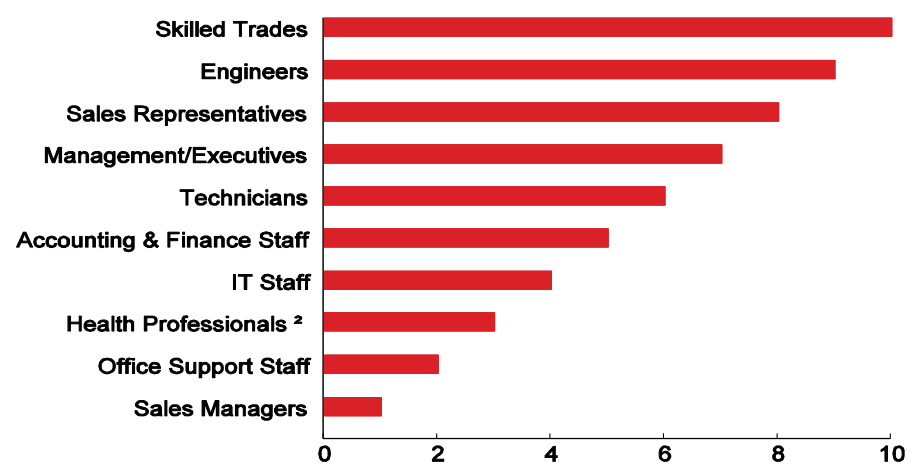

1. Survey based. Firms are classified as facing a skills shortage if they report having difficulties filling jobs.

2. Doctors and other non-nursing.

Source: ManpowerGroup, Talent Shortage Survey, various years. 


\section{The diffusion of digital technologies is expected to favour high-skilled workers}

In a widely quoted study, Frey and Osborne (2013) estimated the risk that narrowly defined occupations in the United States could be automated out of existence in the next couple of decades. They note that many repetitive tasks have already been automated, contributing to weak employment and wage growth for mid-level skills, and that this process will soon have run its course. On the other hand, progress in Artificial Intelligence (AI), which entails machines learning from processing vast amounts of data, will make it possible to automate less routine tasks, such as driving. Frey and Osborne identify the main engineering bottlenecks that will ultimately set the boundaries for the application of computer-controlled equipment to perform tasks currently undertaken by human beings as being: creative intelligence; social intelligence; and perception and manipulation. These bottlenecks make it difficult to automate jobs mainly occupied by people with university degrees but less so to automate low-skilled jobs. Based on expert opinion on tasks that could be automated with likely advances in AI, the authors estimate that $47 \%$ of current employment is in occupations at high risk (more than 70\%) of automation (possibly) over the next decade or two, $19 \%$ in occupations with medium risk (30-70\%) and 33\% in occupations with low risk (less than 30\%). Applying this approach to UK data, Deloitte (2015) show that occupations with a high susceptibility to automation saw sharp employment declines between 2010 and 2015, while jobs that are less exposed experienced rapid growth.

NZIER (2015) applies Frey and Osborne's estimates of job automation to NZ employment data. It finds that $46 \%$ of the NZ labour force faces a high risk of having their current job automated, similar to Frey and Osborne's estimate for the United States; concomitantly, New Zealand's occupational structure is similar to the United States'. As in the United States, the risk of automation is higher for low-skilled jobs than for high-skilled jobs. NZIER finds that $75 \%$ of labouring jobs have a high risk of being automated over the next decade or two, while at the other end of the skills spectrum only $12 \%$ of professional jobs are at high risk of automation (Figure 7). As rural areas of New Zealand have a higher proportion of lowskilled jobs than major urban centres, workers in such areas are more exposed to the risk of job automation.

Figure 7. Employment at high risk of automation

Numbers in brackets represent the number of jobs at high risk, 2015

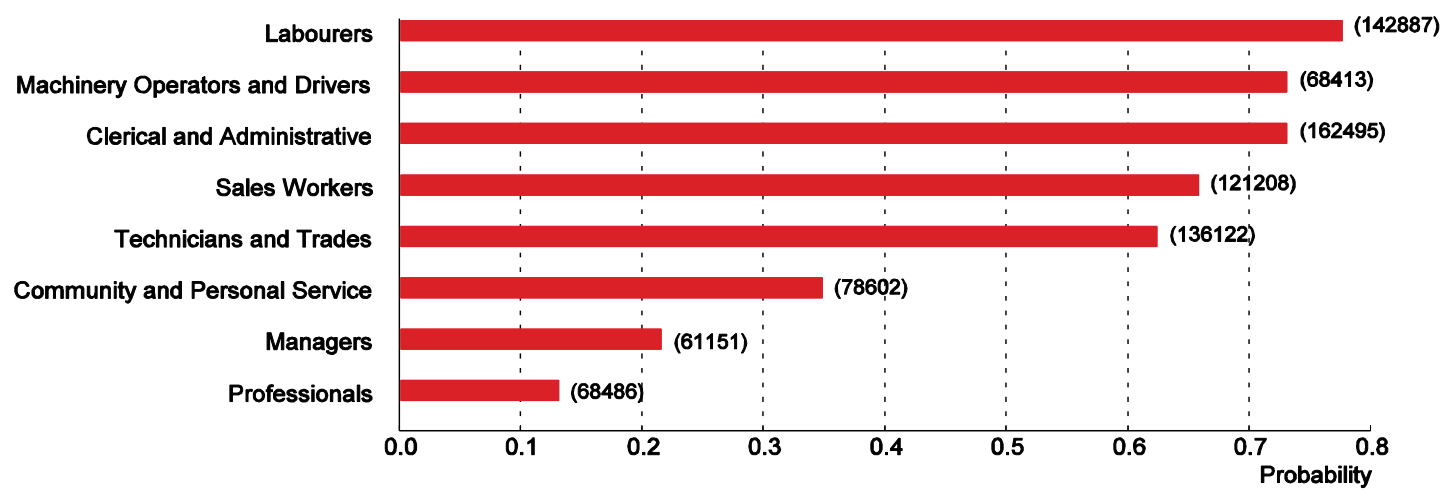

Source: NZIER (New Zealand Institute of Economic Research) (2015), "Robot Nation? The Impact of Disruptive Technologies on Kiwis", NZIER Insight, 55-2015.

However, the Frey and Osborne "occupation-based" approach probably overstates the risks of job losses from automation, as occupations classified as being at high risk often contain many tasks that are hard to automate. Taking a "task-based" approach using the PIAAC data on tasks that workers report using, Arntz et al. (2016) estimate that $34 \%$ of US jobs are at risk (meaning that more than $50 \%$ of tasks could be automated) over the next 10-20 years, with $9 \%$ at high risk (more than $70 \%$ of tasks are automatable) (Figure 8). Results for New Zealand are similar: 35\% of jobs are at risk of automation, with 
9\% at high risk. As in other countries, low-skilled and low-income NZ workers are much more likely to have their jobs automated than high-skilled, high-income workers (Figure 9). Thus, like Frey and Osborne, Arntz et al. find that low-skilled workers are likely to bear the brunt of adjustment costs because the potential to automate their jobs is higher than for highly qualified workers.

Figure 8. Risk of job automation

Jobs at risk of automation, ${ }^{1} 2012$ and $2015^{2}$

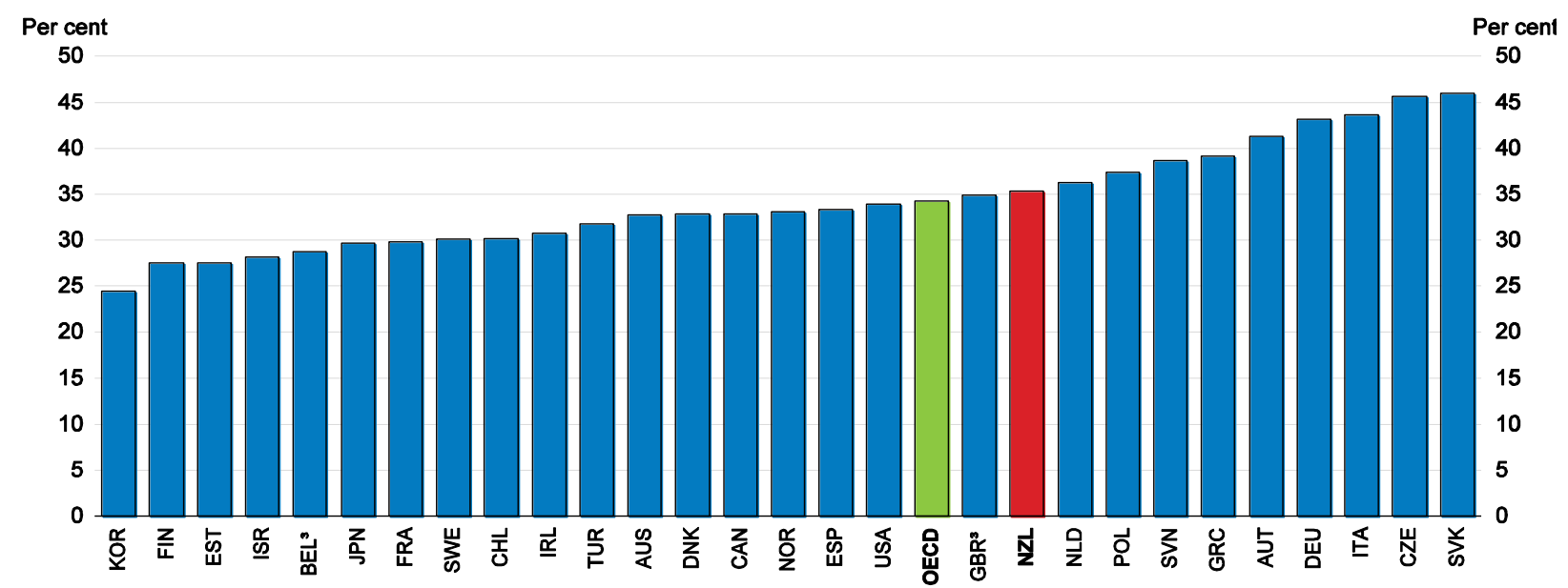

1. Jobs are at risk of being automated if at least (50\%) of their tasks are automatable.

2. Data correspond to $\mathbf{2 0 1 2}$ for countries participating in the first round of the Survey of Adult Skills: Australia, Austria, Belgium, Canada, Czech Republic, Denmark, Estonia, Finland, France, Germany, Ireland, Italy, Japan, Korea, Netherlands, Norway, Poland, Slovak Republic, Spain, Sweden, United States and United Kingdom. Data correspond to 2015 for countries participating in the second round of the Survey of Adult Skills: Chile, Greece, Israel, New Zealand, Slovenia and Turkey.

3. Data for Belgium correspond to Flanders and data for the United Kingdom to England and Northern Ireland.

Source: OECD calculations based on the Survey of Adult Skills (PIAAC) (2012, 2015); M. Arntz et al. (2016), "The Risk of Automation for Jobs in OECD Countries: A Comparative Analysis", OECD Social, Employment and Migration Working Papers, No. 189, http://dx.doi.org/10.1787/5jlz9h56dvq7-en.

Figure 9. Share of NZ workers with high automation potential by education attainment and income level Share of workers in jobs at high risk of automation, ${ }^{1} 2015$

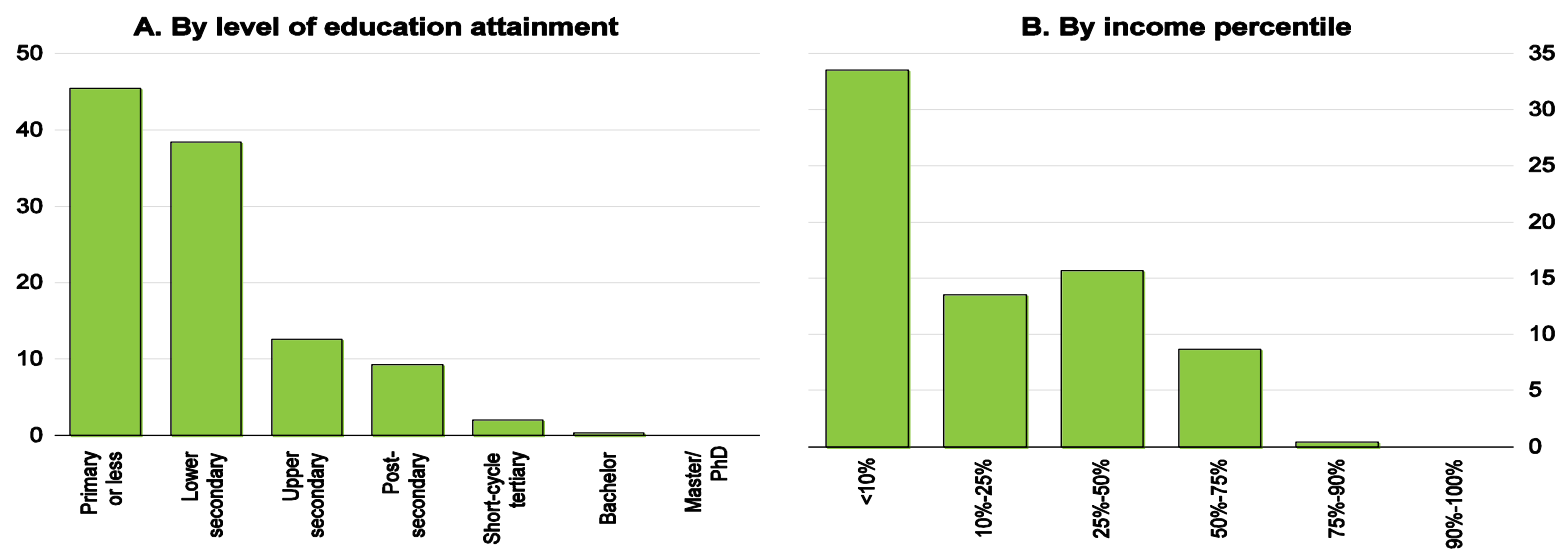

1. Workers are at high risk of automation if at least $70 \%$ of their tasks are automatable.

Source: OECD calculations based on the Survey of Adult Skills (PIAAC) (2015); M. Arntz et al. (2016), "The Risk of Automation for Jobs in OECD Countries: A Comparative Analysis", OECD Social, Employment and Migration Working Papers, No. 189, http://dx.doi.org/10.1787/5jlz9h56dvq7-en. 
As discussed above, working in an occupation at medium to high risk of automation does not necessarily lead to job loss. Indeed, the increase in productivity from computerisation can expand demand for employees in an occupation as they are substituted for employees in other occupations benefiting less from computerisation (Bessen, 2016). At the same time, however, the tasks performed will evolve from routine towards non-routine tasks that require higher levels of judgement and social interaction. Many occupations, including currently low-skilled ones, will become more highly skilled. As discussed above, increased demand will be strongest in high-skilled occupations with heavy computer use. Thus, allowing for substitution effects does not alter the conclusion that the low-skilled are likely to be the hardest hit by the diffusion of digital technologies, potentially increasing inequalities in income.

\section{Many workers with disabilities will face more difficult labour market conditions}

A disproportionate share of low-skilled workers world-wide has health problems or disabilities. Workers with these problems are far more likely than others not to have completed upper secondary education, more likely to have dropped out of school prematurely and less likely to have benefitted from job-related vocational training (OECD, 2010). The education gap between people with and without disabilities is larger for younger cohorts than for older ones in most OECD countries, exposing younger cohorts of workers with disabilities more to the negative effects of skill-biased technological change on employment opportunities. Access to jobs by disabled individuals has become more difficult in recent years owing to changing working conditions in OECD countries in response to greater competition and more rapid technical change. Job security has declined for a growing number of workers on temporary or atypical contracts, and workloads and work pressure have increased (OECD, 2010). Social integration of people with disabilities is poor, with lower employment rates and higher inactivity, unemployment and poverty rates than for people without disabilities.

The share of the working-age population receiving a disability benefit doubled in New Zealand between 1990 and 2007, when it reached around 4\%, but has since been stable (Figure 10, Panel A). This rate is lower than in most other OECD countries (OECD Social Expenditure Database). Benefit receipt rates also increased in other English-speaking countries (with data), where rates remain higher than in New Zealand. As in most other countries, the rising structural trend in disability benefit receipt rates is not entirely attributable to population ageing (older working-age cohorts have much higher disability rates than younger groups) (OECD, 2010). Public expenditure on disability is around $2 \frac{1}{2}$ per cent of GDP in New Zealand, which is close to the OECD average (Panel B). This comparatively higher expenditure in relation to the benefit receipt rate reflects the fact that New Zealand does not have partial disability benefits, which compensate for loss of earnings from partial disability and consequently are smaller than benefits for full disability, in contrast to many other countries. 
Figure 10. Disability benefits

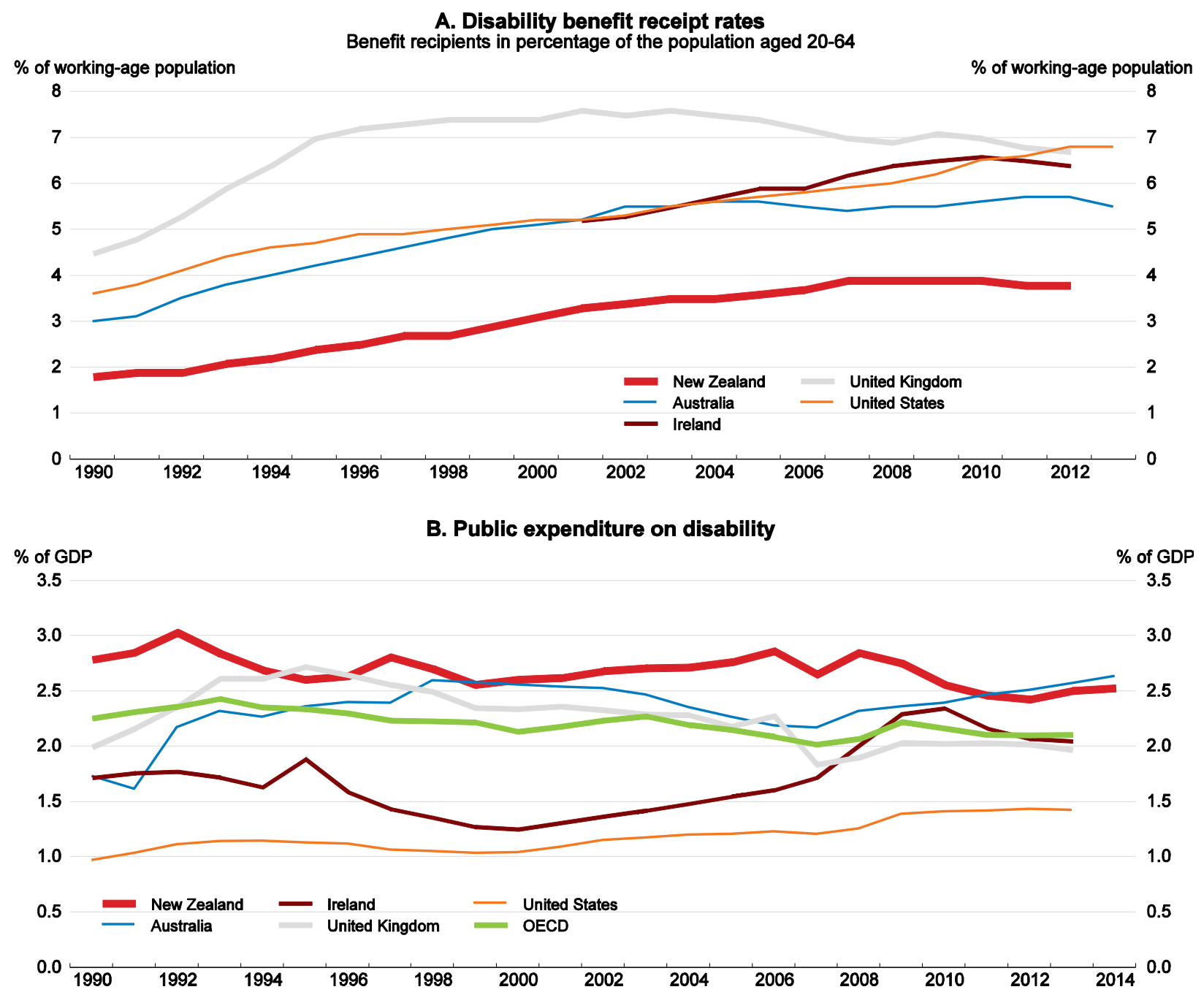

Source: OECD (2010), Sickness, Disability and Work - Breaking the Barriers, Figure 2.9 with updates; OECD (2017), Social expenditure database.

\section{Sole parents will also face more difficult labour market conditions}

A disproportionate share of sole parents also has low educational attainment and as such is likely to encounter increasingly difficult labour market conditions. While recent welfare reforms in New Zealand (see the previous Survey (OECD, 2015a) for more information) have succeeded in increasing the employment rate for sole mothers closer to that for partnered mothers, the gap remains large by international comparison (Figure 11). Under the NZ government's investment approach to welfare payments, scarce activation resources have been targeted on sole parent beneficiaries at greatest risk of long-term benefit dependency. For sole parents these reforms increased the probability of exiting benefit receipt and ended the upward trend in average benefit levels owing to higher rates of part-time work. 
Figure 11. Employment rates of lone parents vs partnered mothers

Parent mothers aged 15-64 years with at least one child aged under 15, 2014 data

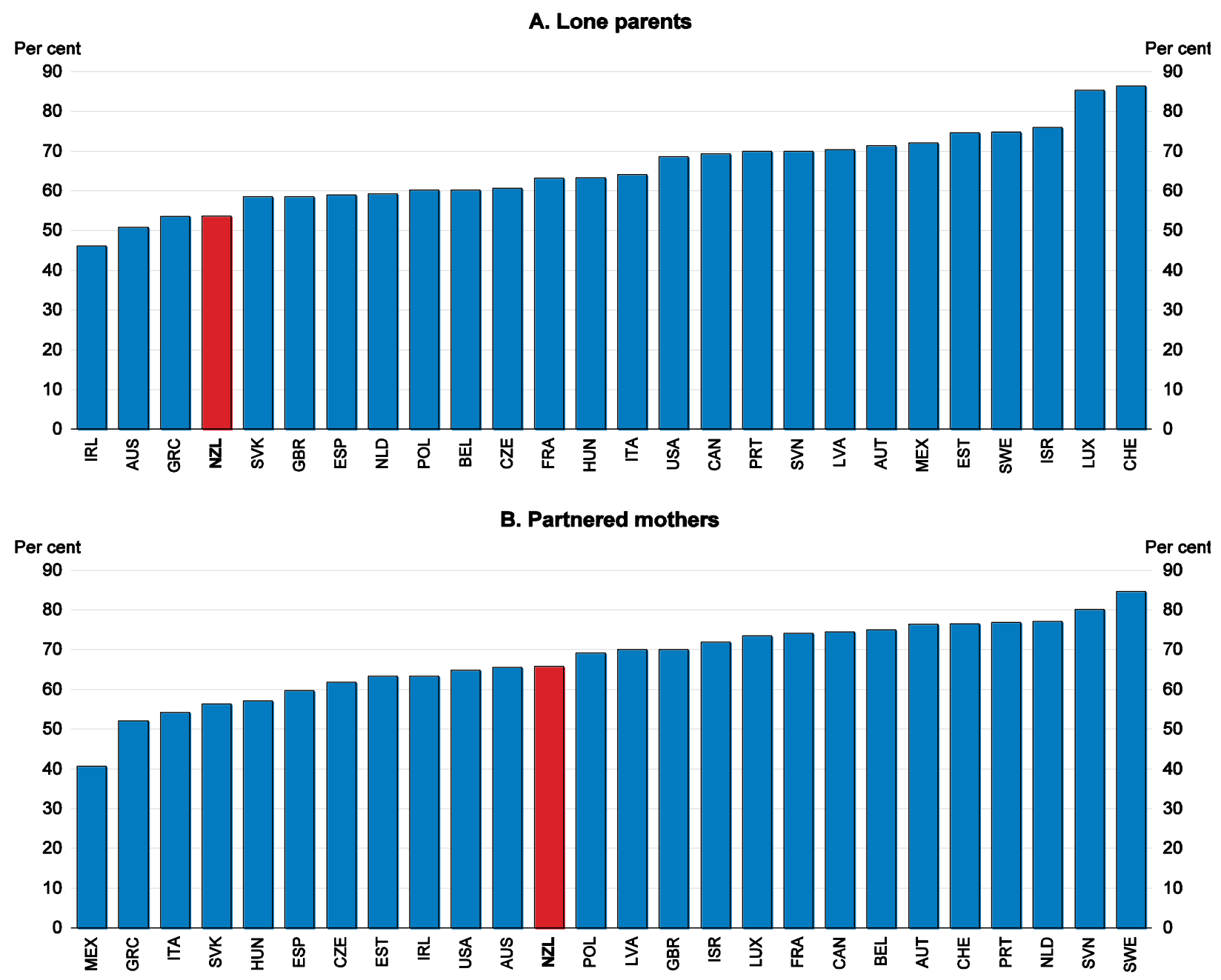

Source: OECD (2016), Family database.

\section{Digital technologies are facilitating the emergence of non-standard work arrangements}

Digital technologies are redefining the boundaries of firms, which, as Coase (1937) explained, are determined by the need to minimise transactions costs within employer-employee relationships. Technical changes that lead to enhanced monitoring, standardised job tasks and that make information on worker reputation more widely available may be reducing the transactions costs associated with contracting out job tasks, thus supporting outsourcing of work (Katz and Krueger, 2016). Katz and Krueger also point out that improvements in information technology and deeper markets for contractors increasingly mean that large organisations may reap efficiency gains and cost savings from hiring specialised contractors for noncore activities (such as janitorial services, food services, information technology, accounting and legal services), rather than managing such activities in-house. Working arrangements beyond the firm boundary are typically described as alternative or non-standard.

The number of people in alternative working arrangements worldwide is growing quickly, although there are no data available to determine whether or not this is also so for New Zealand. Katz and Krueger update the US Bureau of Labor Statistics Contingent Work Survey (CWS) of main jobs to assess recent US 
trends in alternative work, which is defined in the CWS as: agency temporary help workers; on-call workers and contract company workers; and independent contractors or freelancers. They find that the share of workers in alternative working arrangements rose from $10.7 \%$ in February 2005 to $15.8 \%$ in late 2015. This growth in alternative work accounted for $94 \%$ of net employment growth in the United States between 2005 and 2015. They also find that only $0.5 \%$ of workers work through an online intermediary, such as Uber or Task Rabbit. However, the number of people working through such online platforms (sometimes referred to as the 'gig economy') is growing quickly (Farrell and Greig, 2016).

Manyika et al. (2016) take a broader approach to alternative work, notably by not limiting coverage to workers' main job, and find a higher incidence of such working arrangements. They define independent work as that which entails: a high degree of autonomy; payment by task, assignment or sales; and/or a short-term relationship between the worker and the customer. On this basis, they estimate that the independent workforce represents some $20-30 \%$ of the working-age population in the United States and EU-15 countries and that approximately $15 \%$ of independent earners use digital platforms. Thus, the platform (or gig) workforce is relatively small compared to other forms of alternative work arrangements, but it is growing very rapidly.

The shift towards independent work could have economic benefits by raising labour force participation, stimulating consumption, providing opportunities for the unemployed and boosting productivity (Manyika et al., 2016). But these developments in the United States and EU-15 countries also raise concerns about more workers having limited access to income security protections, such as workers' compensation, and not being covered by minimum wage and anti-discrimination laws. Another issue is that independent workers face potential hurdles of reduced access to credit, not being paid for work performed and complex tax filing, licensing and regulatory compliance requirements.

A key issue that arises is whether or not people working in such arrangements are employees. This is key for defining employer responsibilities versus those falling to the employee. In common law countries, such as New Zealand and the United States, courts have distinguished between an employee and an independent contractor in case law (Bryson v Three Foot Six Ltd.). The interpretation of the law can create some uncertainty for online platform companies and those who, as employees or contractors, work for them (Kennedy, 2016). Platform companies are discouraged from helping workers to link with one another for advice or support or for arranging free financial guidance because doing so would increase the chance that courts would find the existence of an employer-employee relationship. Of course, such a finding would be appropriate if there really were such a relationship, but today the outcome is still quite uncertain.

The starting point for the NZ authorities to adapt policies to the development of non-standard work arrangements is to collect data on the number of workers concerned and their characteristics, for example to replicate the U.S Bureau of Labor Statistics' Contingent Worker Survey and/or the Manyika et al. study. The authorities will also need to consider how, if at all, laws and regulations governing the world of paid work should be reformed to allow for non-standard work arrangements and in particular, whether the common-law definition of an employee remains pertinent in all cases.

\section{Adapting to technical change that favours high-skilled workers}

Given ongoing technical progress that is likely to favour high-skilled workers (see Figures 1,2 and 9), young people will need to continue their initial education to higher levels than in the past and in fields that are in demand to have good job prospects. It will be important for the education system to put more emphasis on developing learning skills and personal characteristics, such as the ability to build relationships, curiosity and creativity, and less on acquiring knowledge. Workers will need to upgrade or re-orient their qualifications frequently to adapt to changing labour market requirements. And, more workers than in the past may need to rely on the social safety net to support them as they transition away 
from declining occupations. Insofar as technical progress may result in deteriorating labour market prospects for the low skilled and some of them may not manage to upskill sufficiently to avoid being left behind, it may be necessary to increase redistribution through the tax-transfer system to maintain social cohesion and inclusiveness.

\section{NZ workers' strong information-processing skills should facilitate adjustment to technological progress}

New Zealand workers have strong information-processing skills, especially in literacy and problem solving in a technologically rich environment (Figures 12 and 13), putting them in good stead to adapt to change, such as workplace reorganisation to use digital technologies more productively. According to the PIAAC study (OECD, 2016b), NZ adults' (aged 25-64) average literacy score was the fourth highest among the 29 participating OECD countries or regions, while their average problem-solving score was fifth highest. Moreover, the share of the population with medium to high problem-solving skills (44\%) was equal highest with Sweden. NZ workers' numeracy skills were less outstanding, but still above average, ranking 13th.

Figure 12. Information-processing skills 2012 or $2015^{1}$

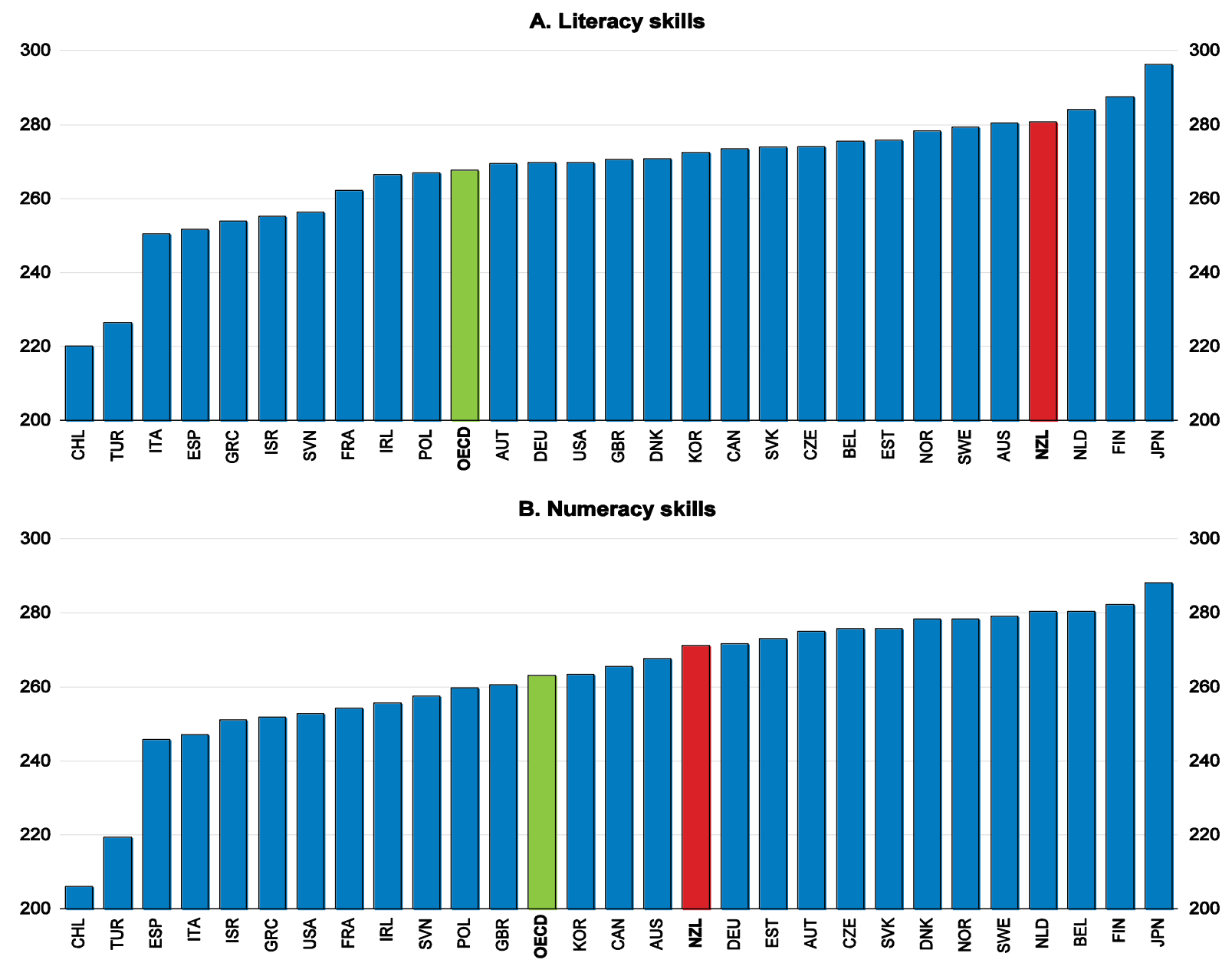

1. For the exact year of reference of the data, see footnote 2 in Figure 2.8. Data indicated as Belgium correspond to Flanders; the United Kingdom is an average of England and Northern Ireland.

Source: OECD Survey of Adult Skills (PIAAC) database (2012 and 2015). 
Figure 13. Proficiency in problem solving in technology-rich environments among adults Percentage of 16-65 year-olds scoring at each proficiency level, 2012 or $2015^{1}$

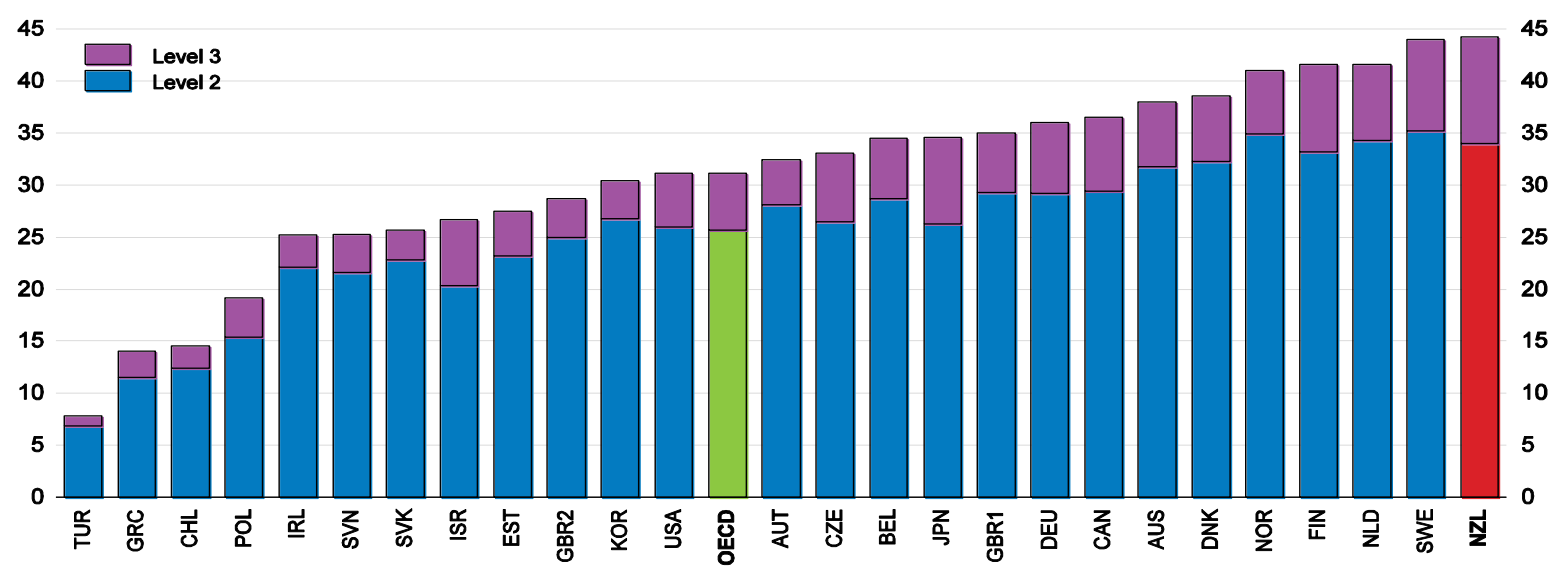

For the exact year of reference of the data, see footnote 2 in Figure 2.8. Data indicated as Belgium correspond to Flanders; GBR1 = England and GBR2 = Northern Ireland.

Source: OECD (2016), Skills Matter: Further Results from the Survey of Adult Skills, Table A2.6; OECD Survey of Adult Skills (PIAAC) database (2012 and 2015).

Workers with stronger information-processing skills are better able to adapt to change. Using past average growth in real GDP per capita as a measure of the pace of economic change, Hanushek et al. (2016) find that returns to information-processing skills (represented by numeracy skills) are higher when there is more rapid economic change. They estimate that a one standard deviation increase in numeracy skills is associated with $19 \%$ higher earnings in New Zealand, slightly below the pooled estimate for the 32 countries in PIAAC (Figure 14). They undertake numerous tests to reject the hypothesis that the result reflects higher per capita growth when the returns to skills are higher rather than the other way around.

\section{Figure 14. Return to numeracy skills across PIAAC countries ${ }^{1}$} 2012 and $2015^{2}$

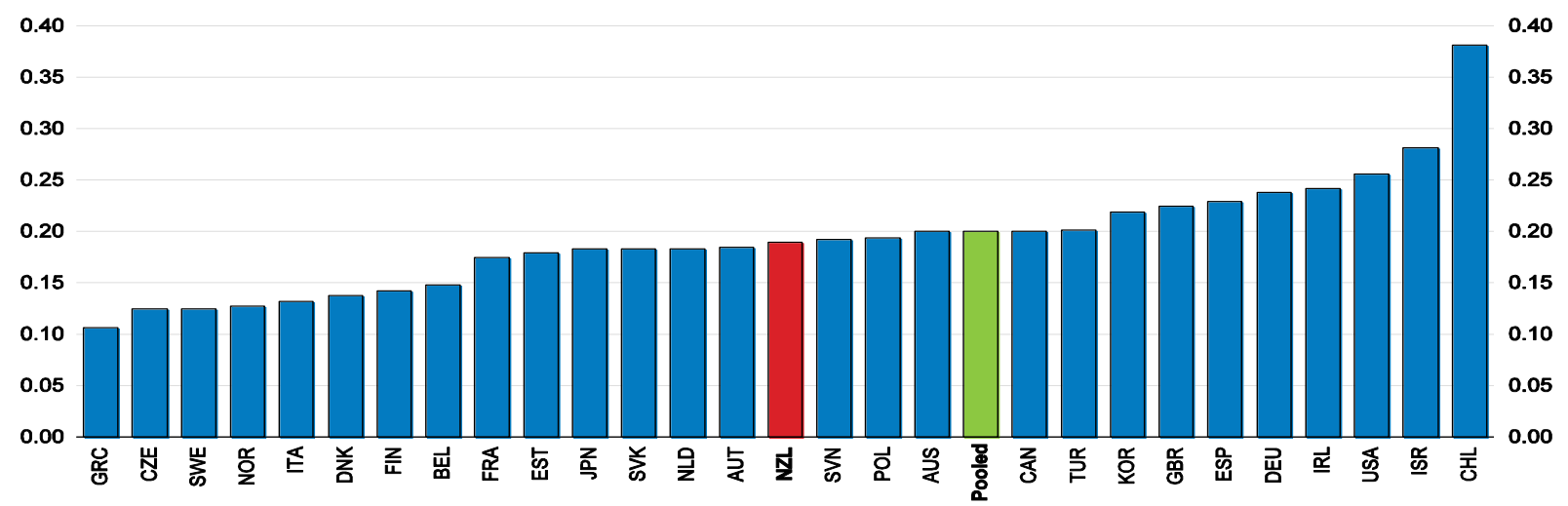

1. Coefficient estimates on numeracy scores (standardised to unit standard deviation within each country) in a regression of log gross hourly wages on numeracy, gender and a quadratic polynomial in actual work experience using a sample of full-time employees aged 35-54. Regressions weighted by sampling weights. The pooled specification includes country fixed effects and gives the same weight to each country.

2. For the exact year of reference of the data, see footnote 2 in Figure 2.8.

Source: E. Hanushek et al. (2016), "Coping with Change: International Differences in the Returns to Skills", NBER Working Paper Series, No. 22657, Figure 1; OECD Survey of Adult Skills (PIAAC) database (2012 and 2015). 
As in most other countries, information-processing skills rise to a peak early in workers' careers and decline subsequently (Figure 15). In New Zealand the peak occurs for the 35-44 year-old age group, which is somewhat later than the OECD average, and the subsequent decline is smaller than average. As a result, the shortfall in older workers' (aged 55-64 years) proficiency levels relative to those of younger workers is smaller than in most other OECD countries. Older workers' proficiency levels rank more highly by international comparison than younger workers' (aged 16-24 years): for example, older workers' average literacy score is second highest among OECD countries, whereas younger workers' average score is only $12^{\text {th }}$ highest. Unfortunately, as these data are a snapshot of proficiency of different age groups at a point in time rather than tracking proficiency of the same age cohort over time, it is not possible to disentangle age effects (i.e., the consequences of growing older), cohort effects (the consequences of being born at different times) and period effects (the consequences of influences that vary through time, such as economic recessions) (OECD, 2016b). New Zealand's stronger relative performance by the older age group in international comparison could reflect environmental factors that are more effective in nurturing skills as people age in New Zealand than in most other countries. Alternatively, these outcomes could reflect faster improvements in education in other countries than in New Zealand.

Figure 15. The age profile of information-processing skills 2012 or $2015^{1}$

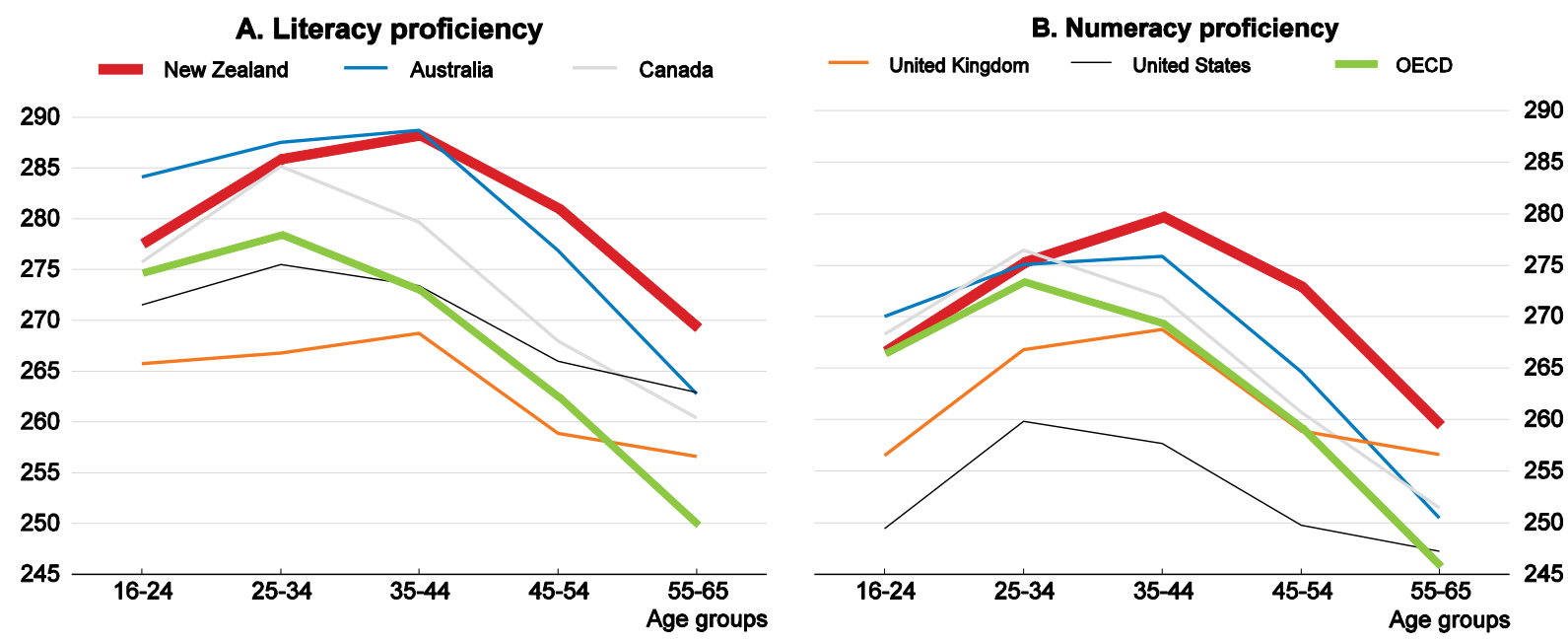

1. For the exact year of reference of the data, see footnote 2 in Figure 2.8. The UK data is composed of England and Northern Ireland.

Source: OECD (2016), Skills Matter - Further Results from the Survey of Adult Skills, Annex A; OECD Survey of Adult Skills (PIAAC) database (2012 and 2015).

A factor that may contribute to older workers' relatively high proficiency levels in New Zealand is the heavy use of skills used in the workplace in everyday life as well (Figure 16). In the workplace New Zealand adults make extensive use of almost all information-processing skills (OECD, 2016b). Use of the five skills surveyed - reading, writing, numeracy, ICT and problem-solving - ranges from the highest among countries that participated in PIAAC for reading to fifth highest for writing. Skills used in everyday life are also the highest on average among PIAAC countries and again rank highly in each of the four skills surveyed (reading, writing, numeracy and ICT). Workers who use their skills more frequently are also likely to have higher wages, even after accounting for differences in educational attainment, skills proficiency and occupation (OECD, 2016b), and to be more satisfied with their jobs than other workers (OECD, 2016c). Controlling for proficiency, greater use of reading, writing and ICT skills is associated with higher hourly labour productivity (ibid). Analysis at the industry level confirms these results, except for writing, and shows that problem-solving skills are also associated with higher productivity. 
Figure 16. Use of information-processing skills 2012 or $2015^{1}$

\section{A. Skills at work}

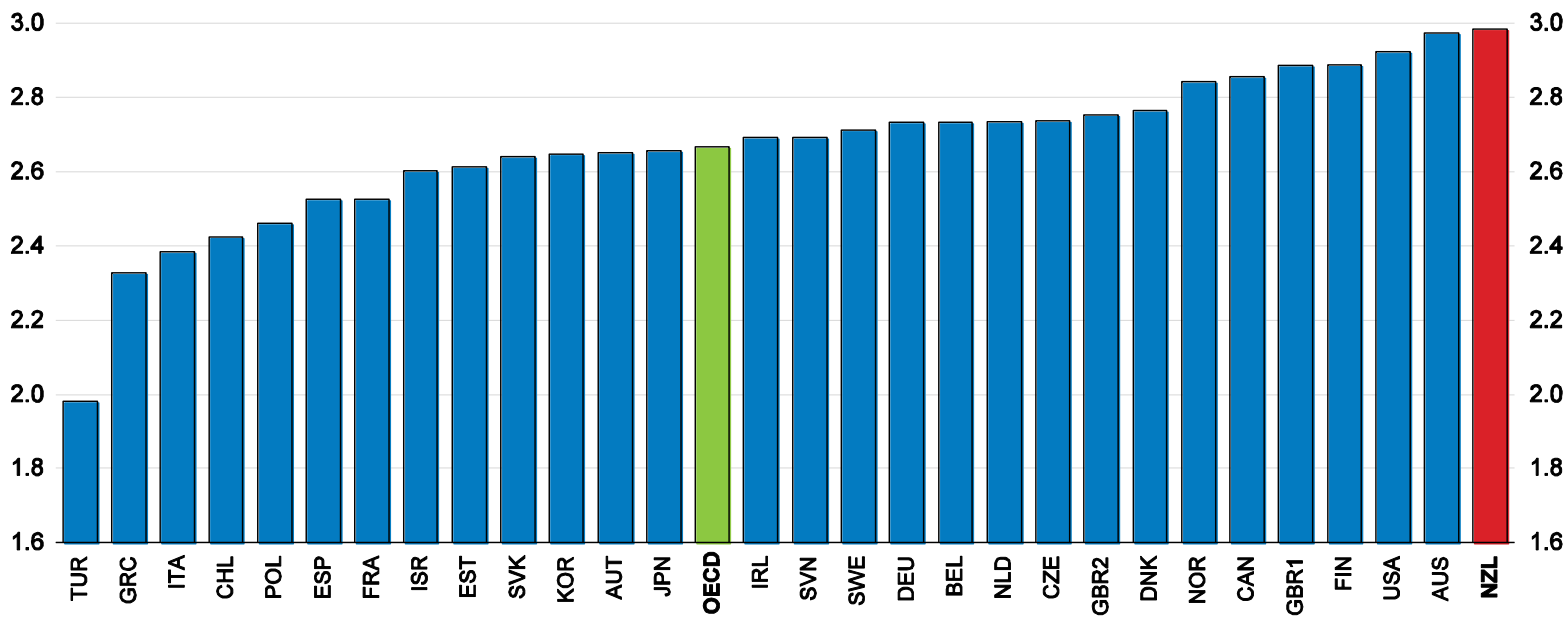

B. Skills used in everyday life

3.0

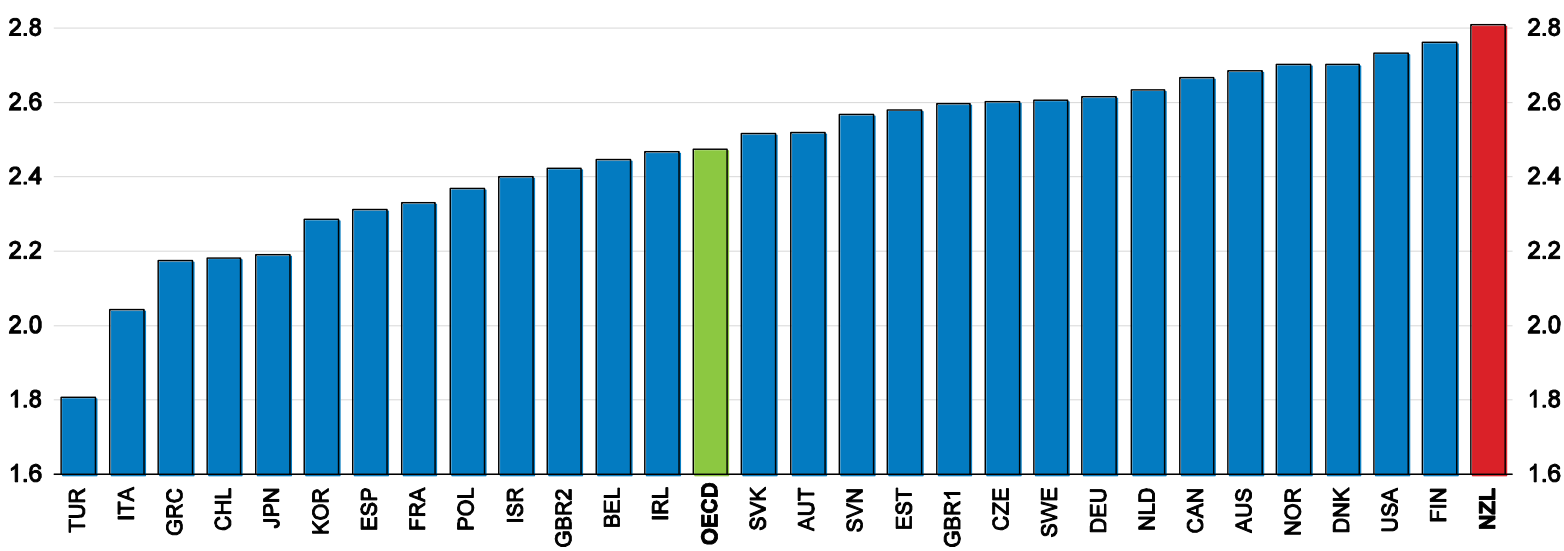

1. For the exact year of reference of the data, see footnote 2 in Figure 2.8. Data indicated as Belgium correspond to Flanders; GBR1 $=$ England and GBR2 $=$ Northern Ireland .

Source: OECD (2016), Skills Matter - Further Results from the Survey of Adult Skills, Annex A; OECD Survey of Adult Skills (PIAAC) database (2012 and 2015).

High skills use in the workplace in New Zealand is partly attributable to the prevalence of highperformance work practices, which include both aspects of work organisation - such as team work, autonomy, task discretion, mentoring, job rotation and applying new learning - and management practices - such as employee participation, incentive pay, training practices and flexibility in working hours (Figure 17, Panel A). High-performance work practices are prevalent in New Zealand in work organisation (Panel B) and, with the exception of incentive-pay schemes, such as bonuses, in management practices (Panel C). Such work practices increase skills use at work. OECD (2016c) finds that, controlling for age, gender, years of education, skills proficiency, industry, firm size and country fixed effects, a one standard deviation increase in the index of high-performance work practices used in the PIAAC study would result in an increase in the various indices of skills use by between 0.58 point for numeracy and 0.68 point for writing and problem-solving at work - approximately half a standard deviation of the dependent variables. 
Figure 17. High-performance work practices 2012 or $2015^{1}$

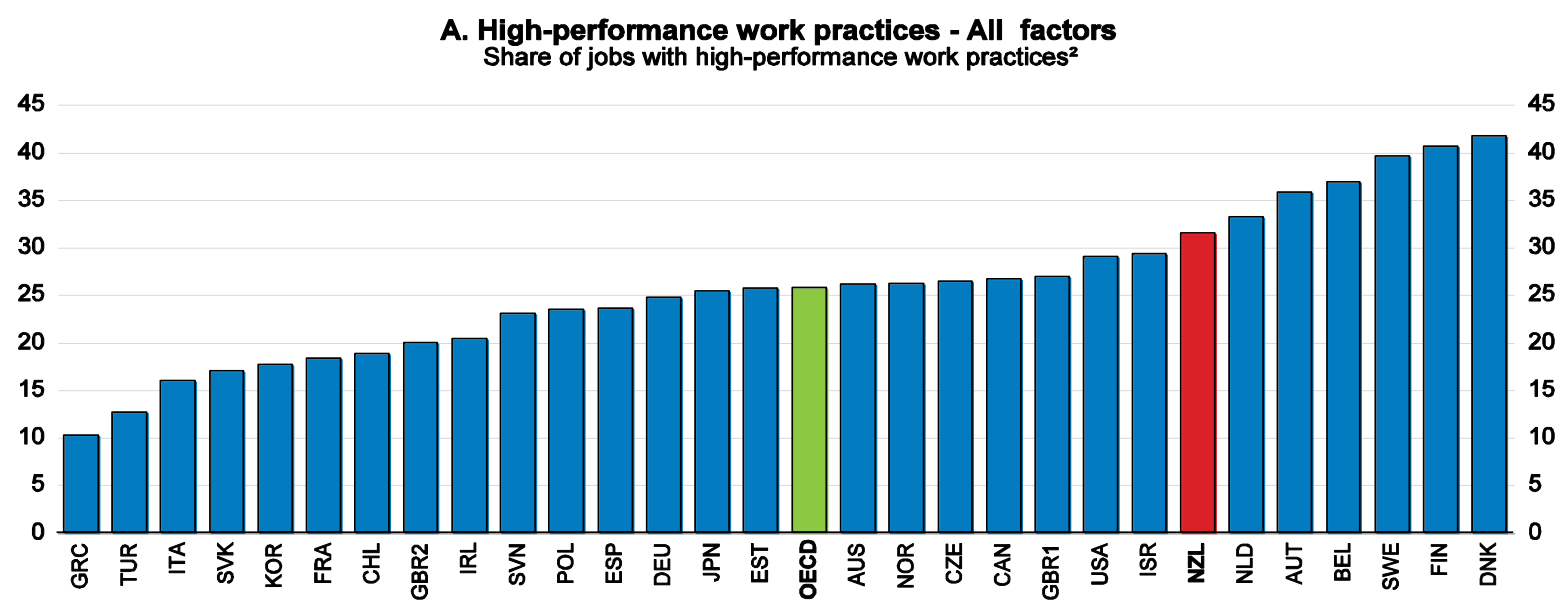

B. High-performance work practices - Work organisation only Share of jobs with high-performance work practices ${ }^{2}$ (in work organisation only)

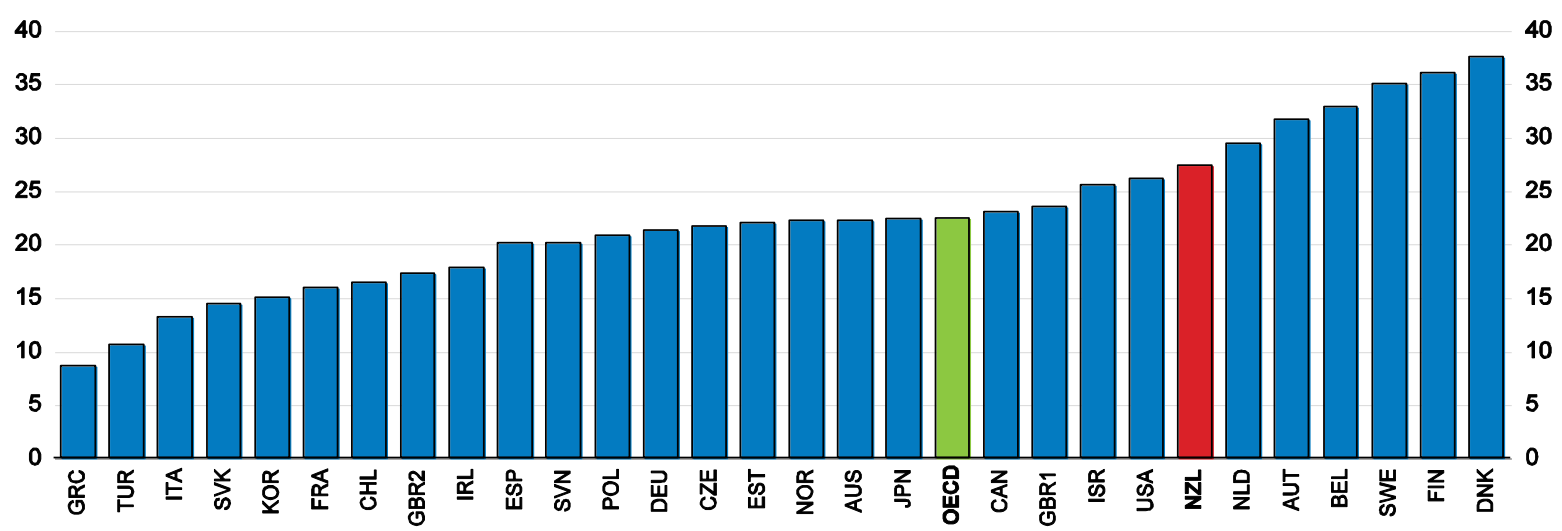

\section{High-performance work practices - Management practices} Prevalence of HPWP management practices ${ }^{3}$

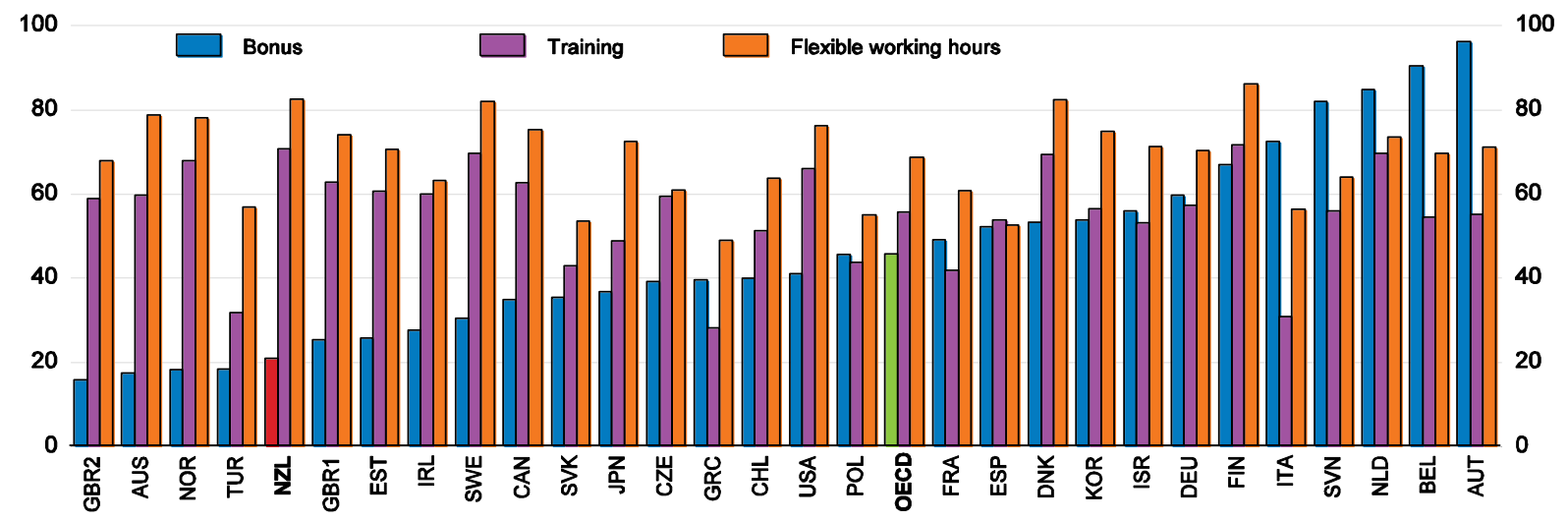

1. For exact year of reference of the data, see footnote 2 in Figure 2.8. Data indicated as Belgium correspond to Flanders; GBR1 = England and GBR2 = Northern Ireland.

2. Share of workers in jobs where the summary HPWP is above the top 25th percentile of the pooled distribution.

3. Share of workers receiving bonuses (bonus), having participated in training over the previous year (training) or enjoying flexibility in working hours (flexible working hours).

Source: OECD (2016), Employment Outlook 2016, Figure 2.10; OECD Survey of Adult Skills (PIAAC) database (2012 and 2015 ). 
The New Zealand government, like many others, is promoting better skills utilisation through workplace innovation. The High-Performance Working Initiative (HPWI) provides business coaching for small- to medium-sized businesses to help improve work practices so as to enhance performance as well as increase employee engagement and satisfaction (OECD, 2016c). While this initiative is very useful for disseminating good practices, it may need to be complemented by management skill development programmes with wider reach, as such skills in New Zealand lag behind best practice (see Barker, 2017), potentially inhibiting the diffusion of high-performance work practices. Incorporating some management elements in non-management tertiary programmes could also help to improve managerial skills.

\section{Increasing educational attainment}

For more young people to be able to succeed in post-secondary education, achievement by the secondary level will need to improve - performance at the secondary level is a strong predictor of success at the tertiary level (OECD, 2016a). The OECD PISA study shows that while achievement stabilised between 2012 and 2015 at levels above the OECD average, it had declined markedly in earlier years (Figure 18). The decline reflects an increased share of low performers (below Level 2) and a reduced share of high performers (levels 5 and 6) (Figure 19). It is not clear why these changes have occurred. Possible explanatory factors include significant changes in the curriculum and qualifications framework, changes in teacher training and development and other factors affecting teaching and learning, such as increases in the use of ability grouping. Māori and Pasifika achievement lags well behind that of the rest of the population (Figure 18 and 20), and the influence of socio-economic background on outcomes, both within and between schools, remains higher than in many countries (Figure 21). Achievement issues are most pronounced in mathematics, where PISA scores are only just above the OECD average and there is a larger tail of poor performers than in the other subjects. Weakness in mathematics achievement is corroborated in the TIMMS study (Mullis et al., 2016), for which the NZ score is below average. Only half of students at year 8 are on a trajectory to reach the required level at year 12 to continue their education at the tertiary level in any field requiring mathematics competence.

Figure 18. New Zealand's average PISA scores have fallen
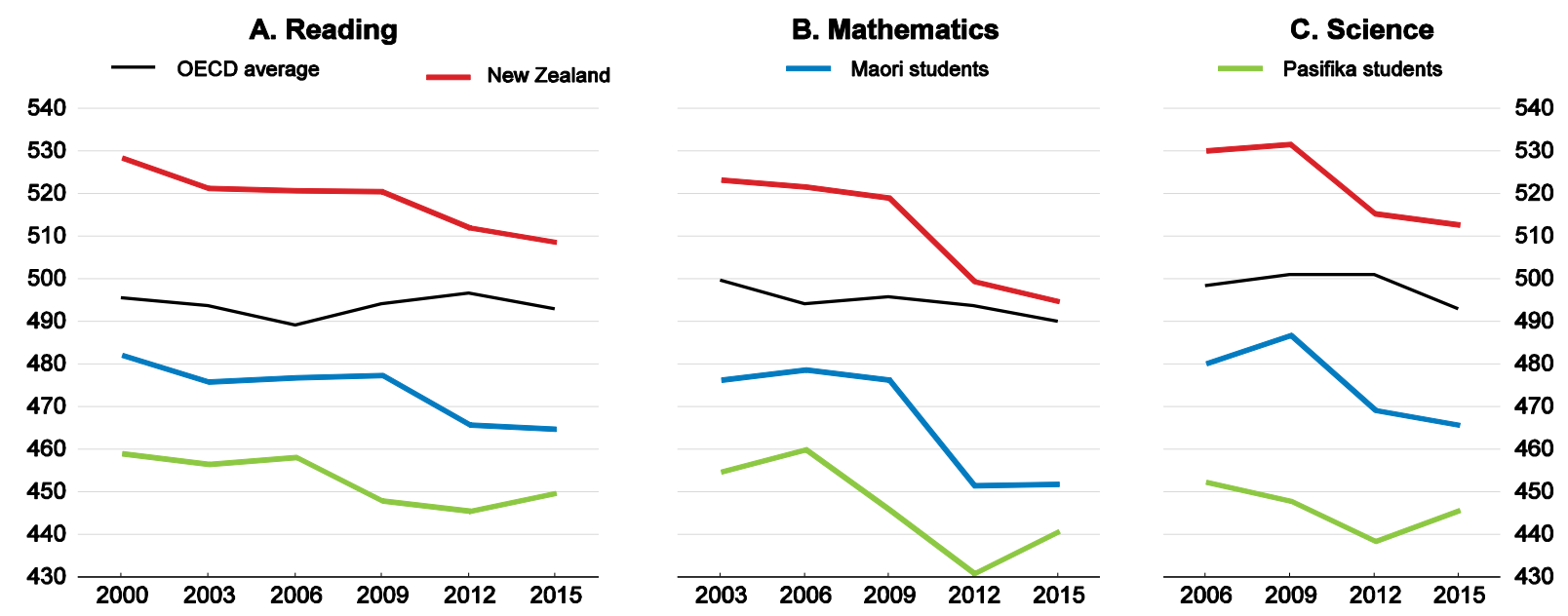

Source: OECD, PISA Results, various years; S. May, J. Flockton and S. Kirkham (2016), PISA 2015 - New Zealand Summary Report, Ministry of Education. 
Figure 19. Percentage of students at each proficiency level ${ }^{1}$

Trends in New Zealand over time and 2015 comparison with the average of countries with similar performance ${ }^{2}$

Low level

A. Reading

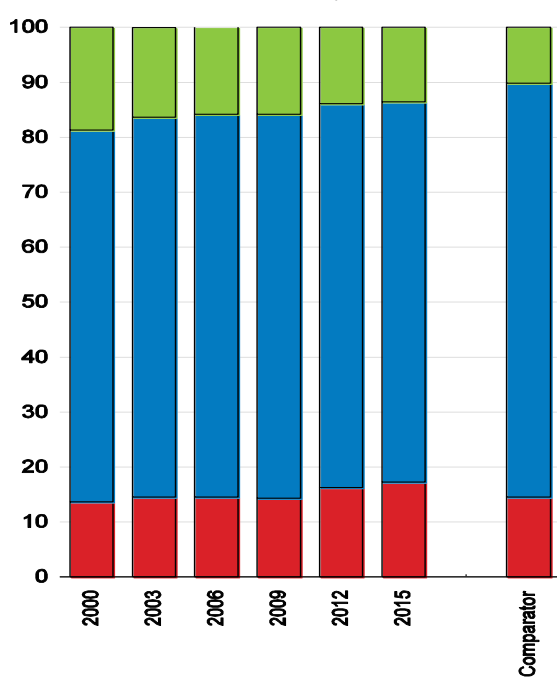

Medium level

B. Mathematlcs

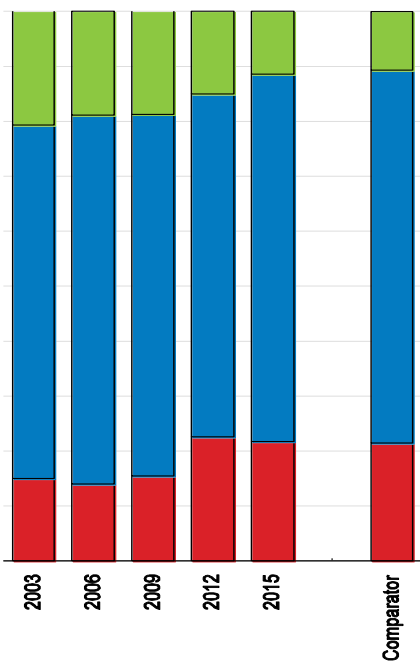

High level

C. Sclence

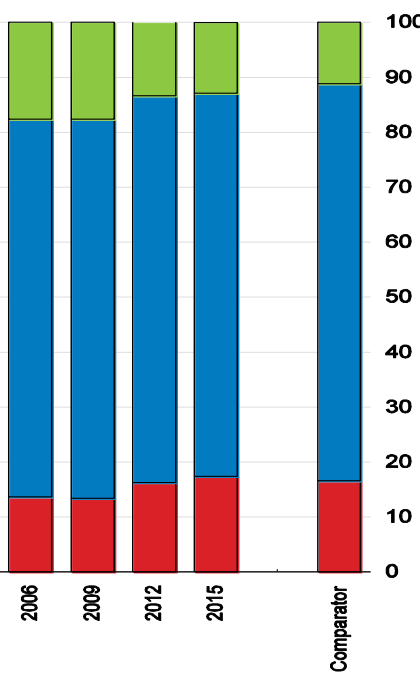

1. Low level is defined as the combination of below level $1 / 1 \mathrm{~b}$, level $1 \mathrm{~b} / 1 \mathrm{a} / 1$; medium level as the sum of level 2 , level 3 and level 4; and high level as level 5 plus level 6.

2. Countries for which scores are not significantly different from New Zealand's are for reading, Germany, Japan, Korea, Macao (China), Netherlands, Norway, Poland and Slovenia; for mathematics, Australia, Austria, Czech Republic, France, Portugal, Russian Federation, Sweden, United Kingdom and Viet Nam; and for science, Australia, Germany, Korea, Netherlands, Slovenia, United Kingdom and Beijing-Shanghai-Jiangsu-Guangdong (China).

Source: OECD, PISA Results, v

arious years.

Figure 20. PISA performance in mathematics, 2015

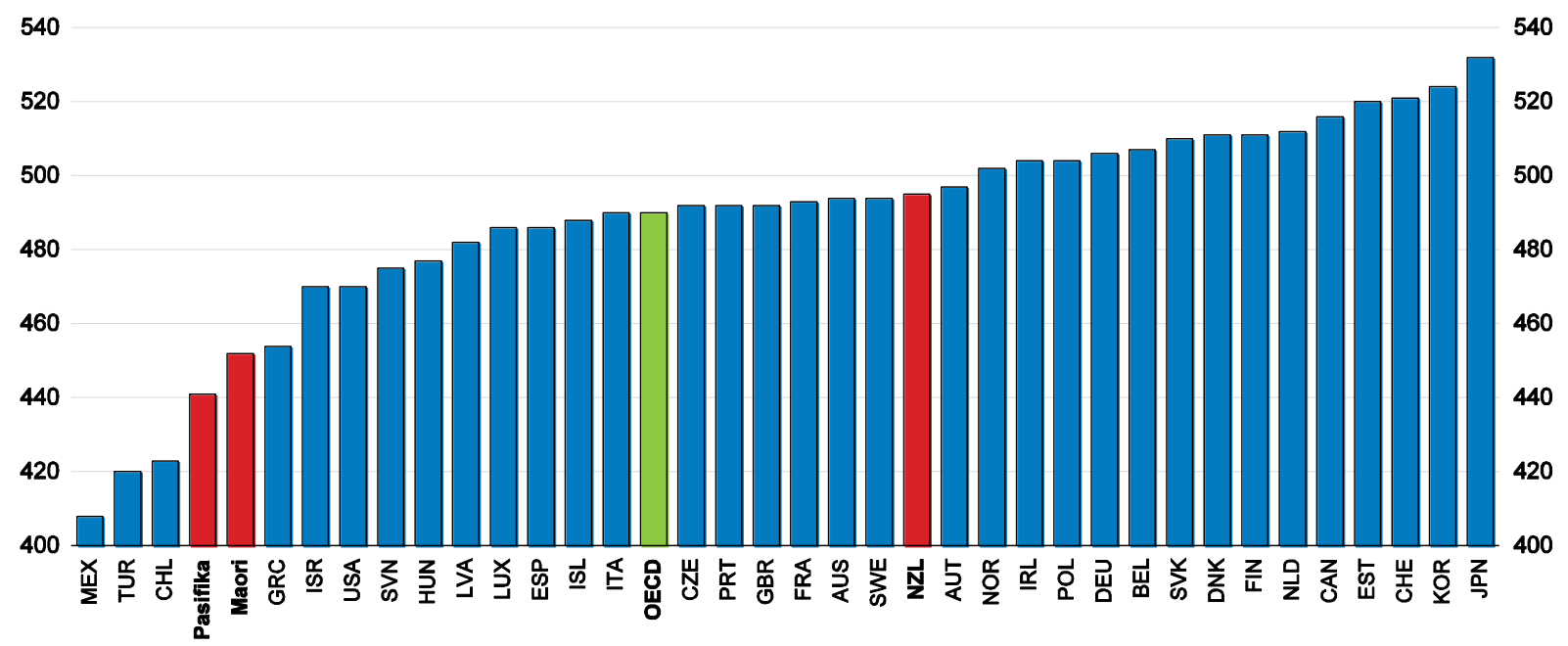

Source: OECD (2016), PISA 2015 Results: Excellence and Equity in Education, Annex B1, Chapter 5; S. May, J. Flockton and S. Kirkham (2016), PISA 2015 - New Zealand Summary Report, Ministry of Education. 
Figure 21. Influence of socio-economic background on PISA scores in mathematics

Variation in student performance explained by socio-economic background, ${ }^{1} 2015$

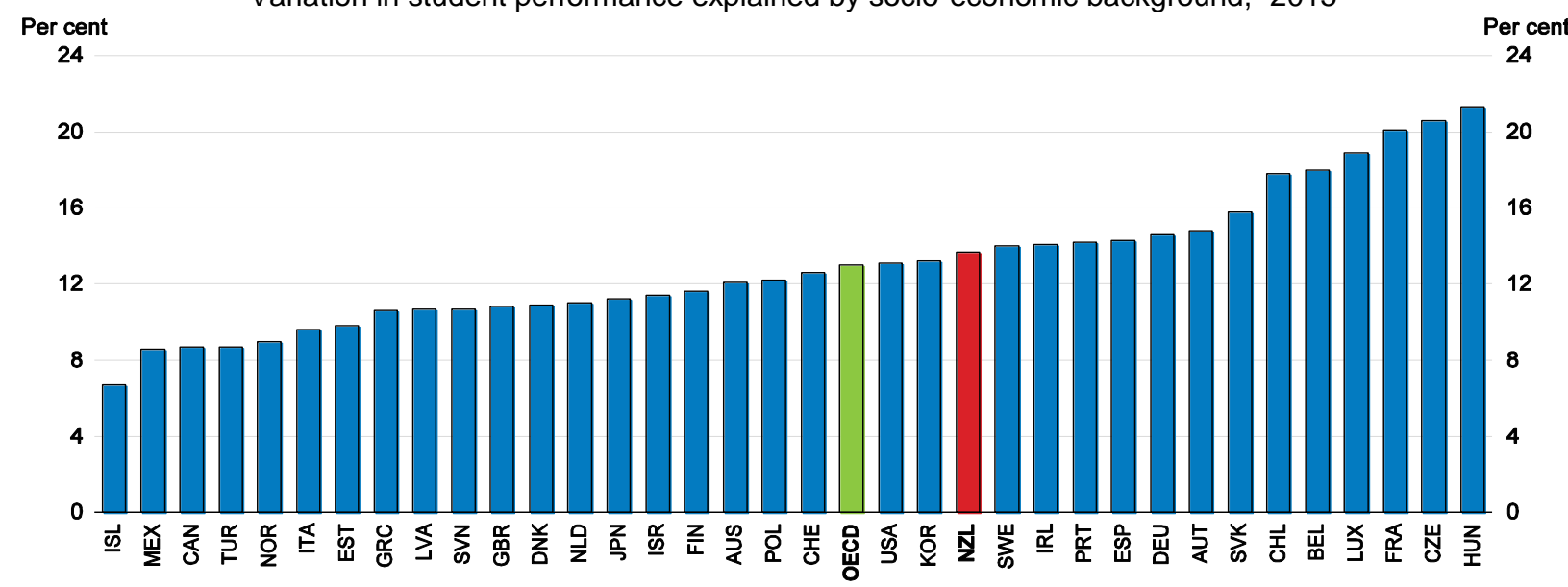

1. PISA index of economic, social and cultural status.

Source: OECD (2016), PISA 2015 Results: Excellence and Equity in Education, Vol. I, Table I.6.3c.

A cornerstone of successive governments' strategies for accelerating the progress of Māori and Pasifika students and those from low socio-economic backgrounds, is to ensure that all pre-school children have access to high-quality early childhood education. Progress has been made in reducing nonparticipation rates for Pasifika and Māori children, from 24\% and 17\%, respectively, in 2000 , to $9 \%$ and $6 \%$ in 2016. Nevertheless, these non-participation rates and those for children from lower socio-economic backgrounds more generally remain significantly higher than for other children. New Zealand's early childhood education regulations ensure the structural foundations for quality. Regulations include high ratios of adults to children and requirements for qualified teachers. As discussed in the last Survey (OECD, 2015a), the government needs to monitor outcomes for all disadvantaged children and, if necessary, move to ensure that increased participation is improving their educational outcomes. Subject to evaluation results, programmes targeting children from lower socio-economic, Māori or Pasifika families that combine good quality early childhood education with parenting support and education should be expanded. There have also been improvements in the rates of students, including Māori and Pasifika, obtaining a National Certificate of Educational Achievement (NCEA) Level 2 or above qualification (an NCEA Level 2 qualification is normally gained in upper secondary school by the end of Year 12 and is considered to be the minimum necessary to give people reasonable opportunities in terms of further education and employment).

Raising teaching effectiveness is the most important in-school lever for enhancing learning (OECD, 2015b; Schleicher, 2016; Hattie, 2008). Enhancing the quality of school leadership is also important (Pont et al, 2008; Robinson et al., 2009; Branch et al., 2012). A range of initiatives is underway to improve teaching effectiveness, including the creation of Communities of Learning in 2014. These are intended to enhance collaboration between schools and improve teaching and leadership expertise in New Zealand's highly devolved school system. Communities of Learning identify their priority achievement challenges; draw on new teaching and leadership roles to lift teaching effectiveness in response to these challenges; and build more coherent student pathways through the education system. As discussed in the last Survey, better use should be made of student achievement data to ensure that all students are performing well. Communities of Learning, recent reforms to professional learning and development, and an ongoing review of initial teacher education should enable further progress in this area. More generally, school funding should fully reflect the additional costs of delivering the curriculum to children from disadvantaged backgrounds and/or with behavioural problems or disabilities. As part of an early learning 
and school funding review, the New Zealand government is currently exploring the mechanism for funding children at greater risk of educational underachievement because of disadvantage.

Communities of Learning should help to ease achievement problems by lifting primary school teachers' capability and confidence in mathematics. By encouraging teachers to work across both primary and secondary settings, Communities of Learning allow specialist secondary school teachers to lead and support effective teaching of mathematics across all the schools in a Community of Learning. Arrangements within Communities of Learning for early intervention to help students falling behind in mathematics should also help.

To lift outcomes in the long term, a systemic approach is necessary to improve the effectiveness of mathematics teaching in primary and intermediate schools. Key elements of such an approach include: raising initial teacher education quality and entry standards (current minimum entry standards for teaching programmes are relatively low); supporting professional learning and development that lifts the capability of current teachers in mathematics; and supporting school leaders to lead a collaborative, data- and evidence-informed teaching culture that emphasises all aspects of the mathematics curriculum.

Options should also be explored to ensure that every pathway through the schooling system enables students to gain at least the minimum skill level needed to support further study and labour market participation in higher-skilled occupations. One of the unintended consequences of a highly devolved education system may be that it is less likely to consistently deliver a core set of skills to each student. In this respect, options should be investigated to reduce over-reliance on same ability grouping (i.e., the streaming of students for all classes, some subjects, or different forms of a subject) and variability in students' levels of exposure to the mathematics curriculum. This could include reviewing minimum numeracy requirements for school qualifications and the minimum education required by all school leavers as well as examining options for schools to access guidance and professional learning and development on the effective use of mixed ability grouping strategies.

\section{Reducing qualifications and field-of-study mismatches}

Adapting to technical change entails not just acquiring higher levels of education and skills, but obtaining those that are in demand in the labour market. New Zealand may have some problems in this regard. Qualifications and field-of-study mismatches, which occur when workers have qualifications that are greater or less than required for their jobs or in a different field, are more common than for any other participant country in the PIAAC study (Box 1; Figure 22). Most qualifications mismatch is overqualification, and most over-qualified workers are also field-of-study mismatched. In New Zealand, the proportion of overqualified workers who are also field mismatched is higher $\left(8^{\text {th }}\right.$ highest) than in most other OECD countries that participated in the PIAAC study (Figure 23, Panel A). Workers who are fieldof-study mismatched often hold qualifications in fields where the labour market is oversupplied, obliging them to settle for a job outside their field of study that requires a lower qualification than they hold (Montt, 2015). In New Zealand, the proportion of field mismatched workers who are also overqualified is the third highest among OECD countries that participated in the PIAAC study (Panel B). 


\section{Box 1 Measuring qualifications, field-of-study and skills mismatches}

Mismatches in the OECD PIAAC study (OECD, 2016b) are measured as follows:

Qualifications mismatch arises when workers have an educational attainment that is higher or lower than that required for their job. This is assessed in relation to workers' answer to the question about the usual qualifications, if any, "that someone would need to get (their) type of job if applying today". The answer to this question is used as each worker's qualifications requirement and compared to their actual qualifications to identify mismatch.

Field-of-study mismatch occurs when workers are employed in a different field from that in which they have specialised. The matching is based on a list of occupations (at the 3-digit ISCO classification) that are considered as an appropriate match for each field of study.

Skills mismatch arises when workers have higher or lower information processing skills proficiency (such as in literacy or numeracy) than required for their job. To assess skill proficiency requirements for a job, workers were asked whether they feel that they "have the skills to cope with more demanding duties than those they are required to perform in their current job" and whether they feel they "need further training to cope well with their present duties". Workers are classified as well matched in a domain if their proficiency score is between some minimum and maximum score observed among workers who answered "no" to both questions in the same occupation and country. In the PIAAC study, workers are over-skilled in a domain if their score is higher than the $95^{\text {th }}$ percentile of self-reported well-matched workers; they are under-skilled in a domain if their score is lower than the $5^{\text {th }}$ percentile of self-reported well-matched workers. It should be noted that the PIAAC study does not measure all forms of skills mismatch - it focuses on information processing skills in the domains assessed but, for example, leaves out mismatch related to job-specific skills or that involve generic skills. 
Figure 22. Qualifications and field-of-study mismatch'

Percentage of mismatched workers, by type of mismatch, 2012 and $2015^{2}$

\section{A. Qualification mismatch}

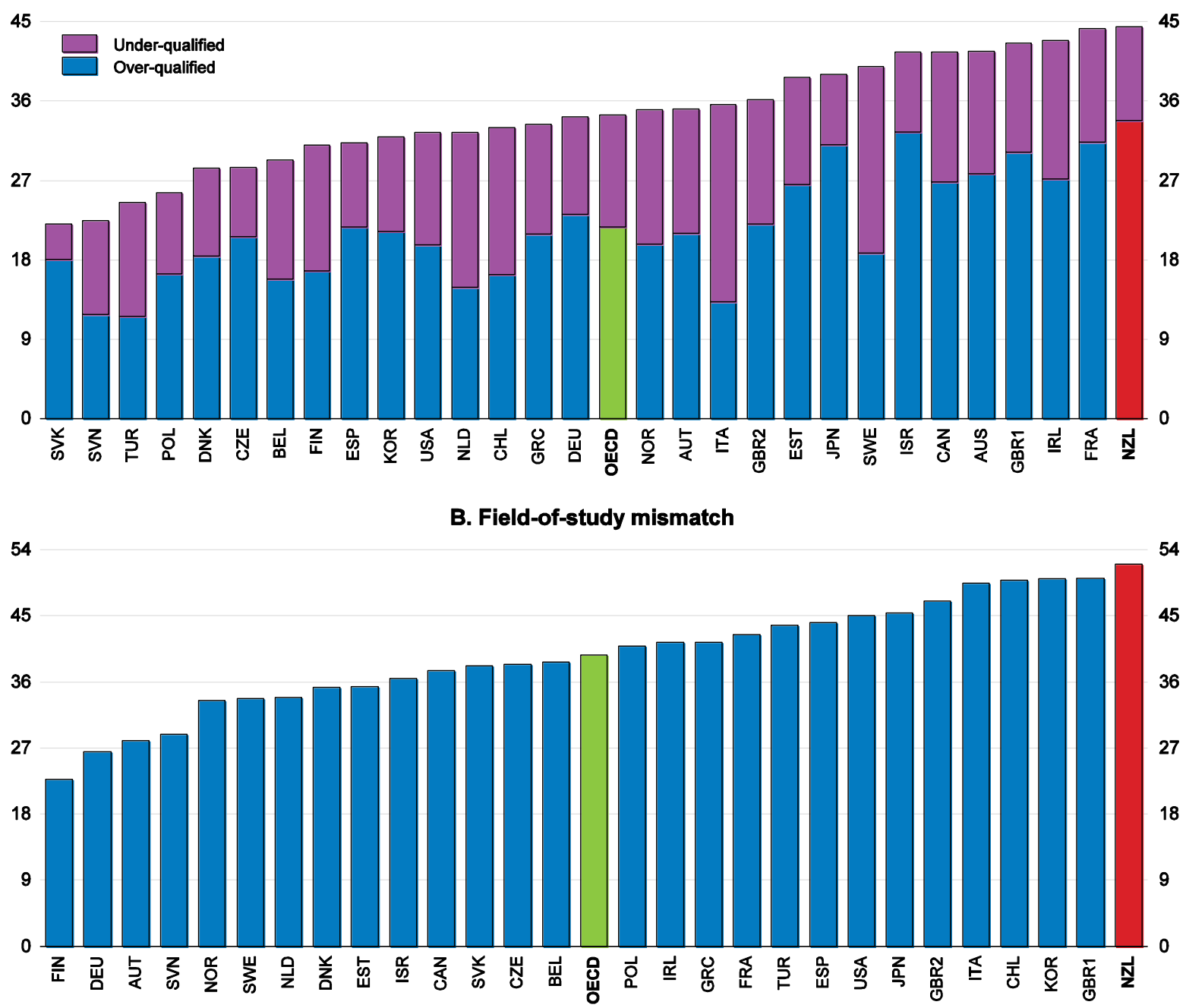

1. Qualifications mismatch occurs when a worker has a higher or lower level of qualification than is required for his/her job. Fieldof-study mismatch occurs when a worker has a qualification in a different field than required for his/her job.

2. For the exact year of reference of the data, see footnote 2 in Figure 2.8. Data indicated as Belgium correspond to Flanders: GBR1 = England and GBR2 = Northern Ireland.

Source: OECD (2016), Skills Matter: Further Results from the Survey of Adult Skills, Figure 5.7; OECD Survey of Adult Skills (PIAAC) database (2012 and 2015). 
Figure 23. Overlap of over-qualification and field-of-study mismatch 2012 and $2015^{1}$
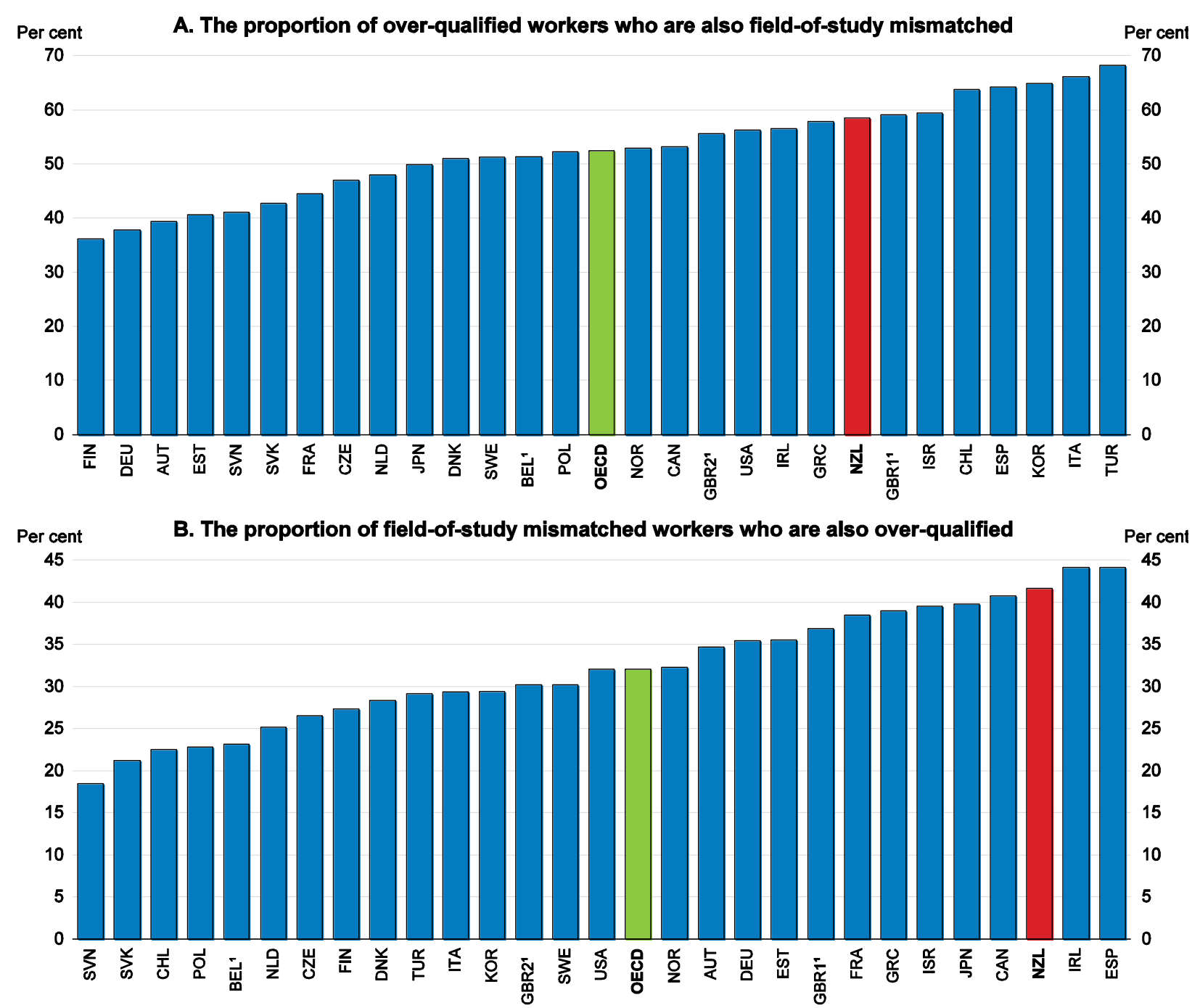

1. For the exact year of reference of the data, see footnote 2 in Figure 2.8. Data indicated as Belgium correspond to Flanders; GBR1 = England and GBR2 = Northern Ireland.

Source: OECD (2016), Skills Matter: Further Results from the Survey of Adult Skills, Figures 5.8a \& 5.8b; OECD Survey of Adult Skills (PIAAC) database (2012 and 2015).

In a dynamic economy, some level of mismatch is inevitable (just as is some unemployment). Skills and qualification requirements for jobs are constantly evolving. Job tasks change in response to technological and organisational change, the demands of customers and the evolution of the labour supply (OECD, 2016b). Young people leaving education and people moving from unemployment into employment, for example, may take jobs that do not fully match their qualifications and qualifications and skills. As mismatches can reduce productivity and wages as well as worker satisfaction (OECD, 2016b; see below), the public policy objective is to ensure that policies are not inimical to efficient matching.

It should be emphasised that the measures of mismatch discussed in this paper are at the individual level, i.e., on the outcomes of allocating individuals to jobs and adapting job tasks to workers' skills or qualifications. These measures do not address imbalances in the aggregate supply of and demand for individuals with particular skills or qualifications. For example, a high degree of over-qualification does 
not mean that there must be an oversupply of highly qualified workers in the labour market. While labourmarket imbalances have an effect on the prevalence and type of mismatches observed at the individual level (Montt, 2015), it is not automatic (OECD, 2016b). It is possible, for example, for a high degree of over-qualification to co-exist with shortages of highly qualified workers in the labour market.

Over-qualified workers in New Zealand earn $14 \%$ less than well-matched workers with the same qualifications and skills proficiency, the same hourly earnings penalty as the average for OECD countries (OECD , 2016b). As in other countries, this wage penalty is greater than for the other forms of mismatch (i.e., field of study and information processing skills). After controlling for over-qualification and overskilling, field-of-study mismatch does not have a significant further effect on wages in New Zealand (and reduces wages by only $3 \%$ on average across OECD countries). NZ workers employed outside their field only suffer a significant wage penalty when they are also overqualified, as almost half of them are.

According to econometric evidence presented in OECD (2016b), by far the most important factor that contributes to the relatively high incidence of over-qualification in New Zealand is the preponderance of very small firms (1-10 employees). Firm size may have this effect, because it is a proxy for the quality of human-resource policies: larger companies are better at screening candidates and at understanding how over-qualification may affect job satisfaction and productivity (OECD, 2016b). Larger firms may also have larger internal labour markets through which workers can be transferred to better matched jobs inside the firm. The next most important factor contributing to the high rate of NZ over-qualification is the greater incidence of part-time work than in most other OECD countries, which also increases field-of-study mismatch and over-skilling. Part-time jobs, which often have lower skill requirements, may attract overqualified, field-of-study mismatched and/or over-skilled candidates because these jobs are more compatible with family responsibilities or are preferred over unemployment. OECD (2016b) also found that part-time employees are more likely to be field-of-study mismatched in New Zealand than full-time employees, but that small-firm employment is not a significant explanatory factor of field mismatch.

While New Zealand is always likely to have a high incidence of over-qualified workers owing to its small economy and the associated preponderance of employment in very small firms, steps could be taken to reduce such mismatch. Given that most over-qualified workers are field-of-study mismatched, reducing field mismatches could help to reduce over-qualification mismatches. New Zealand's comparatively high overall rate of field-of-study mismatch reflects some combination of qualification shares being tilted towards fields in which mismatch tends to be high internationally and mismatches in specific fields being high. As in most other countries, field mismatch is highest for "humanities, languages and arts" and lowest for "social sciences, business and law" (Table 6). Relative to the OECD average, NZ mismatches are particularly high in "teacher training and education science" and in "humanities, languages and arts", and especially low in "agriculture and veterinary". This could be a sign that, relative to other countries, more workers in New Zealand have qualifications in the former two fields and not enough have qualifications in the latter field in relation to labour market demand. The fact that in New Zealand the overall mismatch rate $52.0 \%$ which is a weighted average of field mismatches, is close to the simple average of field mismatches $(52.7 \%)$, whereas the overall mismatch rate for the OECD average $(41.9 \%)$ is well below the average of field mismatches (48.2\%) indicates that the distribution of workers across fields in New Zealand is more weighted towards those with high mismatch rates than is the case in most other countries. 
Table 6. Prevalence of field-of-study mismatch by field

\begin{tabular}{|c|c|c|c|c|c|c|c|c|c|}
\hline & & & Field-c & dy mis & tch by fie & of study, & cent & & \\
\hline & 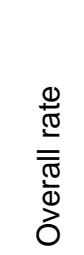 & 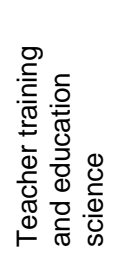 & 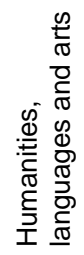 & 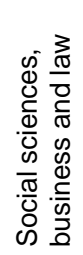 & 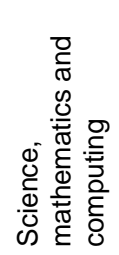 & 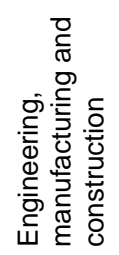 & 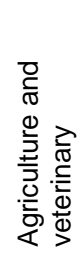 & 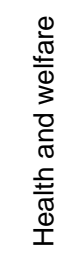 & $\begin{array}{l}\stackrel{\infty}{0} \\
\stackrel{\infty}{\infty} \\
\stackrel{\infty}{\infty}\end{array}$ \\
\hline New Zealand & 52.0 & 56.3 & 90.7 & 27.3 & 79.5 & 36.2 & 55.8 & 32.8 & 43.9 \\
\hline England (UK) & 50.1 & 40.6 & 87.3 & 27.3 & 76.7 & 37.5 & 83.4 & 24.7 & 57.9 \\
\hline Korea & 50.1 & 33.7 & 72.9 & 26.3 & 84.0 & 44.1 & 85.9 & 39.4 & 22.9 \\
\hline Chile & 49.9 & 40.9 & 83.6 & 22.0 & 73.9 & 41.7 & 39.9 & 43.4 & 42.7 \\
\hline Italy & 49.4 & 48.2 & 75.6 & 18.8 & 76.9 & 34.0 & 82.2 & 25.1 & 47.3 \\
\hline Northern Ireland (UK) & 47.0 & 40.5 & 87.4 & 20.3 & 74.5 & 41.6 & 90.7 & 22.3 & 63.1 \\
\hline Japan & 45.3 & 72.1 & 85.8 & 27.0 & 59.5 & 38.2 & 79.6 & 24.1 & 32.1 \\
\hline United States & 45.0 & 49.7 & 73.6 & 24.5 & 71.7 & 33.2 & 71.4 & 35.1 & 46.1 \\
\hline Spain & 44.1 & 40.1 & 80.7 & 26.8 & 71.3 & 37.6 & 43.2 & 30.4 & 35.1 \\
\hline Turkey & 43.8 & 24.3 & 76.4 & 33.6 & 80.8 & 41.5 & 48.8 & 32.6 & 40.5 \\
\hline France & 42.5 & 37.6 & 68.5 & 25.6 & 72.9 & 35.9 & 64.6 & 35.0 & 40.9 \\
\hline Country average & 41.9 & 46.3 & 76.5 & 23.5 & 71.2 & 34.4 & 70.9 & 30.5 & 38.6 \\
\hline Greece & 41.4 & 36.1 & 75.0 & 16.8 & 68.6 & 44.4 & 78.1 & 37.8 & 16.6 \\
\hline Ireland & 41.4 & 29.1 & 76.5 & 23.1 & 79.5 & 31.0 & 83.1 & 28.6 & 34.3 \\
\hline Poland & 40.9 & 38.2 & 65.6 & 19.0 & 79.6 & 34.4 & 65.6 & 24.8 & 47.0 \\
\hline Flanders (Belgium) & 38.7 & 28.5 & 76.3 & 20.8 & 68.1 & 32.1 & 90.2 & 31.1 & 25.1 \\
\hline Czech Republic & 38.3 & 35.9 & 77.9 & 22.5 & 69.7 & 32.2 & 77.4 & 39.4 & 52.2 \\
\hline Slovak Republic & 38.2 & 26.9 & 80.1 & 21.0 & 66.0 & 28.3 & 84.1 & 22.8 & 36.3 \\
\hline Canada & 37.5 & 30.0 & 77.1 & 19.2 & 62.6 & 26.0 & 57.3 & 32.2 & 41.3 \\
\hline Israel & 36.5 & 34.9 & 69.2 & 23.6 & 46.0 & 35.7 & 55.9 & 30.2 & 60.0 \\
\hline Estonia & 35.3 & 30.9 & 61.5 & 23.7 & 47.5 & 32.4 & 75.8 & 23.5 & 40.7 \\
\hline Denmark & 35.2 & 40.0 & 71.7 & 19.9 & 51.0 & 29.0 & 63.7 & 19.8 & 41.8 \\
\hline Netherlands & 33.9 & 30.0 & 72.7 & 17.4 & 59.1 & 39.2 & 69.4 & 32.6 & 37.1 \\
\hline Sweden & 33.7 & 27.7 & 71.1 & 30.8 & 54.7 & 30.6 & 64.9 & 23.8 & 27.2 \\
\hline Norway & 33.5 & 21.6 & 71.0 & 19.6 & 66.1 & 35.2 & 91.9 & 21.7 & 27.4 \\
\hline Slovenia & 28.8 & 19.2 & 44.3 & 20.0 & 51.6 & 29.6 & 63.9 & 16.3 & 32.8 \\
\hline Austria & 28.0 & 25.9 & 60.8 & 21.8 & 49.3 & 28.6 & 76.5 & 14.7 & 25.6 \\
\hline Germany & 26.4 & 31.9 & 55.6 & 17.4 & 51.6 & 29.2 & 54.5 & 23.2 & 18.0 \\
\hline Finland & 22.8 & 31.2 & 52.7 & 16.7 & 41.5 & 21.1 & 55.0 & 14.7 & 18.1 \\
\hline
\end{tabular}

Source: OECD calculations based on the Survey of Adult Skills, PIAAC (2012 and 2015).

Field mismatches could be lower if more NZ students sought qualifications in less crowded fields, where job prospects are better. The NZ government has recently created Internet sites (e.g., Compare Study Options) to help students and their parents become better informed about labour market prospects in different fields of study, although this information would be more easily accessible if the sites were consolidated (NZPC, 2017). These services need to be complemented by better careers education and guidance in schools. The New Zealand Productivity Commission (2017, p. 360) concludes that "...careers education and guidance in schools is highly variable, frequently delivered far too late, and at its worst appears not to reach some students. Schools tend to provide information to students rather than ensuring that students develop the skills to manage their own career pathways." The approach to schools-based career education should be reformed, as recommended by the Commission (p. 304), so that students develop the skills and knowledge to make effective decisions about their study options and careers pathways. Following a comprehensive review, the government is proposing to transfer Careers New Zealand's functions into the Tertiary Education Commission (TEC) to exploit the TEC's ability to 
work with tertiary providers and employers so that they can provide better careers information to schools regarding the skills needs of the labour market. In this context, the authorities are also exploring how to make it easier to share careers resources and expertise across schools and Communities of Learning.

NZ students' capacity to choose less crowded fields would be augmented if more had obtained the skills needed to enter these fields by the end of secondary school. As noted above, weak mathematics skills limit students' choices, which may encourage more of them to enter crowded fields such as "teacher training and education science" or "humanities, languages and arts", where mathematics prerequisites are most often limited or non-existent.

It may also be worth reviewing New Zealand's career-focused education, as is happening in many other countries, to ensure that it is in tune with the changing labour-market demands resulting from digitalisation. In the United States, for example, the manufacturing sector requires many more workers who know how to use robotics equipment and can navigate across a variety of technologies than are in the education pipeline (Giffi et al., 2015). To help to bridge these skills gaps, career-focused education is being developed. An example is the six-year high school-community college programme founded by IBM in 2011 in which 300 partner companies work with 60 local schools to shape curricula that will educate students up to a two-year associate's degree. More generally, having the skills to work with new technologies is likely to be critical to access good jobs. Increasingly, students will need to graduate with a mix of soft skills, such as problem solving and communication, and basic technical skills such as technology and mathematics.

\section{Bolstering lifelong learning}

People need to acquire new skills throughout their working lives to meet evolving labour market demands. This may entail moderate educational investments to remain productive in an occupation as its skill requirements evolve or more substantial investments to train for a different occupation, sometimes necessitated by the demise of a worker's current occupation. Most often, these educational investments will involve part-time formal education (i.e., planned education provided in formal educational institutions that normally constitutes a continuous ladder of full-time education for children and young people) and/or non-formal education (i.e., sustained educational activity that does not correspond exactly to the definition of formal education). Formal and/or non-formal education can play an important role in helping to develop and maintain key information processing skills and to acquire other knowledge and skills throughout life. It is crucial to provide and ensure access to organised learning opportunities for adults beyond initial formal education, especially for workers who need to adapt to changes throughout their careers and have difficulty succeeding in the labour market (OECD, 2013).

New Zealand is starting from a good position in terms of adult (aged 25-64) participation in formal and non-formal education, which is the highest among the countries that participated in the PIAAC study (Figure 24, Panel A). This performance reflects high participation in both the formal and non-formal components (OECD, 2016a). As in most other countries, men and women participate at roughly equal rates. Participation in New Zealand and other countries is correlated with educational attainment, information-processing skills (literacy, numeracy and problem solving in a technology-rich environment) and the frequency of their use (Panels B, C and D). Yet, the gaps in participation rates between those with high educational attainment, reading skills and/or use of reading skills in everyday life and those with the opposite characteristics is smaller in New Zealand than in most other countries, reflecting high participation rates by international comparison for people with low attainment, literacy skills and/or use of reading skills. As in other countries, proficiency levels and educational attainment have a mutually reinforcing effect on participation. While those with high literacy skills or high tertiary attainment in New Zealand are 1.6-1.7 times more likely to participate than people with the opposite characteristics, this ratio rises to 2.2 for those with high literacy skills and education attainment relative to those with the 
opposite characteristics, which is far below the OECD average ratio of 4.0. Despite relatively below average hours of participation in non-formal education in New Zealand, overall time invested in such education is above the OECD average owing to the high participation rates (OECD, 2016a). Factors that contribute to high participation in formal education include open access to tertiary education for those aged over 20, highly subsidised courses, student support (loans and income-tested allowances) and low income tax rates, which boost after-tax returns on education investments.

Figure 24. Participation in formal/non-formal education 25-64 year-olds, 2012 or $2015^{1}$
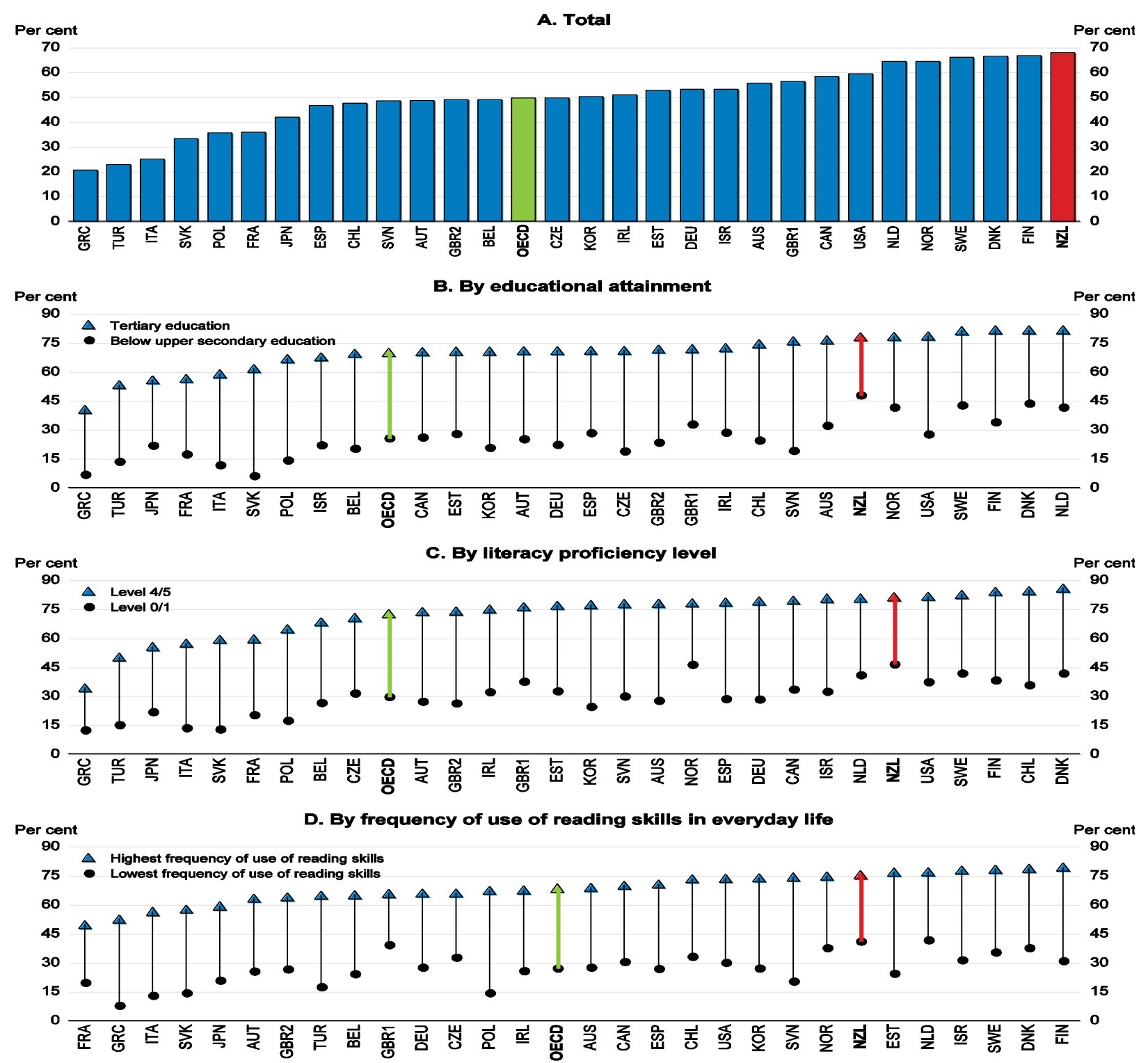

1. For the exact year of reference of the data, see footnote 2 in Figure 2.8. Data indicated as Belgium correspond to Flanders; GBR1 = England and GBR2 = Northern Ireland.

Source: OECD (2016), Education at a Glance 2016: OECD Indicators, Indicators C6; OECD Survey of Adult Skills (PIAAC) database (2012 and 2015). 
Access to part-time formal education is important for workers beyond the typical age of enrolment to be able to upgrade or re-orientate their qualifications, as such workers usually have family responsibilities that rule out full-time study. For example, $68-78 \%$ (depending on the level of studies) of tertiary enrolments at ages above typical enrolment ages (20-29) are part time in New Zealand, compared with part-time enrolments rates of 37-64\% for all age groups (OECD, 2016a). These part-time enrolment shares at ages above typical enrolment ages are well above the OECD average (38-47\%). They should facilitate further education for workers who need to upgrade their skills to perform more tasks that are complementary to machines or to move into new fields, some of which may not have existed before. For people in middle-skilled jobs, this will often involve upgrading to tertiary qualifications to move into other middle-skilled occupations that digitalisation has made more productive, such as health technicians and paralegals, as is occurring in the United States (Holzer, 2015).

Increasing online delivery of tertiary education could help to increase the number of people obtaining tertiary qualifications, especially mid-career workers. Goodman et al. (2016) find that the introduction of the Georgia Institute of Technology's Online Masters in Computer Science increased its overall formal enrolment, expanding the pool of students. This degree programme is of the same quality as the in-person equivalent, leads to the same qualification and costs less than one-sixth of the price for out-of-state students. These authors find that demand for this online degree is driven by mid-career Americans, most of whom would not otherwise pursue further education. There are a number of programmes taught online in New Zealand. However, for them to develop more, the government would need to make tertiary institution funding arrangements more flexible. While such programmes are not explicitly discouraged at the moment, they are likely financially unattractive to providers facing an Effective Full-time Tertiary Student (EFTS) quantity cap, as they would displace existing courses that attract higher fees (NZPC, 2017). Existing rules make it difficult to introduce a new course at a low fee, and financially risky to lower the price of an existing course (ibid). Failure to make it more attractive for NZ universities to offer online courses could result in foreign universities' prestigious courses, such as the one studied by Goodman et al., crowding out local institutions' programmes (ibid).

While the provision of training is high on average, it is uneven across different professions, with those in lower skilled jobs less likely to receive learning and development opportunities. Employers (particularly of lower skilled workers) may underinvest in training that builds transferable skills for fear that their employees leave before training investments have been amortised. This problem is likely to be more so in small firms, which have smaller internal labour markets, are more credit constrained and less wellmanaged than larger companies. While training bonds, which require workers to reimburse their employer for part of the costs of training that they received if they quit or are fired before a certain date, may be an effective solution for higher-paid employees, such bonds are less likely to be effective for lower-paid employees as their more limited financial resources could make contract enforcement challenging. If training investments enhance lower skilled workers' labour market prospects, the government will benefit through lower social benefit costs and higher tax revenues. In these circumstances, there may be a role for government subsidies or regulatory interventions to increase such investments in lower skilled workers towards the socially optimal level. This will be all the more so if faster rates of technical change result in more people having to upgrade skills to remain in employment. Among best practices for such incentives, OECD (2017a) recommends that they should minimise administrative burdens, focus on the least skilled and SMEs, be flexible, result in certified learning outcomes and be regularly monitored and evaluated.

\section{Reducing information-processing skills mismatch}

Technical change is likely to result in increasingly rapid changes in job-skill requirements, aggravating information-processing skills mismatches (as well as the qualification and field-of-study mismatches discussed above). This would reduce labour productivity. Controlling for the overlap between components of qualification and (literacy) skills mismatch and for product market competition, 
Adalet McGowan and Andrews (2015a) find that a higher share of over-skilled workers who are wellmatched in terms of their qualification is negatively correlated with labour productivity, reflecting a negative impact on allocative efficiency - over-skilling reduces the extent to which higher-skilled workers are employed by the most productive firms (Table 7, row 7). This negative impact on allocative efficiency also occurs when over-skilled workers are also over-qualified, offsetting the benefit to within-firm productivity on industry productivity (row 2). Their results also suggest that being over-skilled but wellmatched by qualifications may have a more adverse effect on productivity than being over-qualified but well matched by skills, for which there is no significant effect (row 3). They also find that there is a negative effect on productivity of under-qualification and that it is mainly driven by under-qualified workers who are well-matched in terms of skills (row 6). The main channel for this effect is resource misallocation. Finally, they find that there is a negative relationship between under-qualification and within-firm productivity that is entirely driven by workers who are both under-qualified and under-skilled (row 4).

\section{Table 7. Mismatch and labour productivity in OECD countries: controlling for the overlap between the} components of qualification and skills mismatch

\begin{tabular}{|c|c|c|c|}
\hline & (1) & (2) & (3) \\
\hline & $\begin{array}{l}\text { Weighted } \\
\text { Productivity }\end{array}$ & $\begin{array}{l}\text { Allocative } \\
\text { Efficiency }\end{array}$ & $\begin{array}{l}\text { Within-firm } \\
\text { Productivity }\end{array}$ \\
\hline $\begin{array}{l}\text { 1.Over-qualified and under- } \\
\text { skilled }\end{array}$ & $\begin{array}{c}-0.0322^{*} \\
(0.017)\end{array}$ & $\begin{array}{l}-0.0263 \\
(0.023)\end{array}$ & $\begin{array}{l}-0.0059 \\
(0.022)\end{array}$ \\
\hline $\begin{array}{l}\text { 2. Over-qualified and over- } \\
\text { skilled }\end{array}$ & $\begin{array}{l}0.0157 \\
(0.010)\end{array}$ & $\begin{array}{c}-0.0126^{\star * *} \\
(0.004)\end{array}$ & $\begin{array}{c}\mathbf{0 . 0 2 8 2}^{\star *} \\
(0.011)\end{array}$ \\
\hline $\begin{array}{l}\text { 3. Over-qualified and well- } \\
\text { matched (skill) }\end{array}$ & $\begin{array}{r}-0.0032 \\
(0.009)\end{array}$ & $\begin{array}{l}-0.0003 \\
(0.006)\end{array}$ & $\begin{array}{l}-0.0029 \\
(0.005)\end{array}$ \\
\hline $\begin{array}{l}\text { 4. Under-qualified and under- } \\
\text { skilled }\end{array}$ & $\begin{array}{l}-0.0166 \\
(0.020)\end{array}$ & $\begin{array}{l}0.0151 \\
(0.015)\end{array}$ & $\begin{array}{c}-0.0317^{\star *} \\
(0.014)\end{array}$ \\
\hline $\begin{array}{l}\text { 5. Under-qualified and over- } \\
\text { skilled }\end{array}$ & $\begin{array}{l}0.0093 \\
(0.018)\end{array}$ & $\begin{array}{l}0.0044 \\
(0.017)\end{array}$ & $\begin{array}{l}0.0048 \\
(0.023)\end{array}$ \\
\hline $\begin{array}{l}\text { 6. Under-qualified and well- } \\
\text { matched (skill) }\end{array}$ & $\begin{array}{c}-0.0200^{* * *} \\
(0.004)\end{array}$ & $\begin{array}{c}-0.0191^{\star \star \star} \\
(0.005)\end{array}$ & $\begin{array}{l}-0.0009 \\
(0.006)\end{array}$ \\
\hline $\begin{array}{l}\text { 7. Over-skilled and well- } \\
\text { matched (qualification) }\end{array}$ & $\begin{array}{c}-0.0207^{* * *} \\
(0.004)\end{array}$ & $\begin{array}{c}-0.0129^{\star * *} \\
(0.004)\end{array}$ & $\begin{array}{l}-0.0078 \\
(0.005)\end{array}$ \\
\hline $\begin{array}{l}\text { 8. Under-skilled and well- } \\
\text { matched (qualification) }\end{array}$ & $\begin{array}{l}0.0046 \\
(0.004)\end{array}$ & $\begin{array}{l}-0.0040 \\
(0.003)\end{array}$ & $\begin{array}{l}0.0086 \\
(0.005)\end{array}$ \\
\hline Herfindahl index & $\begin{array}{l}-3.3932^{\star * *} \\
(1.067)\end{array}$ & $\begin{array}{c}-2.8125^{\star \star *} \\
(0.677)\end{array}$ & $\begin{array}{l}-0.5807 \\
(0.513)\end{array}$ \\
\hline $\begin{array}{l}\text { Adjusted } R^{2} \\
\text { Observations }\end{array}$ & $\begin{array}{l}0.916 \\
205\end{array}$ & $\begin{array}{c}0.704 \\
205\end{array}$ & $\begin{array}{c}0.936 \\
205\end{array}$ \\
\hline
\end{tabular}

1. The dependent variables are as defined in (1) of Adalet McGowan and Andrews (2015), computed for 2007. All specifications include country and industry fixed effects and are clustered by country. Observations are weighted by industry size-number of firms. Robust standard errors in parentheses. ${ }^{* * *}$ denotes statistical significance at the $1 \%$ level, ${ }^{* *}$ significance at the $5 \%$ level, * significance at the $10 \%$ level.

2. Under- (over-) qualified workers refer to the percentage of workers whose highest qualification is lower (higher) than the qualification they think is necessary to get their job today. Under- (over-) skilled workers refer to the percentage of workers whose scores are higher than that of the minimum (maximum) skills required to do the job, defined as the 10th (90th) percentile of the scores of the well-matched workers in each occupation and country.

Source: M. Adalet McGowan and D. Andrews (2015), "Labour Market Mismatch and Labour Productivity; Evidence from PIAAC Data", OECD Economics Department Working Papers, No. 1209, OECD Publishing, Paris.

As Adalet McGowan and Andrews conduct their analysis using industry-level labour productivity indicators constructed from firm-level data, they are obliged to use a wider measure of skills mismatch (their cut-off points for workers with well-matched literacy skills are the $90^{\text {th }}$ and $10^{\text {th }}$ percentiles of skills of self-reported well-matched workers) than OECD (2016b), where analysis is conducted at the country level. Literacy skills mismatch on this measure is $28 \%$ in New Zealand, compared with an OECD average 
of $26 \%$ (Figure 25). Most mismatch entails over-skilling, as in other countries, but there is also a relatively high share of under-skilling mismatch in New Zealand by international comparison.

\section{Figure 25. Percentage of workers with literacy skills mismatch ${ }^{1}$}

\section{2 and $2015^{2}$}

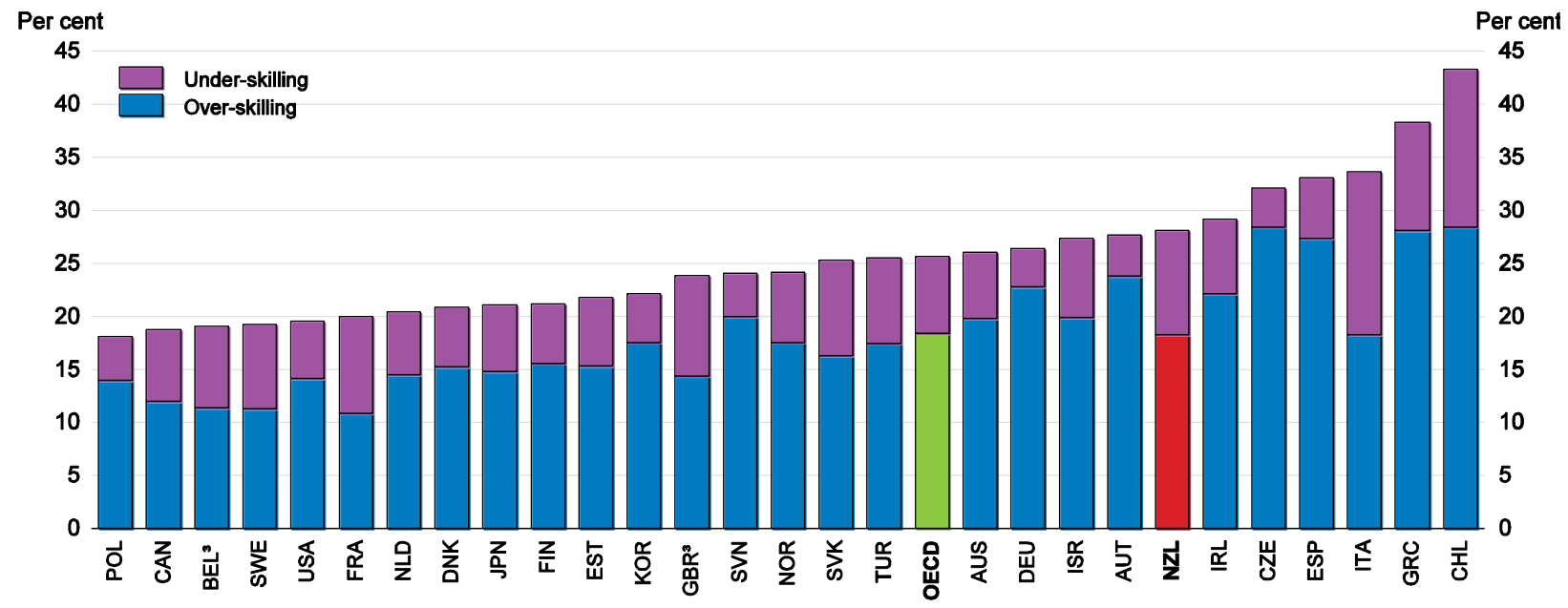

1. The figure shows the percentage of workers who are either over- or under- skilled, for a sample of 11 market industries: manufacturing; electricity, gas, steam and air conditioning supply; water supply; construction; wholesale and retail trade; transportation and storage; accommodation and food service activities; information and communication; real estate activities; professional, scientific and technical activities, and administrative and support service activities. In order to abstract from differences in industrial structures across countries, the 1-digit industry level mismatch indicators are aggregated using a common set of weights based on industry employment shares for the United States. Skills mismatch occurs when a worker's skills are higher than the 90th percentile or lower than the 10th percentile of workers with self-reported well-matched skills.

2. For the exact year of reference, see footnote 2 in Figure 2.8.

3. Data for Belgium correspond to Flanders and data for the United Kingdom to England and Northern Ireland.

Source: M. Adalet McGowan and D. Andrews (2017), "Skills Mismatch, Productivity and Policies in New Zealand: Evidence from PIAAC", OECD Economics Department Working Papers, No. 1403; OECD calculations based on the Survey of Adult Skills (PIAAC) (2012 and 2015).

Adalet McGowan and Andrews (2017) estimates that reducing literacy skills mismatch in New Zealand to the best practice minimum could increase industry labour productivity by $7 \%$ through gains in allocative efficiency (Figure 26; Box 2). This is one of the larger potential gains among OECD countries ( $7^{\text {th }}$ out of 28 countries), reflecting the fact that skills mismatches in New Zealand are relatively large. 
Figure 26. Counterfactual productivity gains from reducing skills mismatch ${ }^{1}$ Simulated gains to allocative efficiency from lowering skills mismatch to the best practice

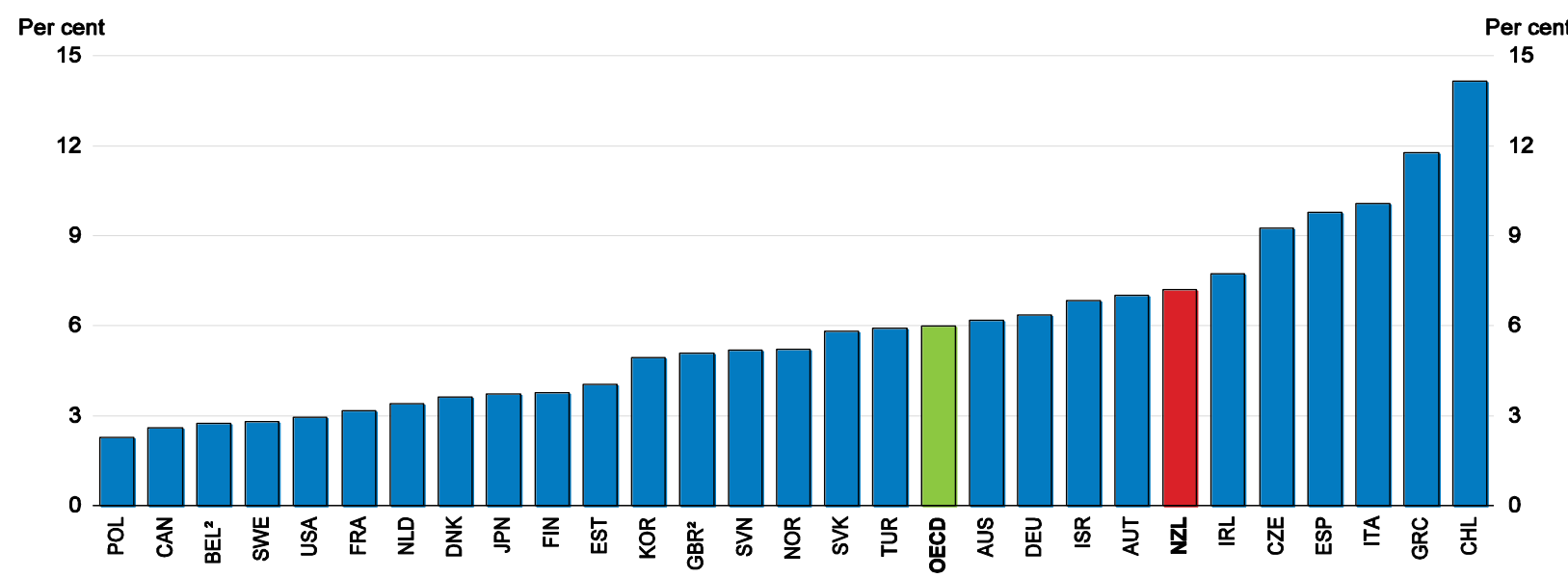

1. The chart shows the difference between the actual allocative efficiency and a counterfactual allocative efficiency based on lowering the skills mismatch in each country to the best practice. 1-digit industry level mismatch indicators are aggregated using a common set of weights based on the industry employment shares for the United States. The estimated coefficient of impact of mismatch on productivity is based on a sample of 19 countries for which both firm level productivity and mismatch data are available. The estimated gains to allocative efficiency for the other countries should be interpreted with caution to the extent that they are not included in the econometric analysis due to insufficient productivity data.

2. Data for Belgium correspond to Flanders and data for the United Kingdom to England and Northern Ireland.

Source: M. Adalet McGowan and D. Andrews (2017), "Skills Mismatch,, Productivity and Policies in New Zealand: Evidence from PIAAC", OECD Economics Department Working Papers, No. 1403; OECD calculations based on the Survey of Adult Skills (PIAAC) (2012 and 2015).

\section{Box 2. Skills mismatch, productivity and policies in New Zealand: evidence from PIAAC}

Adalet McGowan and Andrews (2017) extends the authors' earlier analysis (Adalet McGowan and Andrews, $2015 \mathrm{a}$ and $2015 \mathrm{~b}$ ) to New Zealand. They use industry-level productivity data and define skills mismatch as occurring when an individual has literacy skills above the $90^{\text {th }}$ percentile or below the $10^{\text {th }}$ percentile of the distribution of skills for people in the same occupation (defined at the one-digit level) who say that they are well matched. The strategy for extending the analysis to New Zealand is to apply the coefficient estimates from the cross-country analysis linking mismatch to productivity. It is not possible, however, to calculate to what extent skills mismatch can explain crosscountry productivity gaps for New Zealand due to a lack of publically available firm-level productivity data.

The main criticism of the skills mismatch indicator used in this analysis is that it uses one-digit occupation codes because of sample size, thus assuming that all jobs with the same occupation code have the same skill requirements. Another potential criticism concerns the validity of workers' self-assessment of whether they are over-skilled, underskilled or well matched. However, the OECD measure partially addresses this criticism by correcting false mismatches through the use of proficiency scores as described above.

To assess the role of policy settings in explaining skills mismatch, the following cross-country specification is estimated:

$$
S M M_{i, c}=\Phi\left(\delta_{1}+\delta_{2} I_{i, c}+\delta_{3} P_{c}+\delta_{4} C_{c}+\epsilon_{i, c}\right)
$$

where SMM is a measure of whether individual $i$ in country $\mathrm{c}$ is over- or under-skilled, I denotes a vector of individual characteristics, $\mathrm{P}$ denotes country-specific policies and $\mathrm{C}$ denotes country-specific control variables, including total national income (for more information on I and P, see Adalet McGowan and Andrews (2017)).

The estimation of this equation treats policies as exogenous factors affecting mismatch, but there may be reason to be concerned about endogeneity. Causation is difficult to establish given data limitations: i) the data are available only at one point in time; and ii) due to high correlations between the policy variables, the baseline analysis includes 
the policy variables one at a time. Nevertheless, a number of robust correlations between policy variables and skills mismatch emerge.

Table 8 (above) reports the baseline results of the pooled regressions that explore the effects of different policyrelated factors on skills mismatch obtained from the estimation of the above equation. The different specifications control for a similar set of individual and job characteristics, but the estimated coefficients are not reported for the sake of brevity. To the extent that skills mismatch is related to productivity through both within-firm and between-firm factors (see Adalet McGowan and Andrews, 2015a), it is important to consider policies and factors that impose frictions to the efficient reallocation of labour, restrict the entry of more productive firms and prevent the exit of less productive firms as potential determinants of skills mismatch. While education policies clearly matter, these links between mismatch and productivity through the reallocation channel suggest that a wider range of policies could affect mismatch.

These coefficients are then used to calculate the probability of mismatch evaluated at the value of the policy setting in New Zealand and individual characteristics. Finally, the potential gains to productivity from policy reforms that reduce the probability of skills mismatch are calculated.

Table 8. The effect of policy-related factors on skills mismatch

Marginal effects

\begin{tabular}{|c|c|c|c|c|c|}
\hline & $(1)$ & (2) & (3) & $(4)$ & (5) \\
\hline \multicolumn{6}{|c|}{ Dependent variable: 1 if the individual is mismatched, 0 otherw ise } \\
\hline Panel A: Framew ork policies & $\begin{array}{l}\text { Employment } \\
\text { protection } \\
\text { legislation for } \\
\text { permanent } \\
\text { w orkers }\end{array}$ & $\begin{array}{l}\text { Employment } \\
\text { protection } \\
\text { legislation for } \\
\text { temporary } \\
\text { w orkers } \\
\end{array}$ & $\begin{array}{l}\text { Product market } \\
\text { regulation }\end{array}$ & $\begin{array}{l}\text { Cost of closing a } \\
\text { business }\end{array}$ & \\
\hline \multirow{2}{*}{ Policy-related factors } & $0.043^{\star *}$ & $0.021^{\star *}$ & $0.042^{* *}$ & $0.006^{* *}$ & \\
\hline & $(0.008)$ & $(0.003)$ & $(0.010)$ & $(0.001)$ & \\
\hline Number of observations & 76183 & 76183 & 74224 & 76183 & \\
\hline pseudo-R2 & 0.012 & 0.012 & 0.01 & 0.013 & \\
\hline Panel B: Housing policies & $\begin{array}{c}\text { Transaction } \\
\text { costs } \\
\end{array}$ & Rent control & $\begin{array}{c}\text { Tenant-landlord } \\
\text { regulations }\end{array}$ & $\begin{array}{l}\text { Cost of obtaining } \\
\text { a building permit }\end{array}$ & $\begin{array}{l}\text { Responsiveness } \\
\text { of housing supply }\end{array}$ \\
\hline \multirow{2}{*}{ Policy-related factors } & $0.007^{* * *}$ & $0.017^{\star *}$ & $0.021^{\star *}$ & $0.001^{* *}$ & $-0.051^{\star *}$ \\
\hline & $(0.001)$ & $(0.003)$ & $(0.003)$ & $(0.000)$ & $(0.010)$ \\
\hline Number of observations & 66863 & 66529 & 69002 & 76183 & 58390 \\
\hline pseudo-R2 & 0.011 & 0.011 & 0.012 & 0.009 & 0.014 \\
\hline Panel C: Other policies & $\begin{array}{c}\text { Coverage rate of } \\
\text { collective } \\
\text { bargaining } \\
\text { agreements } \\
\end{array}$ & $\begin{array}{l}\text { Participation in } \\
\text { lifelong learning } \\
\text { (PIAAC data) }\end{array}$ & Managerial quality & & \\
\hline \multirow{2}{*}{ Policy-related factors } & $0.001^{\star *}$ & $-0.002^{* *}$ & $-0.002^{* *}$ & & \\
\hline & $(0.000)$ & $(0.000)$ & $(0.000)$ & & \\
\hline Number of observations & 71819 & 76183 & 76183 & & \\
\hline pseudo-R2 & 0.011 & 0.012 & 0.015 & & \\
\hline
\end{tabular}

Notes: See Table A1 of Adalet McGowan and Andrews (2017) for detailed explanations of the policy variables. Estimates from logit regressions. Values are marginal effects. The coefficients correspond to the impact of a change in the explanatory variable on the probability of mismatch at the mean of the independent variables. Each column in each panel includes one policy-related variable at a time. Regressions include as controls age, marital and migrant status, gender, level of education, firm size, contract type, a dummy for working full-time and working in the private sector. Robust standard errors in parentheses. ${ }^{* * *}$ denotes statistical significance at the $1 \%$ level, ${ }^{* *}$ significance at the $5 \%$ level, ${ }^{*}$ significance at the $10 \%$ level.

Source: OECD calculations based on the Survey of Adult Skills (2012 and 2015).

In New Zealand most public policies that affect the probability of skills mismatch are near bestpractice, but there are some areas with room for improvement, notably housing policies (Figure 27). The biggest problem in this area is the relatively low long-run price elasticity of new housing supply, which is 
only one third of the best practice level in the United States (Andrews et al., 2011). This has had a clear impact on house prices in recent years, making it more difficult for workers to move to a better matched job where they would be more productive. While geographical factors influence supply responsiveness, these are not as important in New Zealand as in more densely populated countries. In terms of policy influences, land-use regulations (zoning) have severely limited densification and expansion of the urban area, notably in Auckland, New Zealand's largest and fastest growing city, and approval processes for making land available for residential construction are cumbersome. Another important constraint on the supply of new housing is the availability of necessary infrastructure, such as roads, water reticulation and sewage and storm water drainage. In Auckland, where excess demand pressures are greatest, investments in such infrastructure to service higher-density developments have lagged behind demand, with the result that some densification authorised in the new Urban Plan may not be possible until the necessary infrastructure becomes available, which could be many years away. Land-use regulations that restrict where certain types of firms may be located may also make it more difficult for workers to find a wellmatched job.

\section{Figure 27. The probability of skills mismatch and policies ${ }^{1}$}

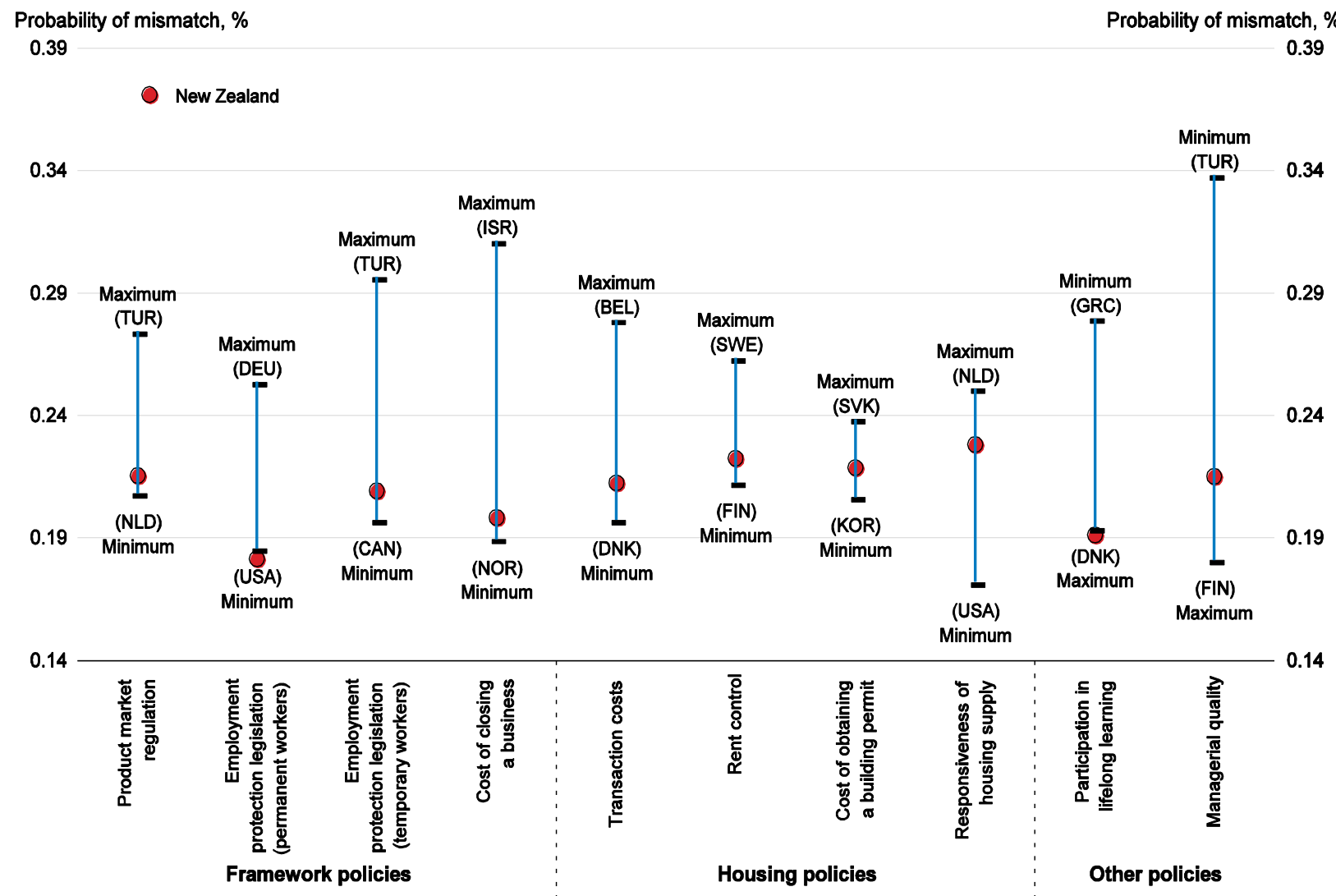

1. The red circle is the probability to have mismatch evaluated at the level of the policy in New Zealand and individual characteristics, which include age, marital and migrant status, gender, level of education, firm size, contract type, a dummy for working full-time and working in the private sector. The distance between the Min/Max and the red circle is the change in the probability of skills mismatch associated with the respective policy change.

Source: M. Adalet McGowan and D. Andrews (2017), "Skills Mismatch, Productivity and Policies in New Zealand: Evidence from PIAAC", OECD Economics Department Working Papers, No. 1403; OECD calculations based on the Survey of Adult Skills (PIAAC) (2012 and 2015).

If land-use policies were reformed and housing-related infrastructure provision stepped up such that the price elasticity of new housing supply increased to the best practice levels (found on average in the United States), NZ labour productivity could rise by $2 \frac{1}{4}$ per cent as a result of reduced mismatches 
(Figure 28). This is the largest impact of any policy area. It could also be worth considering what public policy can do efficiently to enhance matching without people having to move from their current location. The roll-out of high-speed broadband (fibre optic cable) in New Zealand is likely to increase possibilities for teleworking, potentially making for better matches without the need to move house (as well as helping workers, most often women, to better reconcile work and family responsibilities).

\section{Figure 28. Estimated gains to labour productivity from adopting best practice policies to reduce skills} mismatch 1

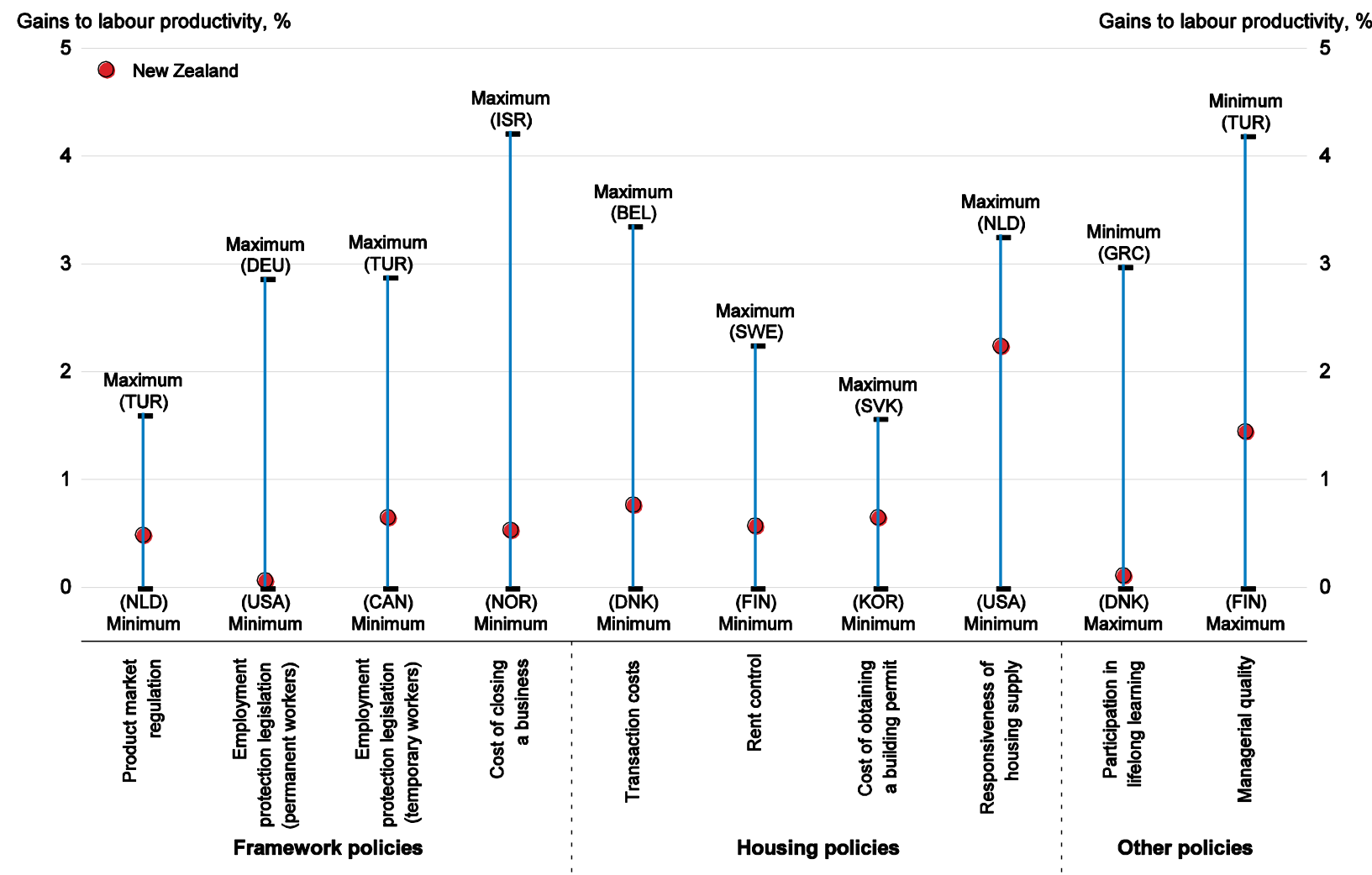

1. The red circle is the probability to have mismatch evaluated at the level of the policy in New Zealand and individual characteristics, which include age, marital and migrant status, gender, level of education, firm size, contract type, a dummy for working full-time and working in the private sector. The distance between the minimum/maximum and the red circle is the change in the probability of skills mismatch associated with the respective policy change. Estimates are based on logit regressions of probability of mismatch controlling for age, marital and migrant status, gender, level of education, firm size, contract type, a dummy for working full-time and working in the private sector and OLS regressions of labour productivity on skills mismatch.

Source: M. Adalet McGowan and D. Andrews (2017), "Skills Mismatch, Productivity and Policies in New Zealand: Evidence from PIAAC", OECD Economics Department Working Papers, No. 1403; OECD calculations based on the Survey of Adult Skills (PIAAC) (2012 and 2015).

Another factor that contributes to the determination of skills mismatch is management quality. Better managed firms may be less susceptible to mismatch by being more effective at: screening potential job applicants; developing new work practices to more effectively integrate new technologies; internally reallocating over-skilled/qualified workers to more productive uses within the firm; and/or taking remedial measures and/or removing under-skilled/qualified workers from the firm. Adalet McGowan and Andrews (2015b) find that better managerial quality, measured by managers' average literacy skills score, can account for the negative relationship between under-skilling and within-firm productivity, and that larger firms are more likely to be better managed, suggesting that under-skilling could be less likely in larger firms. While NZ managers have high literacy skills on average, they lag somewhat behind best practice 
(Finland). Increasing managers' literacy skills to best practice is estimated to increase productivity by $1 \frac{1}{2}$ per cent (Adalet McGowan and Andrews, 2017). Doing so would most likely entail attracting more highly-skilled people into management. This could be achieved by reducing impediments to the development of large firms, such as foreign direct investment restrictions, and barriers to competition, so that low-productivity poorly managed firms do not survive, releasing resources for better managed more productive firms. It should be borne in mind that managers' literacy skills are only a proxy for management quality, which depends on many other factors. It should be noted that the effects presented in Figure 28 cannot be cumulated as they reflect bivariate correlations rather than causal links.

\section{Helping displaced workers get back into work}

More rapid technological change may also increase the risk of workers being displaced, although there is no strong evidence of such changes having a greater effect in the New Zealand labour market now than in the past. In New Zealand the stock of displaced workers (i.e., those who report being displaced due to structural and technological change) is about $1.1 \%$ of the total workforce, which is comparable to the scale in other countries but higher than the pre-global financial crisis level (OECD, 2017b). However, the re-employment rate after two years is high $(84 \%)$, on a par with rates in the Nordic countries and higher than in many other OECD countries - concomitantly, only $0.18 \%$ of the workforce are displaced workers who have not been re-employed after two years. The share of displaced workers with low education attainment is much higher than the share of workers with low attainment in the population, as in other countries (ibid).

Although small in proportion to the overall workforce, the effects of displacement may be significant for some households. Displaced workers and their families in New Zealand bear the bulk of costs of being laid off. Average notice periods are short by international comparison, at around one week for blue collar workers, two weeks for white collar workers and one month for the $20 \%$ of workers covered by a collective agreement (Figure 29). This reduces costs for employers but leaves little time for dismissed workers to find a new job while still employed, which can harm their re-employment prospects by reducing the extent to which they can benefit from their professional network to find a new job and exposing them to the stigma that is sometimes attached to being unemployed. Only around one-half of displaced workers receive a redundancy payment from their employer, with an average payment equal to about 34 weeks of wages (Dixon and Maré, 2013; OECD, 2017b). This level and coverage of redundancy pay are comparable to those in other OECD countries but may lead to inequalities between workers as arrangements tend to be less favourable for low-skilled workers than for high-skilled workers.

Figure 29. The notice period for individual dismissals in New Zealand is among the shortest Notice period for individual dismissals in months, by type of contract, 2013

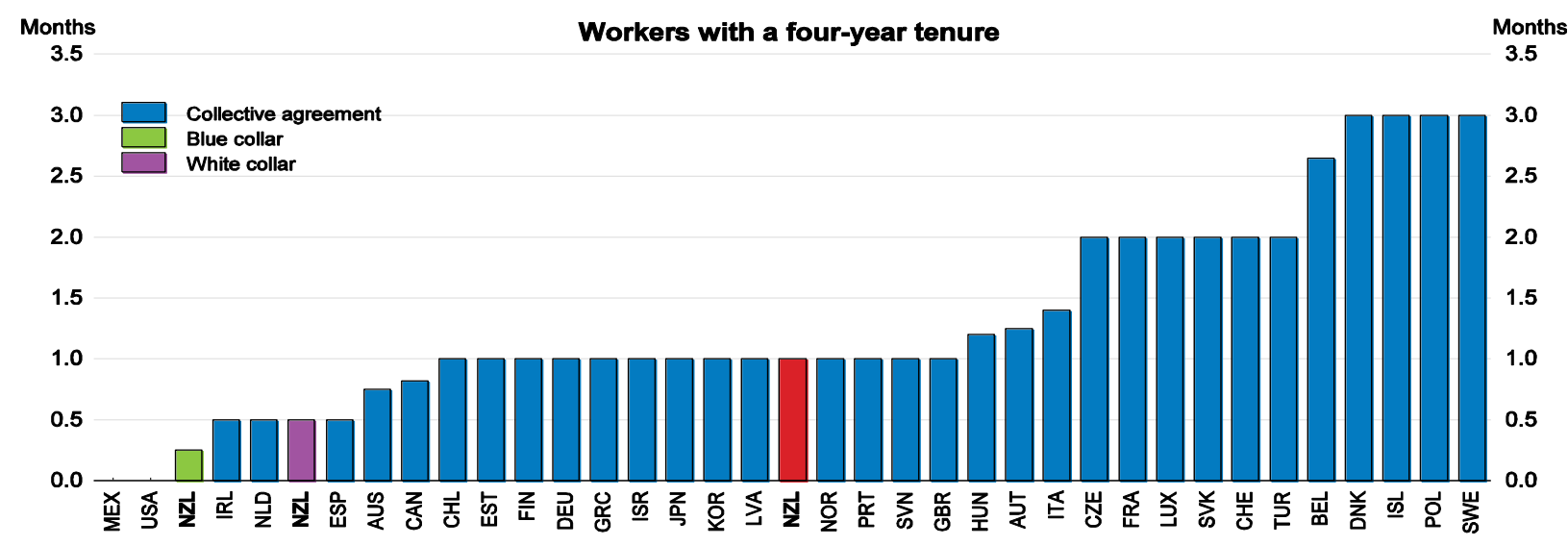

Source: OECD (2017), Back to Work: New Zealand - Improving the Re-employment Prospects of Displaced Workers, Figure 2.2. 
The biggest difference in comparison with most other countries is that there is no public unemployment insurance. Instead, New Zealand has a means-tested unemployment benefit, which few (30\%) displaced workers receive because most have household incomes that are too high (usually because they have a working partner). There are options for private unemployment insurance, but few workers are covered because it is expensive owing to information failures: as coverage is not compulsory, insurers suspect that only individuals with a relatively high risk of becoming unemployed will apply (adverse selection); and people with insurance may behave in ways that increase their claims (moral hazard). For those who do qualify for the benefit, net replacement rates initially tend to be below the OECD average but are higher after long periods of unemployment, when the unemployed in most other countries are no longer eligible for insurance benefits and instead receive lower (means-tested) social assistance benefits; for example, for a single-earner couple with two children previously earning the average wage the net replacement rate in New Zealand is 58\% compared with an OECD average that is initially $69 \%$ but falls to $55 \%$ for the long-term unemployed (OECD Tax-Benefit model). Moreover, the authorities generally do not assist displaced workers to find a new job unless they are eligible for social welfare benefits. With the exception of redundancy pay arrangements, which are comparable to those in other countries, all of the factors mentioned in this and the preceding paragraph contribute to displaced workers incurring larger earnings losses when re-employed than in most other OECD countries (OECD, 2017b): wage losses for reemployed dismissed workers in New Zealand are $12 \%$ in the first year, compared with negligible wage effects in Germany and the United Kingdom and around 6\% in the United States and Portugal. While on average these losses are offset by redundancy payments in the first year after job loss, the annual average income for displaced workers in New Zealand (including government income transfers and redundancy pay) is about $20 \%$ lower in the second and third year than for non-displaced workers with similar characteristics (Dixon and Maré, 2013). These factors may also contribute to the poor job matching observed in the labour market despite flexible labour market regulations, which improve matching.

As there is no mandatory notification requirement for redundancies, early intervention largely depends on voluntary initiatives of employers and employees. Local offices of Work and Income, New Zealand's public employment service, are often informed and involved ahead of large-scale redundancies, although this is ad hoc, and may respond proactively. However, this tends not to be the case for individual and multiple small-scale redundancies. Moreover, short notice periods make it difficult for Work and Income to organise the support needed for these workers to find a new job.

Few displaced workers contact Work and Income, at least shortly after losing their job. There may be a number of reasons for this, including that they are not eligible for income support because their household income exceeds the means-tested ceiling or that they are not looking for work. Work and Income's services are typically targeted at assisting disadvantaged jobseekers, with little to offer or any suitable vacancies for better-skilled displaced workers. Under the investment approach, Work and Income has no incentive to help workers not eligible for welfare benefits as doing so would entail costs but not generate any long-term savings on payments to current welfare beneficiaries.

A solution to reduce the burden on displaced workers would be to introduce public unemployment insurance, as in all other OECD countries except Australia and Mexico (excluding Mexico city, which has unemployment insurance), and expand the coverage of active labour market policies to those qualifying for unemployment insurance benefits to help this group to transition quickly to good (well-matched) new jobs. In most cases, this would just entail expanding the coverage of public employment services, such as enforcing job-search obligations, counselling and providing labour exchanges. In some cases, where individuals have greater difficulty finding a new job, it might entail active labour market programmes, such as training schemes or short-term employment subsidies. Such arrangements would help displaced workers search for better job matches than currently, both by giving them the wherewithal to prolong search to find a better job and providing them with services that facilitate job search and, where necessary, enhance their skills and employability, thereby reducing their earnings losses in re-employment. These arrangements 
would also preserve the advantages of flexible labour market regulations. As in other countries, unemployment insurance entitlements (to income-related benefits) would only be for a short period (e.g., 6-12 months, possibly towards the lower end of this range in normal times but towards the higher end during periods of high unemployment) for people with the necessary contributions record, after which time the unemployed would fall back on the current means-tested benefit. Under the investment approach, Work and Income would have an incentive to help displaced workers eligible for unemployment insurance benefits as their speedy re-employment would reduce fiscal outlays. Careful study would be required before embarking on such a reform to ensure that its design is such as to enhance social well-being, not reduce it. Ideally, unemployment insurance should be experience rated, so that it does not subsidise employers and industries with high lay-off rates at the expense of others.

If a public unemployment insurance scheme cannot be introduced in New Zealand, the next best solution to ease the financial burden on displaced workers and help them to transition to better jobs would be to introduce a minimum statutory notice period and mandatory notification of redundancies, as recommended in OECD (2017b). These reforms would reduce the loss of earnings for displaced workers and give them more time to search for a job while still in work. Work and Income would also have more time to organise support. At the same time, Work and Income's objectives could be expanded to include helping displaced workers not eligible for welfare benefits transition to a new job. The lack of appropriate services for skilled workers could also be addressed, including through more extensive collaboration with private employment services. The major drawback of mandatory notice periods is that they could reduce labour market turnover, which would adversely affect skill matching in the labour market. Careful study would be required before embarking on such a reform to ensure that it delivers more benefits than costs.

Careers advice and training guidance for adult workers, which is limited, also needs to be improved. Counselling would help people to understand which training options are best for them, helping to increase post-training employment rates. Rapidly changing skills needs in the economy require a continuous effort to guide adult workers to upskill and re-skill throughout their working lives (ibid). It would also be helpful to strengthen the framework for recognising skills acquired on the job before workers embark on new training.

\section{Getting the disabled into jobs}

To improve social integration of the disabled, general measures to increase education attainment and skills will need to be complemented by others directed specifically at people with disabilities and chronic health problems. The cornerstone of such measures should be to transform disability benefit (called "Supported Living Allowance" in New Zealand) into an employment instrument (OECD, 2010). Instead of assessing workers applying for the disability benefit on whether or not they can regularly work 15 hours or more per week in open (as opposed to sheltered) employment and granting a full benefit if they cannot, their remaining work capacity could be assessed, with partial benefits available subject to job-search requirements for beneficiaries with unused work capacity. A number of OECD countries have used partial disability benefits as a way to encourage people to remain in work or to return to some degree of employment. Most offer a full benefit for those more or less fully unable to work and various degrees of partial benefits in line with reduced work capacity. Incentives for the partially disabled to work can be sharpened further by making their benefit dependent on actually using their remaining work capacity, as in the Netherlands since 2006. In the current Dutch system workers with assessed earnings incapacity of 35$79 \%$ receive a wage supplement that depends on the amount of remaining work capacity actually used (at least half the actual remaining capacity needs to be used). If not working or not working enough, a flat-rate benefit is paid instead, which is considerably lower than the disability benefit used to be. Dutch reforms reduced the number of new disability benefit claims. However, the work-incentive features were not that effective for people with lower incomes, as the threat of a benefit cut was often effectively compensated by higher housing benefit entitlements (OECD, 2008). 
Such a reorientation of policy, even if it does not entail moving towards a unique working-age benefit, would need to be complemented by other measures to increase employment of the partially disabled. One approach to consider is to give employers greater incentives to retain sick employees. Employers are in a good position to judge what work their employees can still do and what work or workplace adjustments might be needed to accommodate the health problem that has arisen. Such early intervention could be facilitated with the assistance of an employment-oriented occupational health service, as in Finland, to help people with health issues get the help they need quickly, increasing their chances of remaining in employment (OECD, 2010). In the Netherlands, employers and their employees are now obliged to develop, follow and update a reintegration plan. Incentives could be strengthened by making employers responsible for paying sickness benefit for a longer period than currently, although such a measure would need to be balanced against the risk that employers may avoid hiring people with disabilities or health problems to reduce such costs. To limit these effects, employers would need compensation in some form (including through wage subsidies) for employing workers with reduced work capacity or productivity. These subsidies, which are common in Nordic countries, would need to be targeted at the lost work capacity of the worker and may be needed for a long period. Care would be needed, however, to limit moral hazard, especially in a system that allowed existing jobs to be transformed into subsidised jobs. Gatekeeping by doctors would also need to be refocused on assessing remaining work capacity.

Reorienting disability policy along these lines would entail putting much more emphasis on integration measures (Figure 30, Panel A) relative to compensation measures (Panel B), as in the Netherlands. The NZ government's "investment approach" could be used to help to identify clients for whom activation measures would be most valuable. It would be important to evaluate the effectiveness of measures. In addition, organisations providing activation programmes should be subject to performancebased contracts. 
Figure 30. Disability policy in OECD countries

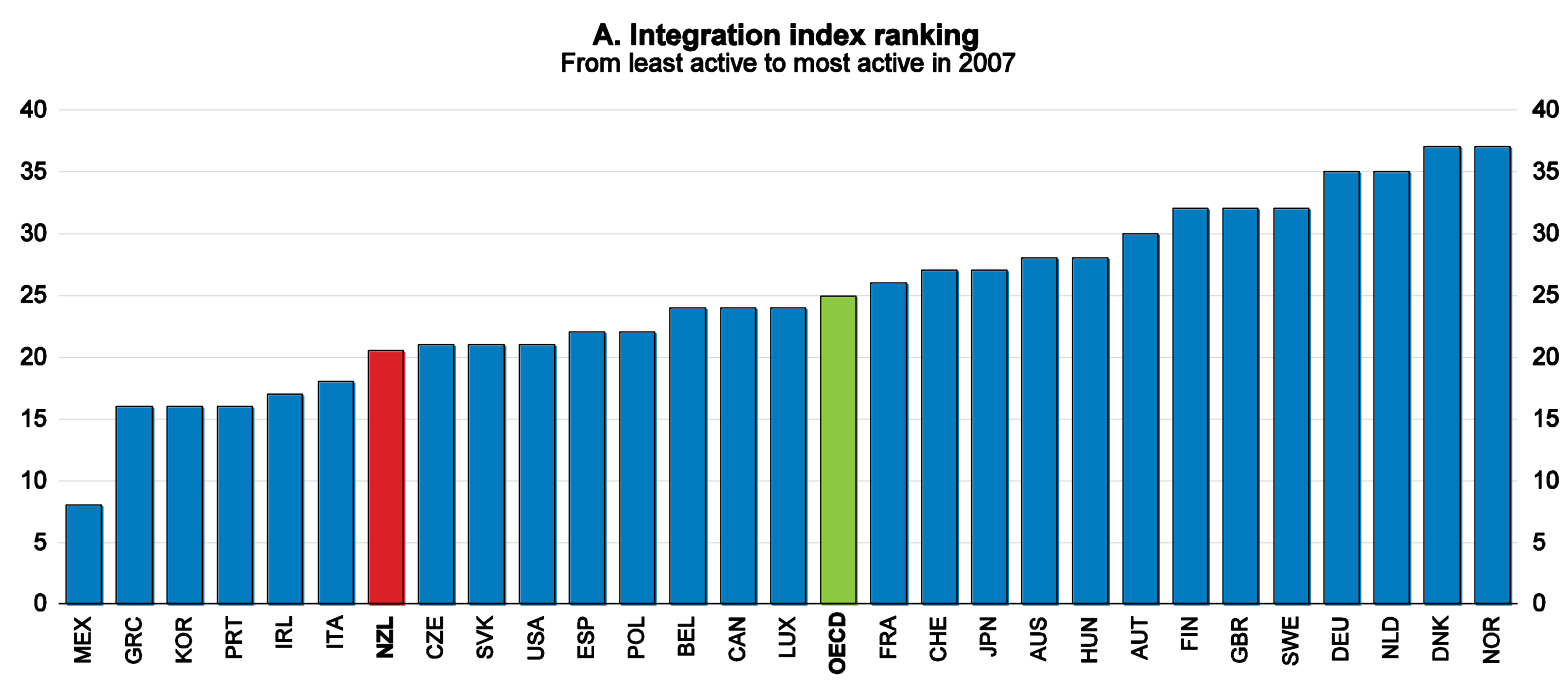

B. Compensation index ranking

From least generous to most generous in 2007

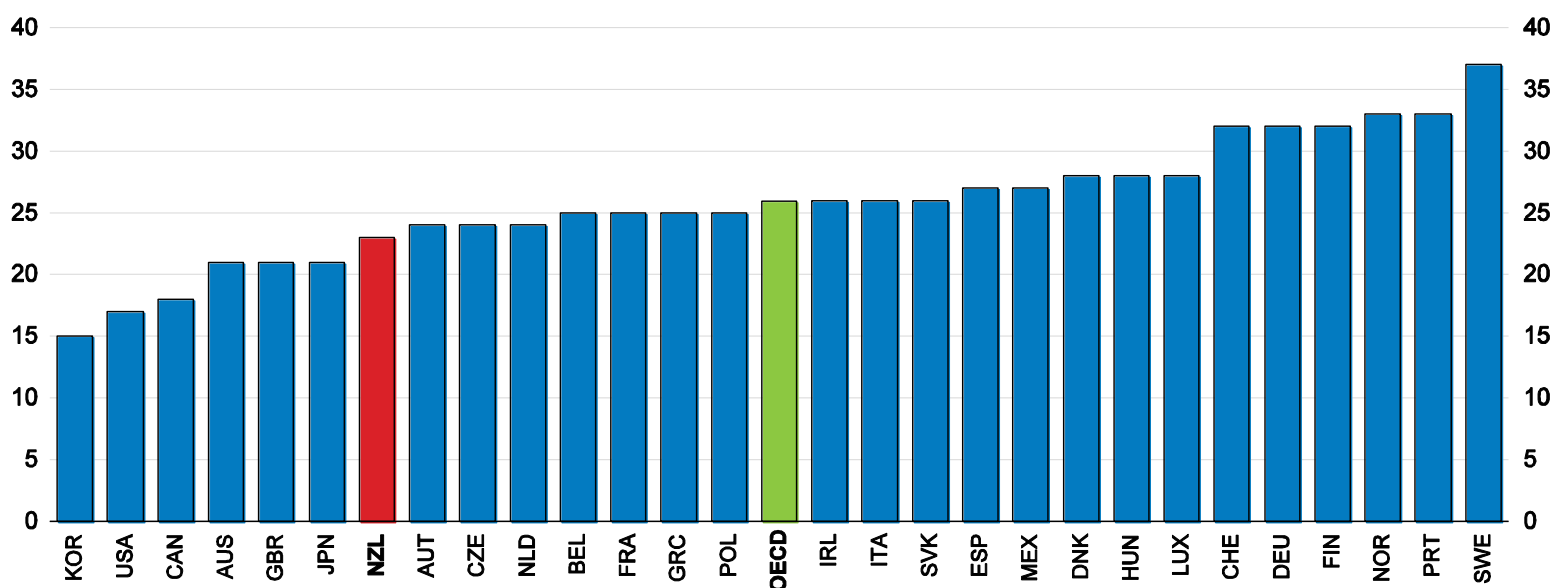

Source: OECD (2010), Sickness, Disability and Work - Breaking the Barriers, Figure 3.2.

\section{Further activating sole parents}

The activation measures taken in New Zealand to increase sole-parent employment rates are similar to those taken in other countries to achieve the same objective - subjecting sole parents to requirements to participate in employment services and labour market programmes when they have very young children (work preparation obligation for one-three years old), to search for at least a part-time job (at least 20 hours per week) when children are young (3-13 years old) and a full-time job when children are older (14 years or more). As noted above, active measures are taken to assist those who cannot get sustainable employment without further help. The child's age at which the parent is subject to work-availability and job-search requirements is lower in New Zealand than in the most culturally similar countries that undertook similar reforms (six in Australia and five in the United Kingdom) but higher than in Norway (one year), which has also reformed sole-parent benefits. Australia also reduced the rate at which benefits are withdrawn (known as benefit taper rates) to increase incentives to work, an option that should also be considered in New Zealand. An alternative approach is to set benefits so low that lone parents have to work to survive, as in Japan. This factor, together with preferential access to highly subsidised child care has resulted in Japan having almost the highest sole-parent employment rate in the OECD, with a very high 
proportion of sole parents working full time. "Unfortunately, the high lone-parent employment rate does not translate into low levels of child poverty, and many single mothers report that their lives, working full time with still relatively low net incomes, are difficult" (OECD, 2013, p. 150).

Part-time employment is considered to be the norm for sole parents with young children in New Zealand and a number of countries, including Australia, the United Kingdom, Ireland and the Netherlands. Accordingly, assistance is structured around this norm. However, in many European countries, full-time employment is considered to be the norm. If the NZ authorities wanted to move towards a full-time working model to increase sole parent incomes significantly, not only would the jobavailability and job-search requirements need to be amended, but also the very high marginal effective tax rates for working more than 20 hours per week faced by people on low incomes would need to be reduced, as discussed in the 2015 Survey. A sole parent taking up full-time, low-wage employment faced an effective tax rate of over $80 \%$ on the extra income in 2015, a third of which reflected additional childcare costs (Figure 31). These costs were higher than the OECD average for sole parents, accounting for New Zealand's higher overall effective tax rate. To encourage those on low incomes to work more than 20 hours per week, Working For Families abatement rates would need to be reduced as would childcare costs beyond 20 hours per week. The government took a step in this direction in April 2016, when it increased childcare assistance for low-income families from NZD 4 per hour to NZD 5 per hour for up to 50 hours per week for each child.

Figure 31. Effective tax rate for a sole parent moving to low-paid full-time work

Moving into full-time employment with earnings of $67 \%$ of average earnings, including childcare costs, $2015^{1}$

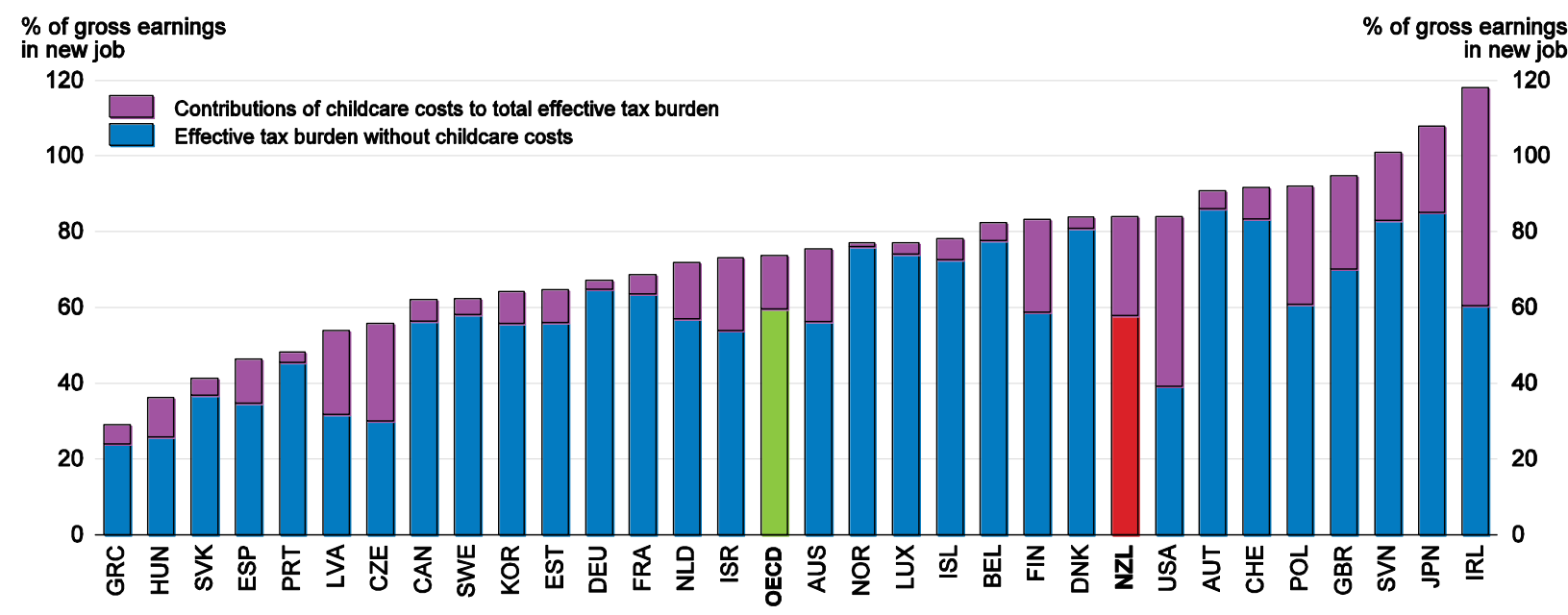

1. Effect of childcare costs for a sole parent with two children, aged two and three. 2012 data for Chile, Italy and Turkey.

Source: OECD, Tax-Benefit Models database, www.oecd.org/els/social/workincentives. 


\section{Recommendations to enhance adaptation to the changing labour market}

(Key recommendations are in bolded italics)

Upgrading skills

- Improve competence to teach mathematics by supporting professional development and evidenceinformed teaching and raising initial teacher education quality and entry standards.

- $\quad$ Review minimum numeracy requirements for school qualifications and the minimum education required by all school leavers. Help schools to make more effective use of ability grouping strategies.

- Merge Careers New Zealand into the Tertiary Education Commission, as the government has proposed, to increase the extent to which young people choose study fields in demand and tertiary institutions adapt their programmes to employer requirements.

Reducing skills mismatches

- Increase infrastructure investment needed to support better housing. Allow greater urban densification.

Adjusting to the development of non-standard work arrangements

- $\quad$ Collect more data on non-standard working arrangements.

- Consider how, if at all, laws and regulations governing the world of paid work should be adapted to manage the social and economic impacts of future changes in the scale and nature of non-standard working arrangements.

Helping displaced workers

- Consider introducing unemployment insurance or, alternatively, longer notice periods and mandatory notification of layoffs. Also consider expanding training, guidance and counselling for displaced workers.

Activating the disabled

- $\quad$ Transform disability benefit into an employment instrument by assessing eligibility on the basis of remaining work capacity and paying partial benefits to those with unused work capacity subject to satisfying job-search requirements.

- Reorient disability policy toward employment integration measures relative to compensation measures, as is occurring under the investment approach to social expenditures.

Activating sole parents

- $\quad$ Amend job-availability and -search requirements to move towards a full-time working model for sole parents that increases their incomes significantly, and reduce childcare costs for low-income people working more than 20 hours per week. 


\section{REFERENCES}

Adalet McGowan, M. and D. Andrews (2015a), "Labour Market Mismatch and Labour Productivity: Evidence from PIAAC Data", OECD Economics Department Working Papers, No. 1209, OECD Publishing, Paris.

Adalet McGowan, M. and D. Andrews (2015b), "Skill Mismatch and Public Policy in OECD Countries", OECD Economics Department Working Papers, No. 1210, OECD Publishing, Paris.

Adalet McGowan, M. and D. Andrews (2017), "Skill Mismatch, Productivity and Policies in New Zealand: Evidence from PIAAC", OECD Economic Department Working Papers, No. 1403, OECD Publishing, Paris.

Alton-Lee, A. (2003), Quality teaching for diverse students in schooling: Best evidence synthesis, Ministry of Education, Wellington, June.

Arntz, M., T. Gregory and U. Zierahn (2016), "The Risk of Automation for Jobs in OECD Countries: A Comparative Analysis", OECD Social, Employment and Migration Working Papers, No. 189, OECD Publishing, Paris.

Andrews, D., A. Caldera Sánchez and A. Johansson (2011), "Housing Markets and Structural Policies in OECD Countries", OECD Economics Department Working Papers, No. 836, OECD Publishing, Paris.

Auckland Co-Design Lab (2016), The Attitude Gap Challenge: A South Auckland Employment and Skills Challenge, Sponsored by the Ministry of Business, Innovation and Employment and the Ministry of Social Development.

Autor, D. (2015), "Why Are There Still So Many Jobs? The History and Future of Workplace Automation", Journal of Economic Perspectives, Vol. 29, No. 3, Summer, pp. 3-30.

Autor, D., F. Levy and R. Murnane (2003), "The Skill Content of Recent Technological Change: An Empirical Exploration”, Quarterly Journal of Economics, Vol. 118, No. 4, pp. 1279-1333.

Barker, A. (2017), “Improving Productivity in New Zealand's Economy”, OECD Economic Department Working Papers, No. 1419, OECD Publishing, Paris.

Bessen, J. (2016), "How Computer Automation Affects Occupations: Technology, Jobs, and Skills", Boston University Law and Economics Working Paper, No. 15-49.

Branch, G., E. Hanushek, and S. Rivkin (2012), "Estimating the Effect of Leaders on Public Sector Productivity: The Case of School Principals", NBER Working Paper, No. 17803, February.

Coase, R. (1937), “The Nature of the Firm,” Economica, Vol. 4, No. 16, pp. 386-405.

Deloitte (2015), From brawn to brains. The impact of technology on jobs in the UK, London.

Dixon, S. and D. Maré (2013), “The Costs of Involuntary Job Loss: Impacts on Workers' Employment and Earnings", Motu Working Paper 13-03, Motu Economic and Public Policy Research. 


\section{ECO/WKP(2017)52}

Farrell, D and F. Greig (2016), “The Online Platform Economy: Has growth peaked?”, JPMorgan Chase and Co. Institute, November, https://www.jpmorganchase.com/corporate/institute/document/jpmcinstitute-online-platform-econ-brief.pdf

Frey, C. and M. Osborne (2013), The Future of Employment: How Susceptible are Jobs to Computerization?, University of Oxford.

Giffi, C., B. Dollar, B. Gangula and M. Drew Rodriguez (2015), “American Manufacturing Competitiveness and the Looming Skills Gap", Deloitte Review, Issue 16, pp. 95-113.

Goodman, J., J. Melkers and A. Pallais (2016), “Can Online Delivery Increase Access to Education?”, NBER Working Paper, No. 22754.

Goos, M., A. Manning and A. Salomans (2014), "Explaining Job Polarization: Routine-Biased Technological Change and Offshoring", American Economic Review, Vol. 104, No. 8, pp. 2509-26.

Handel, M. (2012), "Trends in Job Skill Demands in OECD Countries", OECD Social, Employment and Migration Working Papers, No. 143, OECD Publishing, Paris.

Hanushek, E., G. Schwerdt, S. Wiederhold and L. Woessmann (2016), "Coping with Change: International Differences in the Returns to Skills", NBER Working Papers, No. 22657.

Hattie, J. (2008), Visible Learning: A Synthesis of Over 800 Meta-Analyses Relating to Achievement, Routledge, Oxford.

Holzer, H. (2015), “Job Market Polarization and U.S. Worker Skills: A Tale of Two Middles”, Economic Studies at Brookings, The Brookings Institution, April, Washington D.C.

Katz, L. and A. Krueger (2016), The Rise and Nature of Alternative Work Arrangements in the United States, 1995-2015“, NBER Working Paper, No. 22667.

Kennedy, J. (2016), Three Paths to Update Labor Law for the Gig Economy, Information Technology and Innovation Foundation, April.

ManpowerGroup (2016), Talent Shortage Survey.

Manyika J., S. Lund, J. Bughin, K. Robinson, J. Mischke and D. Mahajan (2016), Independent Work: Choice, Necessity, and the Gig Economy, McKinsey Global Institute.

Ministry of Education (2015), Education Counts, Ministry of Education, Wellington.

Montt, G. (2015), “The Causes and Consequences of Field-of-Study Mismatch: An Analysis using PIAAC", OECD Social, Employment and Migration Working Papers, No. 143, OECD Publishing, Paris.

Mullis, I., M. Martin, P. Foy and M. Hooper (2016), "TIMMS 2015 International Results in Mathematics", Retrieved from Boston College, TIMMS and PIRLS International Student center website: TIMSS 2015 and TIMSS Advanced 2015 International Results - TIMSS Reports

NZIER (New Zealand Institute of Economic Research) (2015), "Robot Nation? The Impact of Disruptive Technologies on Kiwis", NZIER Insight, 55-2015. 
NZPC (New Zealand Productivity Commission) (2017), New Models of Tertiary Education, Inquiry Report, Wellington.

OECD (2008), Sickness, Disability and Work: Breaking the Barriers. Vol. 3: Denmark, Finland, Ireland and the Netherlands, OECD Publishing, Paris. http://dx.doi.org/10.1787/9789264049826-en

OECD (2010), Sickness, Disability and Work: Breaking the Barriers. A Synthesis of Findings Across OECD Countries, OECD Publishing, Paris. http://dx.doi.org/10.1787/9789264088856-en

OECD (2013), OECD Employment Outlook, OECD Publishing, Paris. http://dx.doi.org/ 10.1787/empl_outlook-2013-en

OECD (2015a), OECD Economic Surveys: of New Zealand, OECD Publishing, Paris. http://dx.doi.org/ 10.1787/eco_surveys-nzl-2015-en

OECD (2015b), Education Policy Outlook 2015: Making Reforms Happen, OECD Publishing, Paris, http://dx.doi.org/10.1787/9789264225442-en

OECD (2016a), OECD Education at a Glance, OECD Indicators, OECD Publishing, Paris. http://dx.doi.org/10.1787/eag-2016-en

OECD (2016b), Skills Matter: Further Results from the Survey of Adult Skills, OECD Skills Studies, OECD Publishing, Paris. http://dx.doi.org/10.1787/9789264258051-en

OECD (2016c), OECD Employment Outlook, OECD Publishing, Paris. http://dx.doi.org/10.1787/19991266

OECD (2017a), Getting Skills Right: Financial Incentives for Steering Education and Training, OECD Publishing, Paris.

OECD (2017b), Back to Work New Zealand - Improving the Re-Employment Prospects of Displaced Workers, OECD Publishing, Paris.

Pont, B., D. Nusche and H. Moorman (2008), Improving School Leadership, Volume 1: Policy and Practice, OECD Publishing, Paris.

Robinson, V., M. Hohepa and C. Lloyd (2009), "School Leadership and Student Outcomes: Identifying What Works and Why", Best Evidence Synthesis Iteration [BES], Ministry of Education, New Zealand.

Schleicher, A. (ed.) (2016), Teaching Excellence through Professional Learning and Policy Reform: Lessons from around the World http://www.oecdilibrary.org/docserver/download/9116041e.pdf?expires $=1489745907 \& i d=i d \& a c c n a m e=0 c i d 840048$ 78\&checksum=59B951F68626D3D87801482D3A68BF72 